Florida International University

FIU Digital Commons

3-29-2019

\title{
Cost Benefit Analysis of Restocking the Threatened Caribbean Staghorn Coral on the Florida Reef Tract
}

Kevin Cavasos

kecavasos@gmail.com

Follow this and additional works at: https://digitalcommons.fiu.edu/etd

Part of the Agricultural and Resource Economics Commons, and the Environmental Studies Commons

\section{Recommended Citation}

Cavasos, Kevin, "Cost Benefit Analysis of Restocking the Threatened Caribbean Staghorn Coral on the Florida Reef Tract" (2019). FIU Electronic Theses and Dissertations. 3957.

https://digitalcommons.fiu.edu/etd/3957

This work is brought to you for free and open access by the University Graduate School at FIU Digital Commons. It has been accepted for inclusion in FIU Electronic Theses and Dissertations by an authorized administrator of FIU Digital Commons. For more information, please contact dcc@fiu.edu. 


\section{FLORIDA INTERNATIONAL UNIVERSITY}

Miami, Florida

\section{COST BENEFIT ANALYSIS OF RESTOCKING THE THREATENED CARIBBEAN STAGHORN CORAL ON THE FLORIDA REEF TRACT}

A dissertation submitted in partial fulfillment of

the requirements for the degree of

DOCTOR OF PHILOSOPHY

in

\section{EARTH SYSTEMS SCIENCE}

by

Kevin Cavasos

2019 
To: Dean Michael R. Heithaus

College of Arts, Sciences, and Education

This dissertation, written by Kevin Cavasos, and entitled Cost Benefit Analysis of Restocking the Threatened Caribbean Staghorn Coral on the Florida Reef Tract, having been approved in respect to style and intellectual content, is referred to you for judgment.

We have read this dissertation and recommend that it be approved.

Ligia Collado-Vides

$\begin{array}{r}\hline \text { Joel Heinen } \\ \hline \text { Pallab Mozumder }\end{array}$

Mahadev Bhat, Major Professor

Date of Defense: March 29, 2019

The dissertation of Kevin Cavasos is approved.

Dean Michael R. Heithaus

College of Arts, Sciences and Education

Andrés G. Gil

Vice President for Research and Economic Development and Dean of the University Graduate School

Florida International University, 2019 


\section{ACKNOWLEDGMENTS}

I would like to express my gratitude to Florida International University and department of Earth and Environment for their financial support and to the members of my committee: Dr. Mahadev Bhat, Dr. Ligia Collado Vides, Dr. Joel Heinen and Dr. Pallab Mozumder for their time, support, and feedback. I would especially like to recognize my Major Professor, Mahadev Bhat, for his extraordinary patience, insight and ability to provide perspective during challenging periods.

I would also like to thank my family, especially Amy and Ava, for their unwavering support and encouragement. Thank you for allowing my research to take precedent over just about everything for the past couple of years; you made achieving this milestone possible.

Thank you Allison Moulding and Tom Moore at NOAA, Diego Lirman at University of Miami, and Jessica Levy at the Coral Restoration Foundation for providing information and suggestions supporting critical components of our analysis.

Finally, I would like to thank Gail Excell for her willingness to consistently go above and beyond the call of duty to support the needs of the Earth and Environment department's graduate students.

This study was partially supported by a grant from the NOAA's National Centers for Coastal Ocean Science and Office of Ocean Exploration and Research (Grant NOAA NA11NOS4780045). 


\title{
ABSTRACT OF THE DISSERTATION \\ COST BENEFIT ANALYSIS OF RESTOCKING THE THREATENED CARIBBEAN \\ STAGHORN CORAL ON THE FLORIDA REEF TRACT
}

by

Kevin Cavasos

Florida International University, 2019

\author{
Miami, Florida \\ Professor Mahadev Bhat, Major Professor
}

Once a dominant structure building coral on shallow water reefs throughout the Caribbean and western Atlantic, staghorn coral (Acropora cervicornis) has experienced precipitous regional declines in abundance since the 1970s, the result of a multitude of interlinked natural and human-induced stressors. To mitigate declining trends and support the recovery of wild staghorn populations, a restocking program has been initiated to transplant tens of thousands of nursery-reared staghorn colonies annually onto reefs off SE Florida and throughout the Caribbean.

The objective of the present study is to examine the business case for a large-scale staghorn coral restocking program in the Florida Keys considering (1) one of the most important non-market functions of staghorn coral in the Florida Keys, support of commercial reef fish fisheries, and (2) the public's willingness-to-pay (WTP) to restock staghorn coral populations.

We develop a multi-stock fisheries bioeconomic model that incorporates the empirical relationship between staghorn coral abundance and commercially important reef fish carrying capacity on the FRT to quantify changes in optimal equilibrium reef fish 
stocks, harvest, and fishery profit from restocking staghorn coral populations under alternative fishery management regimes.

Using stated preference data elicited through a household survey of residents of the SE US, we estimate the public's willingness-to-pay (WTP) for enhanced staghorn abundance and ecosystem health on the Florida Reef Tract. We integrate psychometric measures characterizing the public's attitudes toward risk into an economic discrete choice model to examine the impact of individual risk characteristics on household WTP. Results of the survey confirm the public assigns substantial value to the recovery of staghorn coral populations and improved coastal ecosystem health on the Florida Reef Tract. Respondent WTP was strongly dependent on individual perceptions of the anthropogenic risks facing staghorn corals and local coral reef ecosystems. Bioeconomic model results suggest staghorn restocking could play an important role in the recovery of locally exploited reef fish stocks, although the incremental economic contribution to the fishery is substantially less than estimated annual WTP values. Benefit cost ratios range from .66 to 36.84 depending on the population of beneficiaries considered. 


\section{CONTENTS}

CHAPTER

PAGE

Chapter 1: Bioeconomic evaluation of staghorn coral supporting commercial reef fish

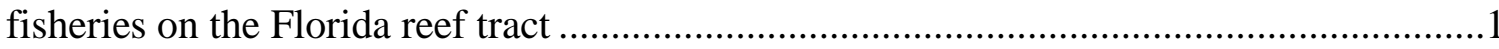

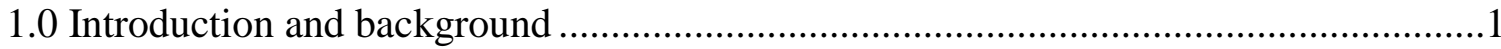

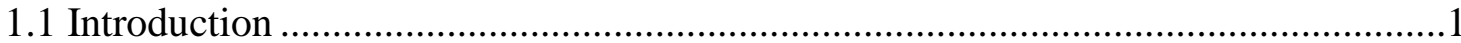

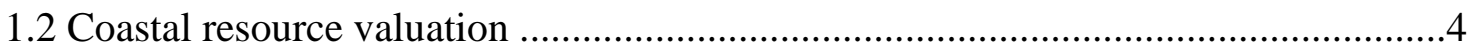

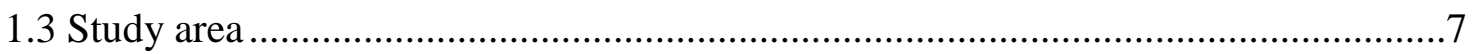

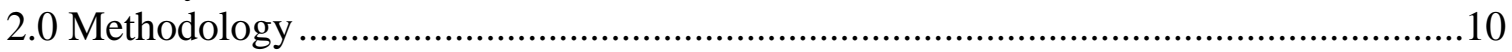

2.1 Bioeconomic model of coral-fishery linkages.....................................................10

2.2 Optimally managed single stock fishery ……….............................................12

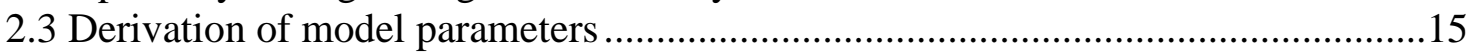

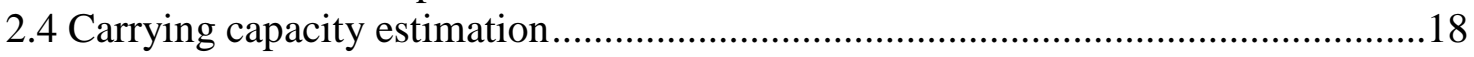

2.5 Simulating growth of outplanted corals and resulting changes in carrying capacity

2.6 Comparative static effects of a change in staghorn area .....................................20

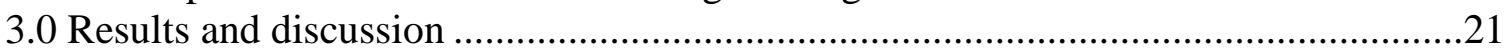

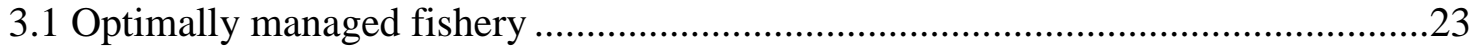

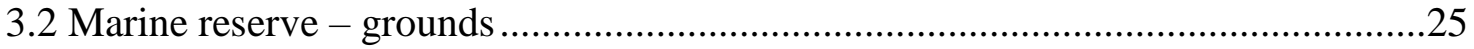

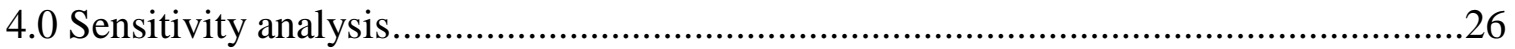

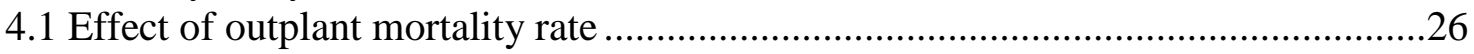

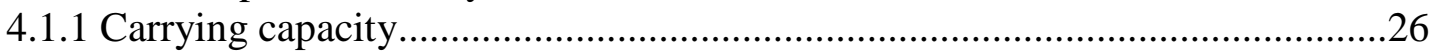

4.1.2 Fishery harvest and profit: marine reserve - grounds ......................................2

4.1.3 Fishery harvest and profit: optimally managed fishery ....................................27

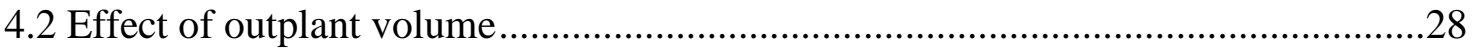

4.2.1 Carrying capacity.....................................................................................28

4.2.2 Fishery harvest and profit: marine reserve - grounds ......................................28

4.2.3 Fishery harvest and profit: optimally managed fishery ....................................29

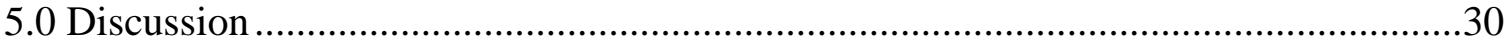

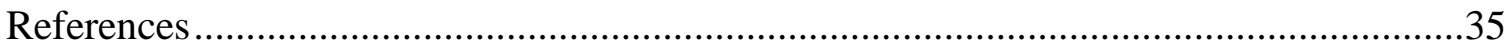

Chapter 2: Stated preference valuation of restocking and protecting the threatened

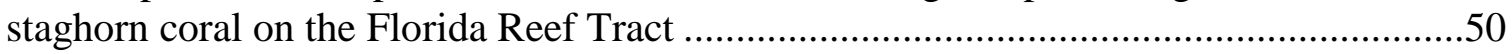

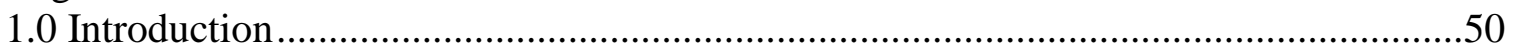

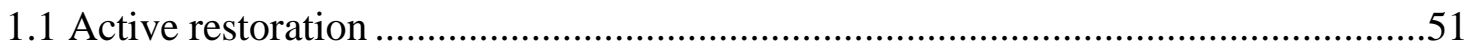

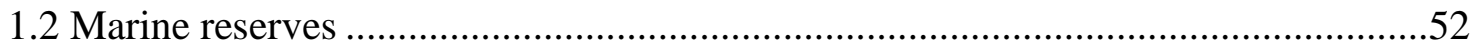

1.3 Estimating the benefits of restocking staghorn populations.....................................54

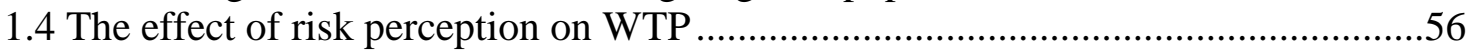

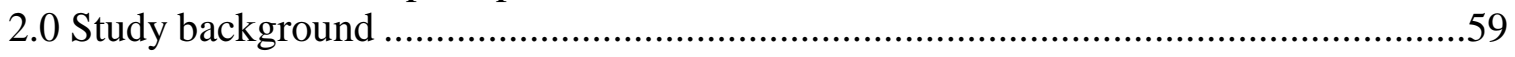

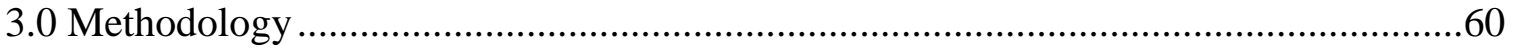

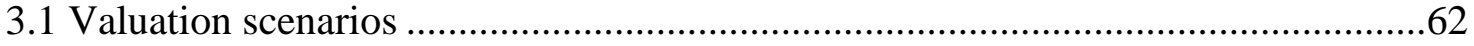




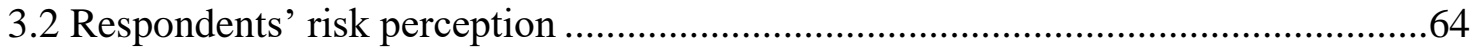

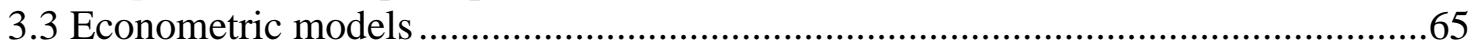

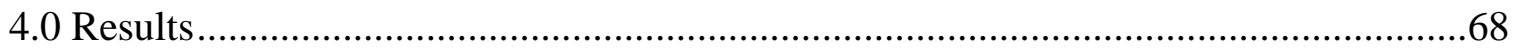

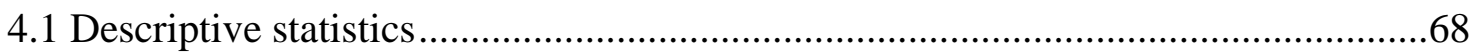

4.2 Rank ordered logit risk perception data and factor analysis results .........................69

4.3 Respondents' WTP and effect of risk perception..................................................

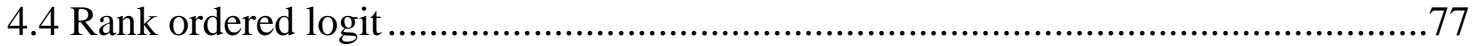

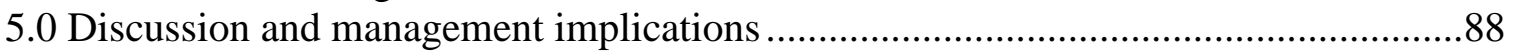

5.1 Nonmarket benefits from restocking and protecting staghorn corals .....................88

5.2 Implications for coastal resource management .....................................................89

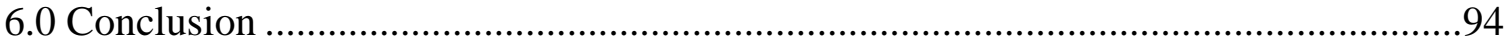

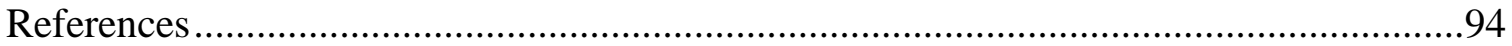

Chapter 3: Cost-benefit analysis of restocking staghorn coral on the Florida Reef ........108

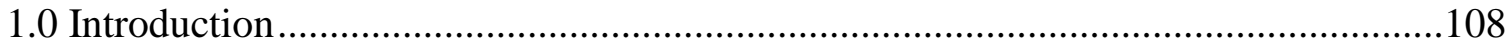

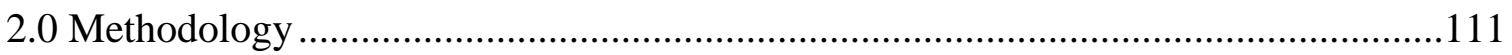

2.1 Theoretical Framework ...................................................................................111

2.2 Estimating changes to ES values from restocking and protecting staghorn corals 113

2.2.1 Recreational Diving Value .......................................................................113

2.2.2 Commercial reef-fish fishery value ..............................................................116

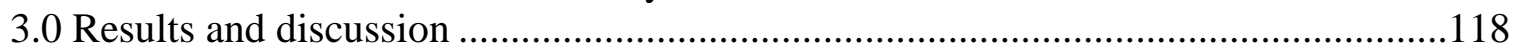

4.0 Management implications and conclusions ........................................................119

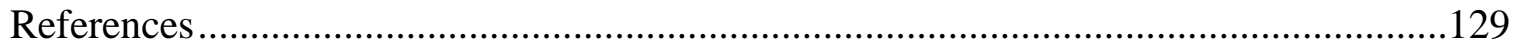

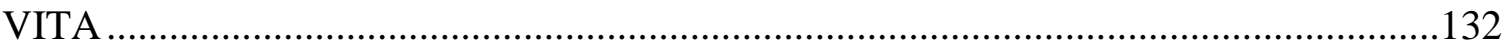




\section{LIST OF TABLES}

TABLE

PAGE

Table 1. Florida Keys commercial reef fish biomass and DRTO staghorn cover and

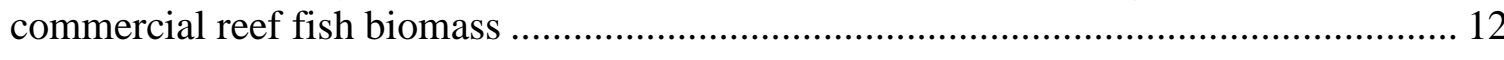

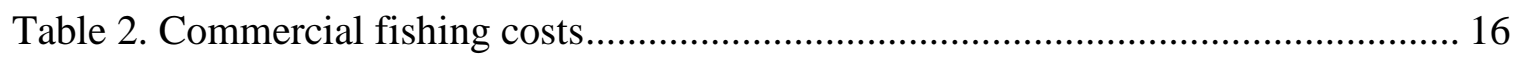

Table 3. Bioeconomic model parameters: optimally managed fishery.......................... 17

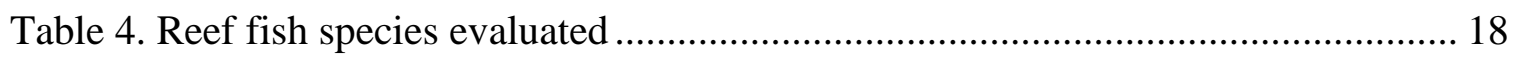

Table 5. Bioeconomic model parameters: marine reserve-fishing grounds configuration 18

Table 6. Regression results for staghorn coverage and reef fish biomass linkages ......... 21

Table 7. FRT reef fish biomass summary statistics .............................................. 22

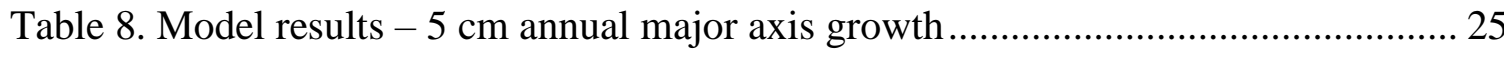

Table 9. Reserve-grounds model results with various mortality rates .......................... 27

Table 10. Results with various growth rates and outplanting intensities....................... 29

Table 11. Results with various growth rates and outplanting intensities....................... 30

Table 12. Alternative programs and outcomes ..................................................... 73

Table 13. Definition of variables included in the conditional logit model..................... 74

Table 14. Conditional logit respondent demographics ............................................ 75

Table 15. Summary of variables included in the final conditional logit model $(n=529) . .75$

Table 16. Results from conditional logit......................................................... 76

Table 17. Household WTP without distance as a covariate .......................................... 76

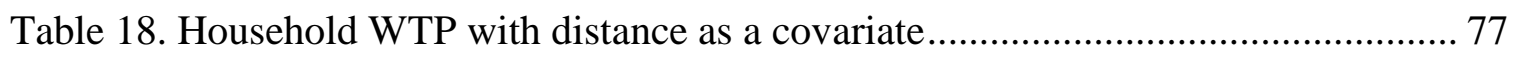

Table 19. Definition of variables included in the rank ordered logit model .................... 80 
Table 20. Rank ordered logit respondent demographics ......................................... 81

Table 21. Summary of variables included in rank ordered logit model $(n=530) \ldots \ldots \ldots \ldots . . .81$

Table 22. Risk perception, risk concern, and attitudes toward risk reduction ................. 82

Table 23. Risk perception, concern, and reduction preferences across demographic

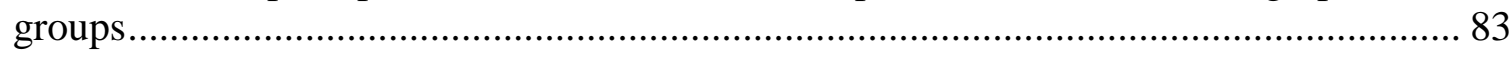

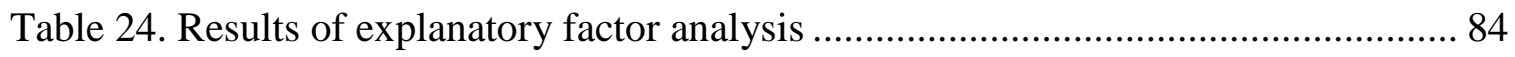

Table 25. Program cost combinations presented in survey ....................................... 85

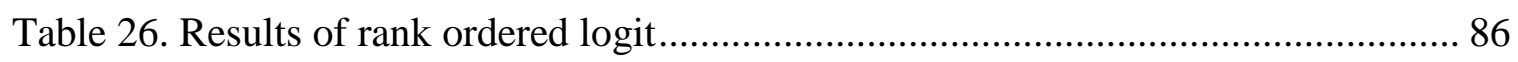

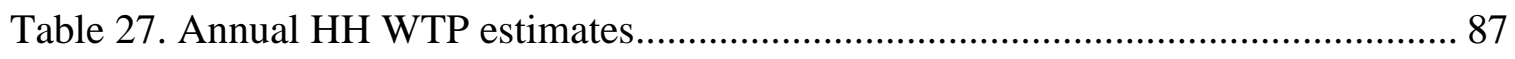

Table 28. Marginal WTP results at various levels of risk perception............................ 87

Table 29. Aggregated WTP for restocking and combined programs ............................ 87

Table 30. Staghorn coral contributions to communities of the Caribbean region .......... 125

Table 31. HH WTP for alternative programs estimated using rank-ordered logit.......... 125

Table 32. Bioeconomic model results: 5 ha treatment........................................... 125

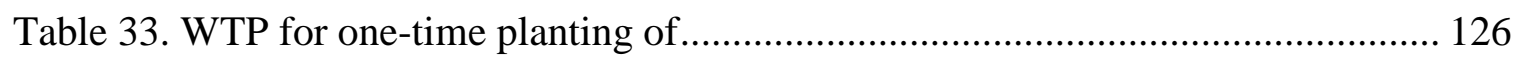

Table 34. Adjusted and unadjusted annual WTP ................................................... 127

Table 35. Discounted NPV for 5 hectares annually for 30 years aggregated to various

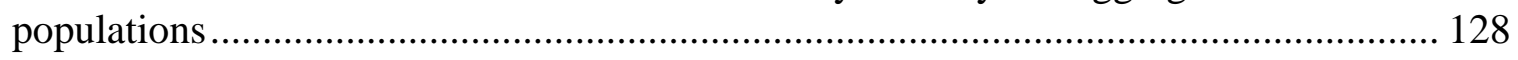

Table 36. Benefit-cost ratios: 5 hectares annually for 30 years .............................. 128 


\section{LIST OF FIGURES}

\section{FIGURE}

PAGE

Figure 1. Marine reserve - grounds configuration .............................................. 13

Figure 2. Staghorn coverage under alternative outplanting intensities ......................... 22

Figure 3. Fishery carrying capacity under alternative outplanting intensities ................ 22

Figure 4. Fishery harvest under alternative outplanting intensities ............................. 23

Figure 5. Fishery NPV - optimal fishery under alternative outplanting intensities ........ 24

Figure 6. Fishery harvest under alternative outplanting intensities ............................. 25

Figure 7. Fishery NPV with marine reserve under alternative outplanting intensities ..... 26

Figure 8. Adjusted. vs. unadjusted WTP ........................................................... 128 
Chapter 1: Bioeconomic evaluation of staghorn coral supporting commercial reef fish fisheries on the Florida reef tract

\subsection{Introduction and background}

\subsection{Introduction}

Coral reefs are some of the most productive and diverse ecosystems on earth, possessing extraordinary biological richness and providing food and resources to more than 500 million people in over 100 countries (Wilkinson, 2008). Estimates of coral reef cover range from only $0.1-0.5 \%$ of the ocean floor (Smith, 1978; Copper, 1994; Spalding and Grenfell, 1997), yet nearly one-third of the world's marine fish species are found on coral reefs (McAllister, 1991). Coral reefs can be found in shallow lagoons (platform reefs), along shorelines (fringing reefs), offshore (barrier reefs), and as isolated shallow areas in the open ocean (atolls), generally in areas of warm, clear, shallow, nutrient poor waters (Moberg and Folke, 1999).

Healthy coral reef ecosystems provide a multitude of goods and services of value to people. Coral reef related fisheries account for an estimated 10-13\% of the global fisheries catch (Munro and Williams, 1985), providing a variety of seafood products such as mussels, crustaceans, sea cucumbers and seaweeds (e.g., Craik et al., 1990; Birkeland, 1997) to millions of people. Pharmaceuticals and medical products have been derived from corals and reef dwelling organisms that include potential cures for cancer, arthritis, viruses, and other diseases (e.g., Sorokin, 1993; Carte', 1996; Birkeland, 1997). High numbers and diversity of marine species are drawn to the complex structure of coral reefs, supporting fisheries, tourism, recreation, educational and spiritual experiences 
(Wilkinson, 2008; Principe et al., 2012). The physical structure of coral reefs also provides physical coastal protection that can help mitigate coastal flooding, property damage and loss of life associated with large tropical storms (Sudmeier-Rieux et al., 2006; Goreau et al., 2012; Guannel et al., 2016).

The world's coral reefs are in peril, their natural resilience compromised by the cumulative effects of over-exploitation, pollution, habitat destruction, invasive species, disease, bleaching and global climate change (NMFS, 2015). In 2006, staghorn coral (Acropora cervicornis) and elkhorn corals (A. palmata) became the first marine invertebrates to be classified as 'threatened' under the US Endangered Species Act (NMFS, 2006). Twenty additional species of corals have been added to the list since that time, five of which occur in the Caribbean and 15 in the Indo-Pacific. More than half of the world's reefs are presently under medium or high risk of degradation (Burke et al., 2011), and research increasingly suggests that unavoidable climate change impacts makes corals' global extinction possible within decades.

Staghorn is a stony coral characterized by straight or slightly curved antler-like, cylindrical branches ranging from a few centimeters to over two meters in length (Gladfelter, 1983; Tunnicliffe, 1983). Studies of fossilized corals indicate the shallow fore-reef zones of the Caribbean region were once dominated by staghorn thickets (Pandolfi \& Jackson, 2006; Precht \& Aronson, 2006). The dominance of asexual reproduction through fragmentation in staghorn corals and limited larval dispersal have led to diminished effective population sizes and low genetic variation in regional populations, resulting in increased risk of disease (Bak, 1983). Since the 1970s, declines in the abundance of staghorn corals off Florida have been estimated as high as 97\% in 
some locations, primarily the result of white-band disease (Aronson and Precht, 2001), but linked to many inter-related natural and human induced stressors (NMFS, 2015). Impediments to the recovery of the species regionally include disease, increasing temperature, depensatory population effects, loss of recruitment habitat, sedimentation, natural and human caused abrasion and breakage, predation, inadequacy of existing regulatory mechanisms, ocean acidification, and nutrients and contaminants (Aronson and Precht, 2001; Bruckner, 2002; Hughes et al., 2003; NMFS, 2015). The widespread loss of the three-dimensional branching structure of staghorn corals from regional waters has dramatically reduced essential habitat and feeding, breeding, and spawning grounds for many economically important fish and invertebrates, likely impacting biodiversity and fisheries productivity and value.

Research suggests restocking staghorn colonies on denuded reefs may support the long-term recovery of wild populations and their genetic diversity (Lirman et al., 2014). A common propagation and restoration method, "coral gardening", entails extracting small amounts of tissue and skeleton from healthy wild coral colonies to propagate nursery stocks (in situ or ex situ) from which fragments can be pruned and transplanted to degraded reefs (Rinkevich, 1995, Bowden-Kerby, 2001; Epstein et al., 2001; Shafir and Rinkevich 2008; Shaish et al., 2008). Rapid growth rates and ability to reproduce through asexual propagation make staghorn coral well-suited for restocking projects (Highsmith, 1982; Lirman, 2010; NOAA, 2012). Multiple staghorn restocking projects have experienced high levels of success in the Caribbean and Florida Keys since the early 2000s (Schopmeyer et al, 2017). 
This research attempts to examine the economic efficiency of restocking denuded reefs with nursery-reared staghorn colonies by quantifying two of the most important non-market economic values impacted by active coral reef restoration: support of commercial reef fish fisheries and support of non-consumptive recreational coral reef uses like diving and snorkeling. In Chapter One of this paper we use an existing bioeconomic fishery model (Conrad, 1999), parameterized using locally collected fishery data (Miller and Huntington, 2015; SEFSC, 2016), to attempt to quantify the potential impact to the value of local commercial reef fish fisheries from efforts to restock staghorn coral populations. In Chapter Two we use two stated preference (SP) techniques to examine the public's willingness-to-pay to support staghorn coral populations off SE Florida. In Chapter Three we synthesize the findings from Chapters One and Two and, incorporating outplanting and monitoring cost data, derive the discounted net present value of the fishery and benefit-cost ratio under several hypothetical large-scale staghorn restocking scenarios.

\subsection{Coastal resource valuation}

Consideration of the economic values of goods and services flowing from marine resources is essential to decisions regarding their efficient use and allocation. Recognizing the universal importance of coral reefs, economists have spent several decades working to improve the reliability of estimates of their values. Early coral reef valuation studies tended to focus on direct-use values, like recreational snorkeling, diving, and fishing (e.g., Hundloe, 1990; Leeworthy, 1991; Leeworthy and Bowker, 1997; Johns et al., 2001; Cesar et al., 2002; Brander, 2006); Recent studies have 
attempted to estimate the changes in direct-use values of coral reefs or recreational destinations associated with proposed management decisions or policy changes (e.g., Cesar and Chong, 2002; Bhat, 2003; Bishop et al., 2011). Published estimates of the most important direct-use values exist for coral reef ecosystems in all US jurisdictions (Brander and van Beukering, 2013), however, the value of contributions from indirect uses, like essential habitat for commercially important fish stocks, are less common in the literature. Numerous studies have used mathematical simulation models to examine the bioeconomics of habitats supporting coastal fisheries (e.g., Lynne, et al., 1981; Bell, 1989; Bell, 1996; Barbier and Strand, 1997; Sathirathai, 1997; Barbier, 2000; Foley, et al., 2012). By quantifying biophysical connections between habitat quantity and/or quality and fishery productivity, these studies generally attempt to estimate changes in equilibrium stocks, effort, yield and /or profits under selected property rights regime(s), typically “open access", but commonly maximum sustainable yield (MSY) or maximum economic yield (MEY). Partitioning a simulated optimally managed fishery into a marine reserve (MR) and fishing grounds, Conrad (1999) compared optimal stocks, harvest and profits under various MR and fishing ground configurations. Lynne (1981) examined the role of marshlands of South Florida in supporting Gulf Coast fisheries by estimating the relationship between harvest, fishing effort, and marsh area. Bell (1996) estimated a fisheries production function to quantify the incremental value of saltwater marsh on recreational fish catch and consumer surplus. Findings suggest when considering the value of wetlands in supporting recreational fisheries, a state policy of purchasing and preserving coastal wetlands from development may be the most economically efficient. Modifying an open-access fisheries model to account for the effect of changes in 
mangrove area on equilibrium harvest and effort, Barbier and Strand (1997) demonstrate the detrimental effect of mangrove loss on the shrimp fishery of Campeche State, Mexico. Similarly, Sathirathai and Barbier (1997) used the Ellis-Fisher-Freeman model to estimate welfare effects of changes in mangrove area on Gulf of Thailand fisheries under open-access and managed fishery conditions.

The purpose of our study is to quantify the indirect economic and ecological benefits from coral reef restoration on the Florida Reef Tract (FRT). We develop a model that establishes a value for one of the non-market functions of staghorn corals, namely support of commercial fisheries, by exploring the empirical relationship between staghorn coral (Acropora cervicornis) abundance and commercially important reef fish carrying capacity on the FRT. This technique is consistent with previous efforts to examine the non-market benefits of natural systems (e.g., Lynne et al., 1981; Ellis et al., 1987; Barbier and Strand,1997; Loomis, 1998). We first simulate growth of coral colonies transplanted onto denuded reefs, then embed the abundance of outplanted coral as an environmental input into a multi-stock fishery bioeconomic model (Conrad, 1999) to enable comparison of changes in optimal equilibrium stocks, harvests, and fishery value from restocking under open-access and managed fishery regimes. To our knowledge, our study is the first empirical application of Conrad's (1999) model using fishery specific parameters and data and contributes to the existing ecological-economic literature by creating a framework for evaluating the commercial fishery benefits from restocking and protecting staghorn corals. 


\subsection{Study area}

The Florida Reef Tract (FRT) reaches approximately 220 miles southwest from Soldier Key off Miami to the Tortugas Banks in the Gulf of Mexico. About two-thirds of the FRT lies inside Biscayne National Park and the Florida Keys National Marine Sanctuary (FKNMS), a 2,900-square nautical mile $\left(\mathrm{NM}^{2}\right)$ marine protected area (MPA) that surrounds the Florida Keys. Proximity to the Miami metropolitan area and Florida Keys has subjected the reef ecosystem to decades of intense human use. Bruckner (2002) found mean staghorn coverage on the FRT to be $0.049 \%$ with little variation among the eight habitat types surveyed; Twenty- three of 35 species of groupers, snappers, hogfish, and grunts have been chronically over-fished since the 1970s according to National Marine Fishery Service (NMFS) standards (Ault, 1998). Partially in response to fishing pressure, 18 sanctuary preservation areas (SPA), totaling $1.45 \mathrm{NM}^{2}$, were established in 1997 in the FKNMS. The Tortugas Ecological Reserve (TER) was created as part of the FKNMS in 2001 to protect coral reef ecosystems and support reef fisheries. The TER protects $150 \mathrm{NM}^{2}$ prohibiting anchoring, fishing and other extractive activities bringing the aggregate area closed to all fishing in the Keys and Tortugas region to about $200 \mathrm{NM}^{2}$, $150 \mathrm{NM}^{2}$ in the TER, $35 \mathrm{NM}^{2}$ in the Research Natural Area in Dry Tortugas National Park, $9 \mathrm{NM}^{2}$ in Western Sambo Ecological Reserve, and $1.45 \mathrm{NM}^{\mathrm{S}}$ in the SPAs. Populations of several species of exploited reef fish, including black grouper, red grouper, and mutton snapper, have experienced dramatic increases in abundance since the TER was designated in 2001 (Ault et al., 1999), however, staghorn coral populations have shown little to no sign of natural recovery regionally. 
Staghorn coral, which can form large thickets two to three meters in height and 30 meters long (NMFS, 2015), was once a dominant coral in terms of structure accretion on shallow reef slope and fore reef environments in the Caribbean region. Staghorn historically occurred in SE Florida on the outer reef (Goldberg, 1973), spur-and-groove bank and transitional reefs (Jaap, 1984, Wheaton and Jaap, 1988), and consolidated hardbottom (Davis, 1982); Today, staghorn corals on the FRT exist primarily as isolated colonies or small thickets on shallow patch reefs (Miller et al., 2008). In 2006, staghorn coral became one of two marine invertebrates classified as 'threatened' on the US Endangered Species (ES) List (NMFS, 2006). Strategies identified to rebuild wild populations include restocking denuded reefs on the FRT with nursery-reared staghorn colonies and designation of "no-take" marine reserves to support outplanted colonies and restocked reefs (NMFS, 2015).

Changes in the structure and function of the coral reef ecosystems affect the life cycle and population dynamics of commercially harvestable reef fish species (Syms and Jones, 2000) and, thus, fishery productivity and value. Promoted as the "Fishing Capital of the World,", Florida is dependent on the health of its coastal resources to support sectors of the state's economy reliant on tourism and outdoor recreation. In 2012, the commercial fishing industry of East Florida supported over 82,000 jobs with landings of almost 13 million $\mathrm{kg}$ while the recreational fishing industry supported over 34,000 jobs and sales of over $\$ 4.0$ billion (NMFS, 2014). Over the same period as the precipitous decline in staghorn coral populations in SE Florida, mean annual commercial fishery landings off the east coast of Florida have fallen from over 37 million $\mathrm{kg}$ in 1980 to under 13 million $\mathrm{kg}$ for the period 2010-2016 (https://www.st.nmfs.noaa.gov). In our paper, 
using extensive field data collected in the Dry Tortugas National Park (DTNP) (Miller and Huntington, 2015) by the National Oceanic and Atmospheric Administration (NOAA), we try to quantify the relationship between staghorn coral coverage and the abundance of commercially important fish. With this empirical test, we aim to investigate whether staghorn restocking can benefit the commercial reef fishery and its economic bottom line in the Florida Keys.

Since the 1980s, federal agencies have been required to prepare analyses examining the economic efficiency of major policy decisions such as marine regulations and restorations. Currently, no published studies examine the long-range economic viability of restocking and protecting staghorn coral populations on the FRT. Our research estimates the ex-ante commercial reef fish fishery impacts of restocking staghorn corals under alternative outplanting intensities and fishery management / property rights regimes. Establishing a value for one of the primary non-market functions of restocked staghorn populations can inform cost-benefit analyses and support efforts by policy and decision makers to compare the potential benefits of alternative staghorn restoration projects and protection regimes, prioritize restoration and protection programs or projects, and maximize the ecological benefits per dollar spent. While reef protection supports a host of other non-market and market benefits (Moberg and Folke, 1999), valuing every one of them is beyond the scope of our paper.

Subsequent sections develop the theoretical and empirical methods used to examine the relationship between staghorn coral abundance and coral reef fish biomass. We first assume the fishery is managed for MEY, one-third (100 hectares (ha)) of which is restocked with staghorn corals. Next, we examine optimal equilibrium conditions 
under a marine reserve - fishing grounds configuration whereby the fishery is partitioned, and restocked reefs occupying one-third of the fishery are closed to consumptive uses. The biophysical effects of improved habitat from restocking enter our model through the carrying capacity in the reef fish stock growth function. The fishery impact of protecting restocked reefs enters through the intrinsic growth rate of the stock. We derive the stock and harvest levels achieving the optimal equilibrium of the fishery as well as the comparative static effects of restocking and protecting staghorn corals. We conclude by discussing the management implications of our findings, which we believe are relevant to economic analyses of current restocking efforts on the FRT as well as staghorn coral restoration efforts elsewhere.

\subsection{Methodology}

2.1 Bioeconomic model of coral-fishery linkages

Bioeconomic models generally integrate biological and economic factors to examine the potential impacts of management actions or variations in ecosystem inputs on the flow of goods and services supported by natural systems (Hanley and Barbier, 2009). Bioeconomic models have been used to examine the linkages between coastal fisheries production and habitats like marshlands, mangroves, and seagrass meadows (Lynne, 1981; Bell, 1989; Barbier and Strand, 1997; Bell, 1997; Kahui, Armstrong, and Vondolia, 2016). Conrad (1999) developed deterministic and stochastic models to examine optimal biomass levels, harvest rate, and fishery value under fishery management / property rights regimes. We modify Conrad's (1999) model to account for the effect of staghorn coral coverage on commercially harvestable reef fish biomass and 
productivity and quantify changes in the optimal equilibrium commercial reef fish stocks, harvest rate and profit from restocking and protecting staghorn coral populations. Because stocks of the most commercially harvested reef fish in Florida are managed, we first examine equilibrium conditions characterizing maximum economic yield (MEY) and the stocks which maximize net economic benefits to society, rather than that of an open access fishery. Following Barbier and Strand (1997), we simulate multiple scenarios to examine the comparative static effects of changes in staghorn area on equilibrium conditions. This approach is the first empirical and management application of multistock bioeconomic fisheries model linked with staghorn restocking on the FRT, and allows evaluation of alternative combinations of management actions, namely restoration and marine protection versus no action.

To estimate comparative static effects of restocking and protecting staghorn corals on equilibrium conditions, we examine changes in optimal commercial reef fish stocks and harvest from restocking staghorn coral under two fishery management regimes: 1) optimally managed fishery with no marine reserve, and; 2) fishery with marine reserve, i.e., fishing grounds, a portion of which is managed for MEY and the other portion as a no-take marine reserve. We first examine the model of the optimally managed fishery.

We use a dataset of reef fish and staghorn colony measures and abundance collected between 2012-2014 using underwater visual surveys ( $\mathrm{n}=65$ transects) in the Dry Tortugas National Park (Miller and Huntington, 2015), an area of relatively rich coral reef ecosystems, to estimate staghorn coverage, reef fish biomass, and quantify the relationship between the two. Using an observational dataset of reef fish measures inside and outside of no-take marine reserves in the FKNMS (SEFSC, 2016), we estimate mean 
reef fish biomass in the study area to be $213.98 \mathrm{~kg} \mathrm{ha}^{-1}$ and $134.51 \mathrm{~kg} \mathrm{ha}^{-1}$, respectively. We use these initial biomass values, with the estimated relationship between staghorn coverage and reef fish biomass, to estimate increases in biomass associated with enhanced staghorn cover from restocking.

Table 1. Florida Keys commercial reef fish biomass and DRTO staghorn cover and commercial reef fish biomass

\begin{tabular}{lcccc}
\hline Statistic & $\begin{array}{c}\text { FKNMS } \\
\text { protected } \\
\text { areas } \\
(\mathrm{n}=202 \\
\text { transects })\end{array}$ & $\begin{array}{c}\text { FKNMS } \\
\text { unprotected } \\
\text { areas } \\
(\mathrm{n}=595 \\
\text { transects })\end{array}$ & $\begin{array}{c}\text { Dry Tortugas } \\
\text { National } \\
\text { Park } \\
(\mathrm{DRTO}) \\
(\mathrm{n}=65\end{array}$ & $\begin{array}{c}\text { DRTO staghorn coral } \\
\text { cover }(\%)(\mathrm{n}=65 \\
\text { transects })\end{array}$ \\
\hline Mean & 335.79 & 230.63 & 1180.51 & \\
Median & 213.98 & 134.51 & 621.00 & 18.83 \\
Max. & 2452.35 & 5376.69 & 6202.39 & 7.23 \\
95 $5^{\text {th }}$ pct. & 1220.22 & 730.75 & 5142.13 & 54.66 \\
Std. dev. & 404.53 & 401.50 & 1636.46 & 20.16 \\
\hline
\end{tabular}

2.2 Optimally managed single stock fishery

Before examining the fishery partitioned into a marine reserve and fishing grounds, we first introduce a model of an optimally managed single-stock fishery whereby stocks and harvest are managed to maximize the economic yield of the fishery. Following Conrad (1999), biomass of commercially harvestable reef fish and harvest rate at instant $t$ are denoted $X=X(t)$ and $Y=Y(t)$, respectively. Suppose that $\pi(X, Y)$ is the annual net income from the commercial harvest $(Y)$, which increases at a decreasing rate with respect to stock and harvest. The annual growth of stock follows the equation of motion, $d X / d t=\dot{X}=F(X)-Y$, where $F(X)$ is a strictly concave net growth function. Applying the Maximum Principle, the stock size at the steady-state optimum must satisfy 
$F^{\prime}(X)+\pi_{X} / \pi_{Y}=\delta$ and $Y=F(X)$, where $\pi_{x}=\partial \pi(\cdot) / \partial X, \pi_{Y}=\partial \pi(\cdot) / \partial Y$, and $\delta$ is the discount rate (Clark, 1990). The steady state bioeconomic optimum is denoted $\left(X^{*}, Y^{*}\right)$. We model the optimally managed fishery such that $X=X^{*}$ and $Y^{*}=F\left(X^{*}\right)$.

If $\pi(X, Y)=(p-c / X) Y$ and $F(X)=r X(1-X / K)$, where $p>0$ is the unit price for fish on the dock, $c>0$ is a cost parameter, $r>0$ is the intrinsic fish stock growth rate the and $K>0$ its environmental carrying capacity, then the optimal equilibrium biomass level is

$X^{*}=\left[\frac{K}{4}\right]\left[\left(\frac{c}{p K}+1-\frac{\delta}{r}\right)+\sqrt{\left(\frac{c}{p K}+1-\frac{\delta}{r}\right)^{2}+\frac{8 c \delta}{p K r}}\right]$

and $Y^{*}=r X^{*}\left(1-X^{*} / K\right)$. The net present value (NPV) at the bioeconomic optimum is

$V\left(X^{*}\right)=\left(p-c / X^{*}\right) r X^{*}\left(1-X^{*} / K\right) / \delta$.

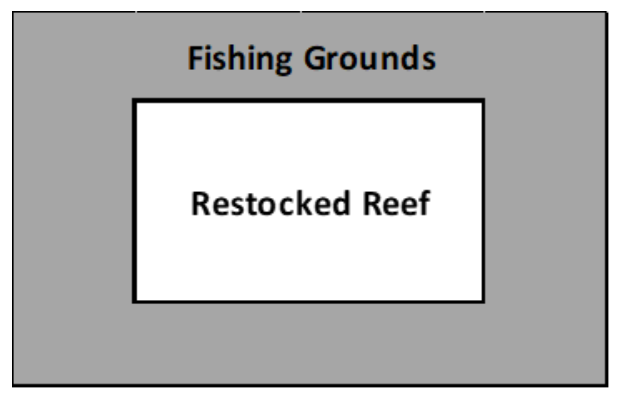

Figure 1. Marine reserve - grounds configuration

Now, we turn to two-stock model of reef-dependent commercial fishing whereby the economic yield of the fishery is maximized subject to partitioning the fishery into a marine reserve, which receives staghorn outplants, and a fishing ground which receives no staghorn outplants. Figure 1 represents our simulated fishery containing a coral reef restocked with nursery-reared staghorn corals. The purpose of the following model is to link fishery productivity on the fishing grounds to the restocking and protection of the 
reef. To enable comparison of equilibrium conditions between the two management regimes, we use a dynamic model of optimal fishery harvesting (Conrad, 1999). Formally, a management agency's objective is to maximize the present value net benefit of

$$
Z\left(K_{1}, K_{2}\right)=\int_{0}^{T} \pi\left(X_{1}, Y\right) e^{-\delta t} d t
$$

where $K_{1}$ and $K_{2}$ are the carrying capacities for commercially harvestable fish on the fishing grounds and in the marine reserve containing the restocked reef, $X_{1}$ and $X_{2}$ are the stocks on the fishing grounds and the marine reserves, respectively, and $Y$ is harvest from the grounds in period $t$ and is subject to a finite upper bound, $Y_{M A X}$, and a lower bound of zero. The underlying growth dynamics of the fish stock on the fishing grounds is assumed to follow:

$$
\dot{X}_{1}=F_{1}\left(X_{1}\right)+s\left(\frac{X_{2}}{K_{2}}-\frac{X_{1}}{K_{1}}\right)-Y
$$

where $F_{1}\left(X_{1}\right)$ is a density dependent logistic growth function, $s>0$ is a migration coefficient, and $X_{2}$ is the stock of harvestable fish in the reserve; and growth in the reserve:

$$
\dot{X}_{2}=F_{2}\left(X_{2}\right)-s\left(\frac{X_{2}}{K_{2}}-\frac{X_{1}}{K_{1}}\right), X_{1}(0) \text { and } X_{2}(0) \text { given } Y_{M A X} \geq Y \geq 0
$$

The population dynamics of commercially harvestable fish, $F_{i}\left(X_{i}\right)$, we simulate using the logistic function:

$$
r X(1-X / K)
$$

where $r>0$ is the intrinsic rate of growth for the fish stock. Because the fishing grounds receives no coral outplants, $K_{1}$ remains fixed over time; $K_{2}$ increases subject to the growth of outplanted corals. We assume restocking and protecting the reef results in 
migration of fish to the grounds from the reserve, expressed as a constant proportion of the difference in the pressures on the respective populations, $s\left(\frac{X_{2}}{K_{2}}-\frac{X_{1}}{K_{1}}\right)$, where $s>0$.

We compute the optimal stocks and harvesting paths to the above problem by solving the following current-value Hamiltonian (Conrad, 1999):

$\widetilde{H}=\pi\left(X_{1}, Y\right)+\mu_{1}\left[F_{1}\left(X_{1}\right)+s\left(\frac{X_{2}}{K_{2}}-\frac{X_{1}}{K_{1}}\right)-Y\right]+\mu_{2}\left[F_{2}\left(X_{2}\right)-s\left(\frac{X_{2}}{K_{2}}-\frac{X_{1}}{K_{1}}\right)\right]$,

where $\mu_{1}$ and $\mu_{2}$ are the current value shadow prices for reef fish on the grounds and in the reserve, respectively. Because we assume optimal management (and, thus, optimal fish stocks) prior to restocking, equilibrium harvest at $t=0$ is equivalent to the sum of net reef fish stock growth on the fishing grounds and in the sanctuary

$Y^{*}=r_{1} X_{1}\left(1-X_{1} / K_{1}\right)+r_{2} X_{2}\left(1-X_{2} / K_{2}\right)$

The optimal equilibrium fish stock on the grounds and in the reserve, $\left(X_{1}^{*}, X_{2}^{*}\right)$, must also satisfy

$$
F_{1}^{\prime}\left(X_{1}\right)+\frac{c\left[F_{1}\left(X_{1}\right)+F_{2}\left(X_{2}\right)\right]}{X_{1}^{2}\left(p-c / X_{1}\right)}+\left[\frac{s^{2}}{K_{1} K_{2}\left[\delta-F_{2}^{\prime}\left(X_{2}\right)+s / K_{2}\right]}\right]-\frac{s}{K_{1}}-\delta=0
$$

equivalent to requiring that the reef fish stock earn a rate of return commensurate with that which could be earned elsewhere in the economy, $\delta$ (Conrad, 1999). Using ex-ante estimates of outplanted staghorn coverage, reef fish fishery carrying capacity, market fish prices, and parameters derived from peer reviewed literature, our model enables characterization of the linkages between staghorn outplanting and protection, and commercial reef fish stocks and optimal sustainable harvest.

\subsection{Derivation of model parameters}

The cost parameter, $c$, was derived from a National Marine Fisheries Service (NMFS) survey of commercial vessels in the Gulf of Mexico (NMFS, 2016). From the NMFS 
fisher survey dataset, we calculate total variable and fixed costs to be $60.3 \%$ of revenue (Table 2). This is equivalent to the expression $\frac{c}{X}=.603 * p$, where $c / X$ is the unit cost of harvest and $p$ denotes market price. Rearranging terms, we solve for $c$, total cost of harvest: $c=.603 * p * X$. Using the market price of $\$ 5.87 \mathrm{~kg}^{-1}$ and median reef fish abundance in unprotected areas estimated from the SEFSC (2016) datasets (134.51 $\mathrm{kg} \mathrm{ha}^{-}$ ${ }^{1}$ ) multiplied by the size of the grounds (200 ha), we calculate total harvests costs to be $\$ 95,222$. We assume commercial vessels are owner operated, therefore, captain pay is embedded in boat profit rather than presented as a percentage of total costs.

Table 2. Commercial fishing costs

\begin{tabular}{ll}
\hline Expense & $\begin{array}{l}\text { \% of } \\
\text { revenue }\end{array}$ \\
\hline Fuel & 11.8 \\
Bait & 8.30 \\
Ice & 2.40 \\
Groceries & 3.50 \\
Miscellaneous & 2.50 \\
Tackle & 2.80 \\
Captain Pay & 0.00 \\
Crew Pay & 19.1 \\
Overhead (assumed) & 10.0 \\
Total variable and fixed costs & 60.3 \\
\hline Source: NMFS (2016)
\end{tabular}

Per kilogram fish price on the dock, $p$, was taken from NMFS landing data collected from 2012-2014. The rate of discount of 4\% is the mean 10-year US Treasury note yield since 1997 (3.9\%), rounded up to the nearest whole number; discount rates of $2 \%-6 \%$ are commonly used in the literature. The fish stock growth rates on the grounds and in the reserve, $r_{1}$ and $r_{2}$, respectively, in the reserve - grounds configuration were taken from www.fishbase.org (Froese and Pauly, 2018). In the bioeconomic literature, 
biophysical effects of habitat change typically enter the model through the stock growth function (Barbier, 2000; Foley, et al., 2012). To account for improved habitat and increased fishery productivity from protecting restocked colonies, the reef fish stock growth function in our model is greater inside the reserve than outside the reserve in the marine reserve - grounds configuration. The migration coefficient, $s>0$, presumes fish move from the reserve to the grounds in search of more plentiful food or less congested habitat and is estimated to be $10 \%$ of the carrying capacity of the fishery (Conrad, 1999). Because movement of fish in and out of marine reserves is difficult to track reliably and limited data exists, estimation of spillover effects is challenging. Our estimate follows Conrad's (1999) diffusion coefficient of approximately $10 \%$ of the carrying capacity of the fishery, however, ours is an educated guess and may under or over represent the actual diffusion of fish from the marine reserve onto the grounds.

Table 3. Bioeconomic model parameters: optimally managed fishery

\begin{tabular}{cllll}
\hline & & \multicolumn{3}{c}{ Annual Outplants } \\
Parameters & Description & 50,000 & 40,000 & 30,000 \\
\hline$c$ & Annual harvest cost & 190,452 & 152,360 & 114,270 \\
$\delta$ & Discount Rate & 0.04 & 0.04 & 0.04 \\
$p$ & Unit price fish at dock $(\$ / \mathrm{kg})$ & 5.87 & 5.87 & 5.87 \\
$r$ & Intrinsic growth rate on grounds & 0.20 & 0.20 & 0.20 \\
$K$ & Fishery carrying capacity & 64,194 & 51,355 & 38,516 \\
& Fishery size (ha) & 300 & 240 & 180 \\
\hline
\end{tabular}


Table 4. Reef fish species evaluated

\begin{tabular}{ll}
\hline Common Name & Scientific Name \\
\hline White Grunt & Haemulon plumierii \\
Bluestripe Grunt & Haemulon sciurus \\
Red Grouper & Epinephelus morio \\
Black Grouper & Mycteroperca bonaci \\
Yellowtail & Ocyurus chrysurus \\
Gray Snapper & Lutjanus griseus \\
Mutton Snapper & Lutjanus analis \\
Hogfish & Lachnolaimus \\
\hline
\end{tabular}

Table 5. Bioeconomic model parameters: marine reserve-fishing grounds configuration

\begin{tabular}{clccc}
\hline & & \multicolumn{3}{c}{ Outplant number } \\
Parameters & Description & 50,000 & 40,000 & 30,000 \\
\hline$c$ & Annual harvest cost & 95,226 & 76,180 & 57,135 \\
$\delta$ & Discount rate & 0.04 & 0.04 & 0.04 \\
$p$ & Unit fish price at dock $(\$ / \mathrm{kg})$ & 5.87 & 5.87 & 5.87 \\
$r_{1}$ & Intrinsic growth on grounds & 0.20 & 0.20 & 0.20 \\
$r_{2}$ & Intrinsic growth in reserve & 0.30 & 0.30 & 0.30 \\
$K_{1}($ constant $)$ & Carrying capacity grounds & 42,797 & 34,237 & 25,678 \\
$K_{2}$ & Carrying capacity reserve & 21,398 & 17,119 & 12,839 \\
$s$ & Spillover coefficient & 6,419 & 5,136 & 3,852 \\
& Grounds size (ha) & 200 & 160 & 120 \\
& Reserve size (ha) & 100 & 80 & 60 \\
\hline
\end{tabular}

\subsection{Carrying capacity estimation}

We use median reef fish density in FRT marine reserves estimated from the SEFSC (2016) dataset to derive fishery carrying capacity $\left(\mathrm{kg} \mathrm{ha}^{-1}\right)$. We converted length - weight observations ( $n=202$ transects) for eight species of commercially harvestable groupers, snappers, and grunts (Table 4) to biomass using the equation: $W=\alpha L^{b}$ where $W$ is the weight (gm), $L$ is the length to fork (cm), and $\alpha$ and $b$ are parameters estimated by linear regression of logarithmically transformed length-weight data (Bohnsack and 
Harper, 1988). Marine reserve and fishing ground carrying capacity at $t=0$ are calculated as the product of the median biomass from the SEFSC (2016) dataset (213.98 $\mathrm{kg} \mathrm{ha}^{-1}$ ) and the number of hectares in the respective area:

Marine reserve carrying capacity $=213 \mathrm{~kg} \mathrm{ha}^{-1} * 100 \mathrm{ha}=21,398 \mathrm{~kg}$

Fishing grounds carrying capacity $=213 \mathrm{~kg} \mathrm{ha}^{-1} * 200 \mathrm{ha}=42,796 \mathrm{~kg}$

2.5 Simulating growth of outplanted corals and resulting changes in carrying capacity At the time of outplanting, simulated colonies are presumed elliptical in shape, 25 $\mathrm{cm}$ in length. We simulate changes in coverage of outplanted staghorn colonies following the equation for the area of an ellipse

Area $=\pi A B$

where $A$ and $B$ are one-half the length and width of the colonies' major and minor axis, respectively (Kiel, 2014).

From the Miller and Huntington (2015) dataset, the sum of the length, width, and height, or total linear length $(T L L)$, at outplanting was imputed

OutplantTLL $=\frac{25}{(L / T L L)_{\text {mean }}}$

where 25 is the major axis length and $(L / T L L)_{\text {mean }}$ is calculated

$(L / T L L)_{\text {mean }}=\frac{1}{951} \sum_{i=1}^{951} L_{i} /\left(L_{i}+W_{i}+H_{i}\right)$

where $T L L$ is $L_{i}, W_{i}, H_{i}$ are the length, width, and height, respectively, of the $i^{t h}$ colony.

Outplant width at $t=0$ is calculated

outplant width $=W / T L L_{\text {mean }} *$ OutplantTLL

where $W$ is colony outplanted colony width, $T L L_{\text {mean }}$ is the mean sum of colony length, width, and height calculated from the sample. Simulated outplants are spaced one meter 
apart $(10,000$ per hectare (ha)) to increase the potential for cross fertilization of gametes (Johnson et al., 2011). We examine treatments of three, four and five hectares and major axis growth rates of three, four, and five $\mathrm{cm} \mathrm{yr}^{-1}$. Our baseline results examine treatments of five ha and an annual growth rate of five $\mathrm{cm}$. We cap colony length at $100 \mathrm{~cm}$ (at which point colonies in the interior of the treatment will meet and begin to interlock) and cap coverage to $54.31 \%$ of the treatment area, which is found to be approximately equal to the 95th percentile coral coverage estimated from the Miller and Huntington (2015) dataset. Simulated outplants in the baseline scenario experience first-and-second year mortality of $15 \%$ and $10 \%$, respectively, and none thereafter (Schopmeyer et al, 2017). An additional scenario was examined with first-and-second year outplant mortality of $15 \%$ and $10 \%$, respectively, and 6\% annual die offs in total staghorn area in years 3-20 (Goergen et al., 2019).

2.6 Comparative static effects of a change in staghorn area

We quantify the incremental contribution of staghorn coverage to commercial reef fish carrying capacity by regressing the logarithm of reef fish density on staghorn percent coverage estimated from the Miller and Huntington $r(2015)$ dataset $\left(R^{2}=.7163\right)$

lnFish $=\beta_{0}+\beta_{1}$ lnCoral $+\beta_{2}$ GruntDummy $+\beta_{3}$ GrouperDummy + $\beta_{4}$ SnapperDummy

Dummy variables indicating the dominant fish group in each transect were used to enable examination of individual species effects and characterize the composition of the "average" transect. Reef fish carrying capacity in the restocked area/marine reserve, $K_{2}$, in periods 1-20 is calculated

$$
\text { Biomass }_{t}=\text { Biomass }_{t-1}+\left(1+\beta_{1}\right) *\left(\text { Coral }_{t}-\text { Coral }_{t-1}\right)
$$


where Biomass $_{t}$ is commercially harvestable reef fish carrying capacity $\left(\mathrm{kg} \mathrm{ha}^{-1}\right)$; Because no restocking takes place on the fishing grounds with the marine reserve fishing grounds configuration, its carrying capacity, $K_{1}$, remains fixed at the $t=0$ level of $213.98 \mathrm{~kg} \mathrm{ha}^{-1}$ (equation 11).

Table 6. Regression results for staghorn coverage and reef fish biomass linkages

\begin{tabular}{lcccc}
\hline \multicolumn{1}{c}{ Variable } & $\begin{array}{c}\text { Parameter } \\
\text { estimate }\end{array}$ & $\begin{array}{c}\text { Standard } \\
\text { error }\end{array}$ & $\begin{array}{c}\mathrm{T}- \\
\text { statistic }\end{array}$ & Prob>(T) \\
\hline Intercept & -6.421 & 0.8907 & -7.2087 & $1.10 \mathrm{e}-09$ \\
Coral coverage (\%) & 0.0643 & 0.0218 & 2.9502 & 0.0045 \\
Grunt dummy & 9.7037 & 1.1515 & 8.4273 & $9.18 \mathrm{e}-12$ \\
Grouper dummy & 12.6313 & 1.4320 & 8.8209 & $1.98 \mathrm{e}-12$ \\
Snapper dummy & 11.1385 & 1.3752 & 8.0996 & $3.31 \mathrm{e}-11$ \\
\hline
\end{tabular}

\subsection{Results and discussion}

Our baseline scenario consists of 50,000 staghorn outplants growing at a rate of $5 \mathrm{~cm} \mathrm{yr}^{-1}$ with first and second year mortality of $15 \%$ and $10 \%$, respectively; we also examined a scenario consisting of first and second year outplant mortality of $15 \%$ and $10 \%$, respectively, plus $6 \%$ annual loss in aggregate outplant cover for years $3-20$. In the baseline scenario, restocking increases fishery carrying capacity by $158.72 \%$ from 213.98 $\mathrm{kg} \mathrm{ha}^{-1}$ in year 0 to $553.58 \mathrm{~kg} \mathrm{ha}^{-1}$ in year 20 . Depending on management regime, restocking increases optimal annual harvest between $45.50 \%$ (optimal fishery) and $82.99 \%$ (reserve) and fishery value between $13.05 \%$ (optimal fishery) and $67.79 \%$ (reserve). The presence of the marine reserve increases total harvest by $22.75 \%$ and fishery NPV by $50.90 \%$ from the optimal fishery. 
Table 7. FRT reef fish biomass summary statistics

\begin{tabular}{|c|c|c|}
\hline & $\begin{array}{l}\text { Unprotected } \\
\text { biomass }\left(\mathrm{kg} \mathrm{ha}^{-1}\right) \\
(\mathrm{n}=595 \text { transects })\end{array}$ & $\begin{array}{l}\text { Protected biomass } \\
\left(\mathrm{kg} \mathrm{ha}^{-1}\right)(\mathrm{n}=202 \\
\text { transects })\end{array}$ \\
\hline Mean & 230.63 & 335.79 \\
\hline Median & 134.51 & 213.98 \\
\hline $95^{\text {th }}$ Percentile & 730.75 & 1220.22 \\
\hline Std. Deviation & 401.50 & 404.54 \\
\hline
\end{tabular}

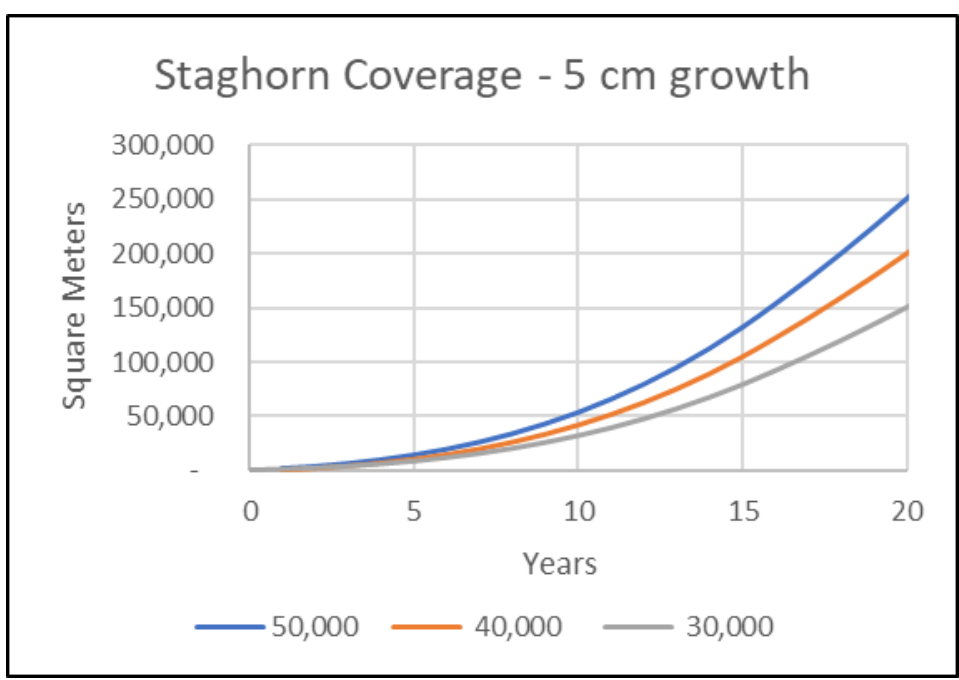

Figure 2. Staghorn coverage under alternative outplanting intensities

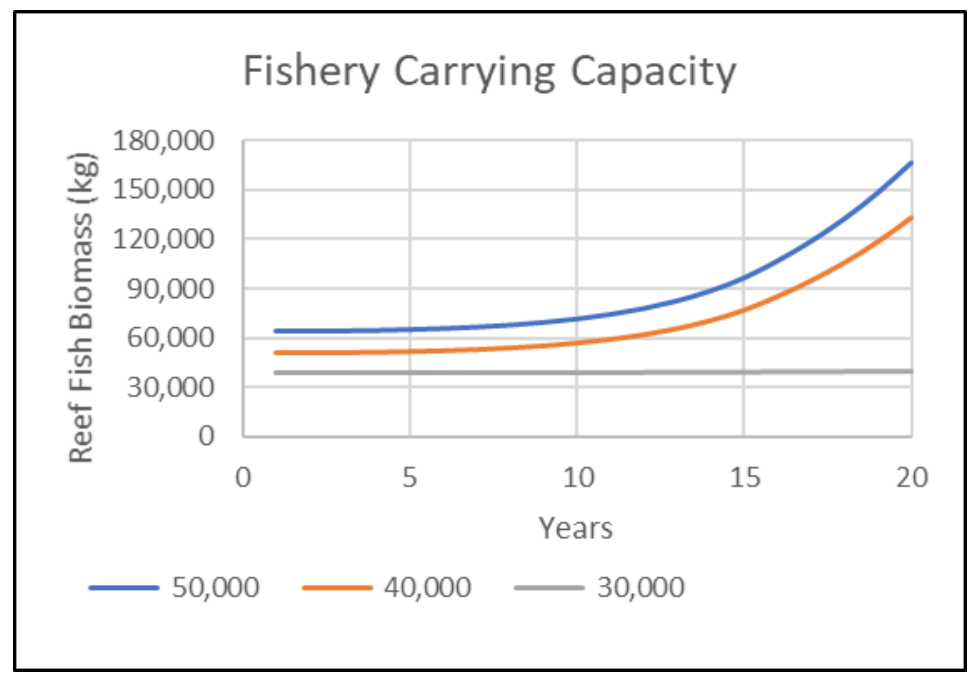

Figure 3. Fishery carrying capacity under alternative outplanting intensities 


\subsection{Optimally managed fishery}

With no reserve, baseline fish harvest in year 20 is $17.01 \mathrm{~kg} \mathrm{ha}^{-1} \mathrm{yr}^{-1}$, a $108.54 \%$ increase from $t=0\left(8.16 \mathrm{~kg} \mathrm{ha}^{-1} \mathrm{yr}^{-1}\right)$ as a result of increased coral abundance and fishery productivity from restocking. Total fish harvest over 20 years is $71,215 \mathrm{~kg}$ $\left(237.38 \mathrm{~kg} \mathrm{ha}^{-1}\right), 45.5 \%$ greater than with no restocking $\left(48,946 \mathrm{~kg} ; 163.15 \mathrm{~kg} \mathrm{ha}^{-1}\right)$. Fishery NPV is $\$ 262.21 \mathrm{ha}^{-1}, 13.05 \%$ greater than without restocking $\left(\$ 231.94 \mathrm{ha}^{-1}\right)$.

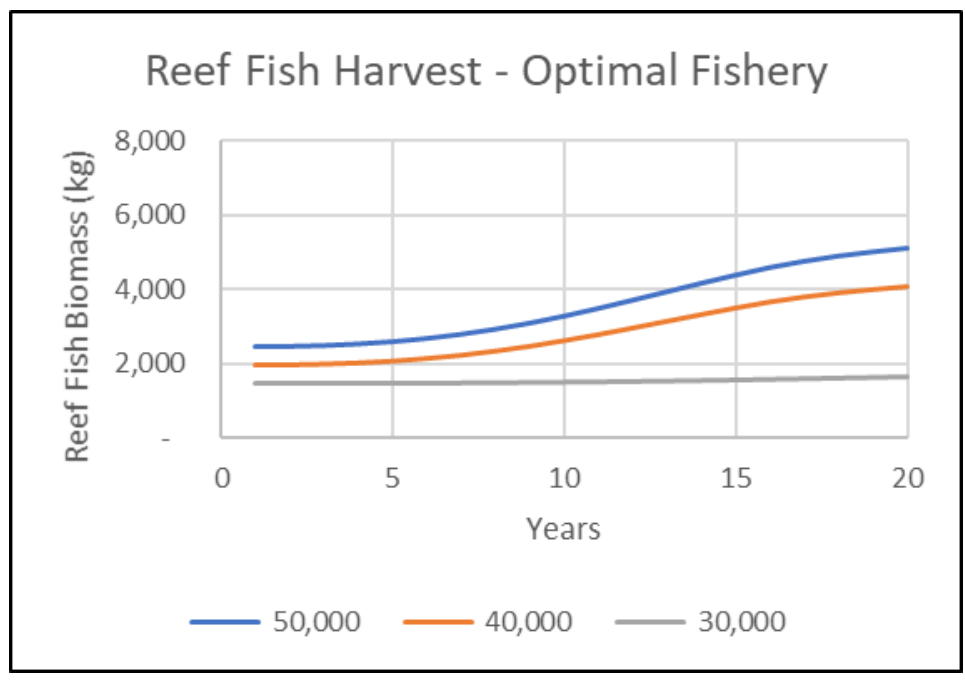

Figure 4. Fishery harvest under alternative outplanting intensities 


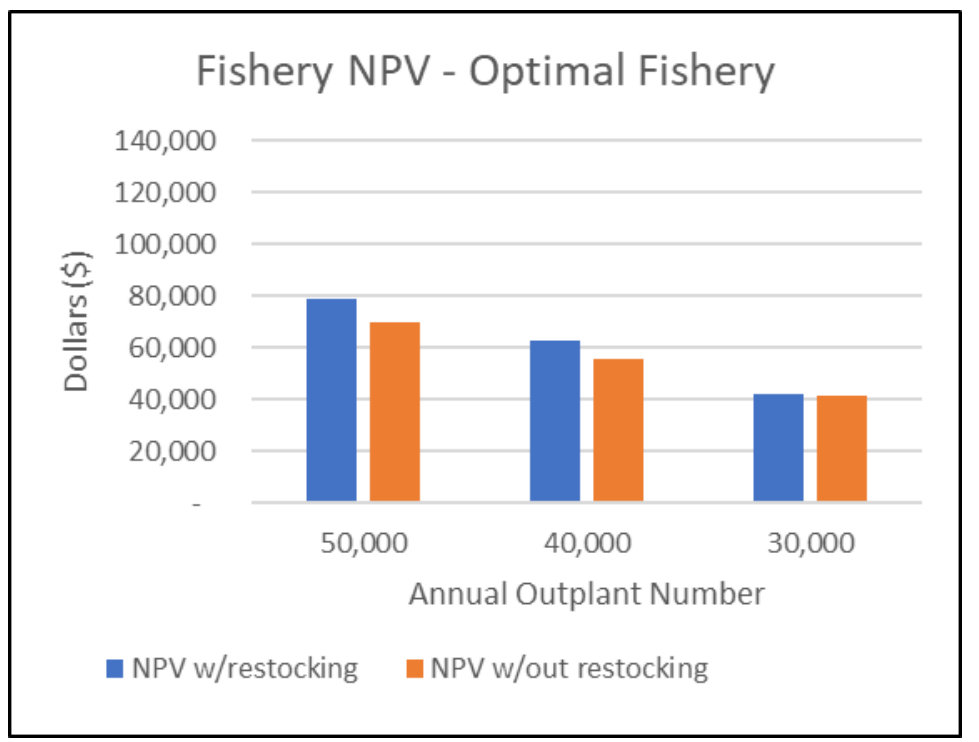

Figure 5. Fishery NPV - optimal fishery under alternative outplanting intensities 
Table 8. Model results $-5 \mathrm{~cm}$ annual major axis growth

\begin{tabular}{|c|c|c|c|c|c|}
\hline & \multicolumn{5}{|c|}{ Annual Outplant Volume } \\
\hline & $\begin{array}{c}\text { No } \\
\text { Restocking }\end{array}$ & $\begin{array}{c}50,000 \\
\text { (Baseline)* }\end{array}$ & $\begin{array}{c}50,000 \\
\text { Increased } \\
\text { mortality** }\end{array}$ & 40,000 & 30,000 \\
\hline $\begin{array}{l}\text { Year } 20 \text { carrying } \\
\text { capacity }\left(\mathrm{kg} \mathrm{ha}^{-1}\right)\end{array}$ & 213.98 & 553.58 & 504.13 & 553.58 & 221.80 \\
\hline Optimal Fishery & & & & & \\
\hline Harvest $\left(\mathrm{kg} \mathrm{ha}^{-1}\right)$ & 163.15 & 237.38 & 233.62 & 237.39 & 170.03 \\
\hline $\operatorname{NPV}\left(\$ \mathrm{ha}^{-1}\right)$ & 231.94 & 262.21 & 260.59 & 262.21 & 234.68 \\
\hline Reserve - ground & & & & & \\
\hline Harvest $\left(\mathrm{kg} \mathrm{ha}^{-1}\right)$ & 159.24 & 291.39 & 284.69 & 295.59 & 224.13 \\
\hline $\operatorname{NPV}\left(\$ \mathrm{ha}^{-1}\right)$ & 235.80 & 395.66 & 387.10 & 418.65 & 379.80 \\
\hline
\end{tabular}

*Baseline mortality: $15 \%$ \& 10\%, respectively, in years one and two. **15\% \& $10 \%$ outplant mortality in years one and two, $6 \%$ annual loss of staghorn area in years 3-20. Per ha values are for a 300-ha fishery.

\subsection{Marine reserve - grounds}

With the marine reserve, baseline harvest in year 20 is $23.72 \mathrm{~kg} \mathrm{ha}^{-1}$, a $197.92 \%$ increase from $t=0\left(7.96 \mathrm{~kg} \mathrm{ha}^{-1}\right)$ and $39.44 \%$ greater than with no reserve; Total harvest over 20 years is $87,417 \mathrm{~kg}\left(291.39 \mathrm{~kg} \mathrm{ha}^{-1}\right), 82.99 \%$ greater than with no restocking $\left(47,773 \mathrm{~kg} ; 159.24 \mathrm{~kg} \mathrm{ha}^{-1}\right)$, and $22.75 \%$ greater than with no reserve $(71,215$ $\left.\mathrm{kg} ; 237.38 \mathrm{~kg} \mathrm{ha}^{-1}\right)$. Fishery NPV is $\$ 395.66 \mathrm{ha}^{-1}$, an increase of $67.79 \%$ over $t=0$ $(\$ 235.80)$ and $33.73 \%$ greater than without the reserve $\left(\$ 262.21 \mathrm{ha}^{-1}\right)$.

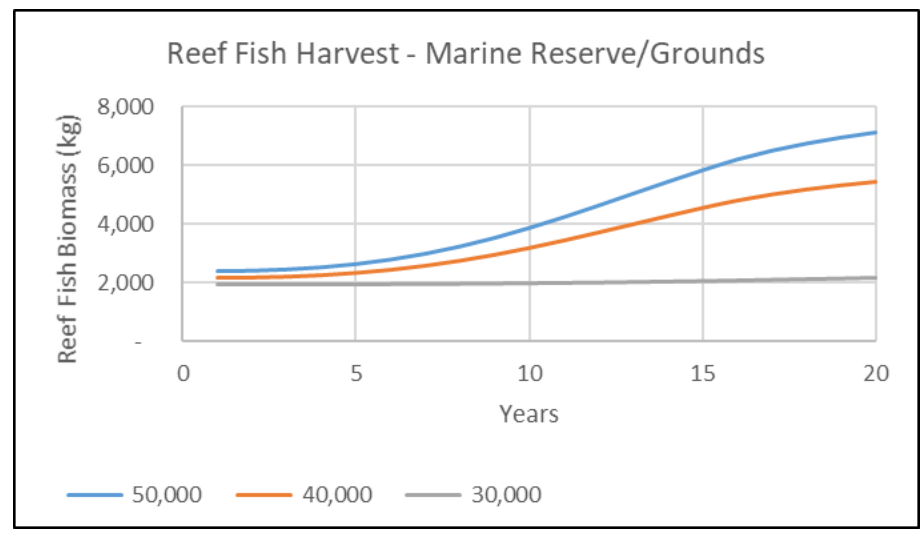

Figure 6. Fishery harvest under alternative outplanting intensities 


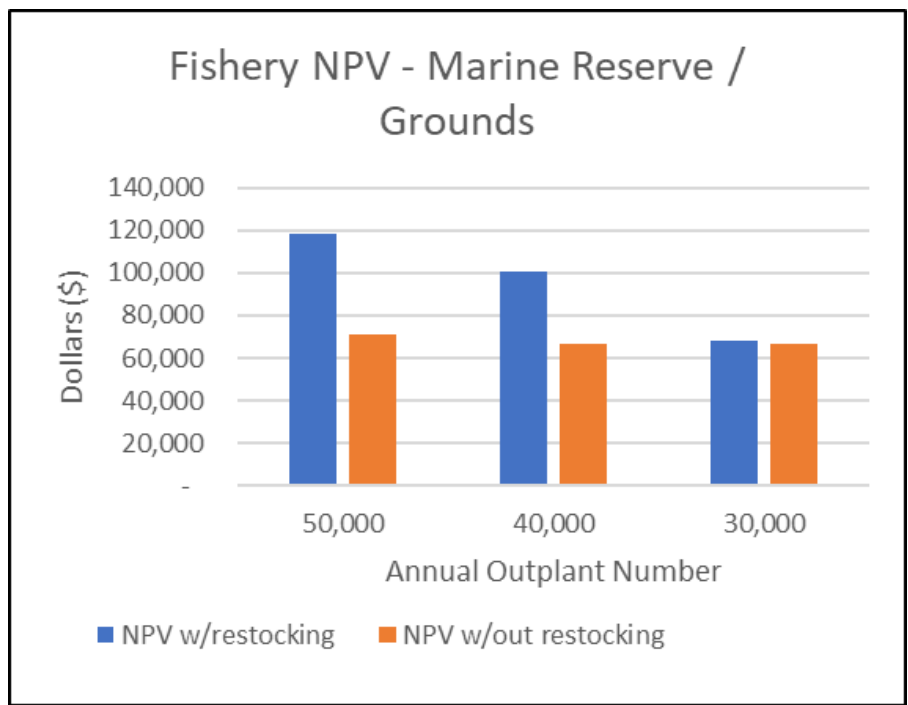

Figure 7. Fishery NPV with marine reserve under alternative outplanting intensities

4.0 Sensitivity analysis

4.1 Effect of outplant mortality rate

\subsubsection{Carrying capacity}

A decrease in the first- and second-year outplant mortality from baseline to $10 \%$ and 5\%, respectively, (a $40 \%$ relative drop), increases the year 20 carrying capacity $18.25 \%$ from $553.58 \mathrm{~kg} \mathrm{ha}^{-1}$ to $654.63 \mathrm{~kg} \mathrm{ha}^{-1}$ (from $166,074 \mathrm{~kg}$ to $196,388 \mathrm{~kg}$ ), relative to the baseline. An increase in first- and second-year mortality from the baseline to $20 \%$ and $15 \%$, respectively, (a 40\% relative increase) reduces year 20 carrying capacity by $21.66 \%$, from $553.58 \mathrm{~kg} \mathrm{ha}^{-1}$ to $455.01 \mathrm{~kg} \mathrm{ha}^{-1}(166,074 \mathrm{~kg}$ to $136,504 \mathrm{~kg})$. 
Table 9. Reserve-grounds model results with various mortality rates

\begin{tabular}{llll}
\hline $\begin{array}{l}\text { 1st, 2nd yr. } \\
\text { mortality }\end{array}$ & $\begin{array}{l}\text { Fishery } \\
\text { carrying } \\
\text { capacity } \\
(\mathrm{kg})\end{array}$ & $\begin{array}{l}\text { Total } \\
\text { harvest } \\
(\mathrm{kg})\end{array}$ & $\begin{array}{l}\text { Fishery } \\
\text { NPV }(\$)\end{array}$ \\
\hline $15 \% / 10 \%$ (Base) & 166,074 & 87,418 & 118,698 \\
$15 \% / 10 \% / 6 \% *$ & 151,237 & 70,086 & 78,176 \\
$20 \% / 15 \%$ & 136,504 & 83,062 & 113,162 \\
$10 \% / 5 \%$ & 196,388 & 91,249 & 123,650 \\
\hline
\end{tabular}

4.1.2 Fishery harvest and profit: marine reserve - grounds

A decrease of 5\% in the first- and second-year outplant mortality to $10 \%$ and $5 \%$, respectively, results in an increased fish harvest over 20 years of $4.38 \%$ or $3,831 \mathrm{~kg}$, over the baseline. The year 20 fish harvest is $2.75 \%$ greater $(7,312 \mathrm{~kg}$ vs. $7,116 \mathrm{~kg})$. Fishery profit increases $4.17 \%$ to $\$ 412.17 \mathrm{ha}^{-1}$ from $\$ 395.66 \mathrm{ha}^{-1}$. A $5 \%$ increase in first- and second-year outplant mortality from the baseline to $20 \%$ and $15 \%$, respectively, causes total fish harvest to decline $4.98 \%$, or 4,356 kg over 20 years. Year 20 fish harvest is $6,803 \mathrm{~kg}$ vs. the baseline fish harvest of $7,116 \mathrm{~kg}$, a difference of $4.40 \%$. Fishery profit decreases $4.67 \%$ to $\$ 377.21 \mathrm{ha}^{-1}$ from $\$ 395.66 \mathrm{ha}^{-1}$.

4.1.3 Fishery harvest and profit: optimally managed fishery

With no reserve, decreasing the first- and second-year outplant mortality to $10 \%$ and $5 \%$, respectively, increases fish harvest over 20 years $3.02 \%$ from $237.38 \mathrm{~kg} \mathrm{ha}^{-1}$ to $244.56 \mathrm{~kg} \mathrm{ha}^{-1}(71,215 \mathrm{~kg}$ to $73,367 \mathrm{~kg})$. Year 20 fish harvest with decreased outplant mortality is 5,213 vs. 5,103 , an increase of $2.16 \%$. With increased outplant mortality, total fish harvest is $229.23 \mathrm{~kg} \mathrm{ha}^{-1}$ vs. $237.38 \mathrm{~kg} \mathrm{ha}^{-1}$, a decline of $3.43 \%(68,768 \mathrm{~kg} \mathrm{vs}$. 
$71,215 \mathrm{~kg}$ ). Year 20 fish harvest is 4,926 vs. 5,213, a decline of 5.51\%. With decreased mortality, fishery profit increases $1.19 \%$ to $\$ 265.33 \mathrm{ha}^{-1}$ from $\$ 262.21 \mathrm{ha}^{-1}$. Increasing the outplant mortality reduces fishery profit by $1.33 \%$ to $\$ 229.23 \mathrm{ha}^{-1}$. As with the reserve, marginal impacts of outplant mortality are greater when mortality decreases (vs. increases) from the baseline although less in the optimal fishery.

\subsection{Effect of outplant volume}

\subsubsection{Carrying capacity}

Decreasing outplant volume results in decreased total fishery carrying capacity, fish harvest, and profit, although per unit area results are mixed. Planting 40,000 colonies, fishery carrying capacity in year 20 is the same as the baseline at $553.58 \mathrm{~kg}$ ha

${ }^{1}$, while total carrying capacity falls to $132,859 \mathrm{~kg}$ from $166,074 \mathrm{~kg}$. Planting 30,000 outplants, fishery carrying capacity falls $75.96 \%$ from the baseline to $221.80 \mathrm{~kg} \mathrm{ha}^{-1}$ $(39,924 \mathrm{~kg})$.

4.2.2 Fishery harvest and profit: marine reserve - grounds

Decreasing outplant volume to 40,000 from the baseline (a 20\% decrease), total harvest falls $18.85 \%$ from 87,418 to 70,942 , however, per-unit-area harvest increases $1.42 \%$ from $291.39 \mathrm{~kg} \mathrm{ha}^{-1}$ to $295.59 \mathrm{~kg} \mathrm{ha}^{-1}$. With 30,000 colonies, total harvest falls $53.85 \%$ to 40,343 ; year 20 harvest declines $23.08 \%$ from the baseline to $224.13 \mathrm{~kg} \mathrm{ha}^{-1}$. When outplant volume is reduced from 50,000 to 40,000, total fishery NPV falls $15.35 \%$ from $\$ 118,698$ to $\$ 100,477$, however, per ha NPV increases 5.8\% to $\$ 418.65 \mathrm{ha}^{-1}$ from $\$ 395.66 \mathrm{ha}^{-1}$. Per ha NPV drops to $\$ 379.80 \mathrm{ha}^{-1}$ with 30,000 outplants, a decrease of 
$4.01 \%$ from the baseline; Total NPV falls $42.41 \%$ from the baseline to $\$ 68,364$. The increase in unit-area-value and fish harvest from reducing outplant volume to 40,000 from the baseline is counterintuitive and, at least, partially due the higher marginal cost of harvest associated with the larger fishery. Costs increase $25 \%$ with the larger fishery (300 ha vs. 240 ha) while harvest increases $23 \%$.

Table 10. Results with various growth rates and outplanting intensities

\begin{tabular}{cccccc}
\hline \multicolumn{5}{c}{ Marine Reserve - Grounds } \\
\hline $\begin{array}{c}\text { Annual } \\
\text { growth } \\
(\mathrm{cm})\end{array}$ & $\begin{array}{c}\text { Annual } \\
\text { outplants }\end{array}$ & $\begin{array}{c}\text { Harvest } \\
(\mathrm{kg})\end{array}$ & $\begin{array}{c}\text { NPV } \\
(\$)\end{array}$ & $\begin{array}{c}\text { Harvest } \\
\text { before } \\
\text { restocking } \\
(\mathrm{kg})\end{array}$ & $\begin{array}{c}\text { NPV before } \\
\text { restocking } \\
(\$)\end{array}$ \\
\hline 5 & 50,000 & 87,418 & 118,698 & 47,773 & 70,739 \\
5 & 40,000 & 70,942 & 100,477 & 43,620 & 66,459 \\
5 & 30,000 & 40,343 & 68,364 & 39,120 & 66,712 \\
\hline 4 & 50,000 & 78,972 & 108,132 & 47,773 & 70,739 \\
4 & 40,000 & 65,121 & 92,982 & 43,620 & 66,459 \\
4 & 30,000 & 40,024 & 67,929 & 39,120 & 66,712 \\
\hline 3 & 50,000 & 69,628 & 96,778 & 47,773 & 70,739 \\
3 & 40,000 & 58,680 & 84,929 & 43,620 & 66,459 \\
3 & 30,000 & 39,725 & 67,523 & 39,120 & 66,712 \\
\hline
\end{tabular}

4.2.3 Fishery harvest and profit: optimally managed fishery

Decreasing staghorn outplant volume to 40,000 from the baseline, unit area harvest remains the same as the baseline at $237.38 \mathrm{~kg} \mathrm{ha}^{-1}$. Fish harvest falls to $170.02 \mathrm{~kg}$ ha $^{-1}$ planting 30,000 colonies annually, a decline of 57.02\% from the baseline. Fishery NPV remains $\$ 262.21 \mathrm{ha}^{-1}$ when outplant volume is reduced from 50,000 to 40,000, however, NPV drops to $\$ 234.68 \mathrm{ha}^{-1}$ with 30,000 outplants, a decrease of $10.50 \%$. 
Table 11. Results with various growth rates and outplanting intensities

\begin{tabular}{cccccc}
\hline \multicolumn{6}{c}{ Optimal Fishery } \\
\hline $\begin{array}{c}\text { Annual } \\
\text { growth } \\
(\mathrm{cm})\end{array}$ & $\begin{array}{c}\text { Annual } \\
\text { outplants }\end{array}$ & $\begin{array}{c}\text { Harvest } \\
(\mathrm{kg})\end{array}$ & $\begin{array}{c}\text { NPV } \\
(\$)\end{array}$ & $\begin{array}{c}\text { Harvest } \\
\text { before } \\
\text { restocking } \\
(\mathrm{kg})\end{array}$ & $\begin{array}{c}\text { NPV } \\
\text { before } \\
\text { restocking } \\
(\$)\end{array}$ \\
\hline 5 & 50,000 & 71,215 & 78,663 & 48,946 & 69,583 \\
5 & 40,000 & 56,973 & 62,931 & 39,156 & 61,666 \\
5 & 30,000 & 30,605 & 42,243 & 29,369 & 41,751 \\
\hline 4 & 50,000 & 66,471 & 76,662 & 48,946 & 69,583 \\
4 & 40,000 & 53,177 & 61,331 & 39,156 & 61,666 \\
4 & 30,000 & 30,280 & 42,113 & 29,369 & 41,751 \\
\hline 3 & 50,000 & 61,222 & 74,512 & 48,946 & 69,583 \\
3 & 40,000 & 48,978 & 59,611 & 39,156 & 61,666 \\
3 & 30,000 & 29,975 & 41,992 & 29,369 & 41,751 \\
\hline
\end{tabular}

\subsection{Discussion}

Using comparative statics, this study attempts to fill gaps in our understanding of how restocking and protecting staghorn populations on the FRT impacts the delivery and value of reef ecosystem services, namely support of commercial reef fish fisheries. We found that large-scale restocking and protection of staghorn populations may be effective in increasing commercially important reef fish carrying capacity, and optimal stocks, harvest, and fishery value. This result is consistent with literature examining the relationship between reef complexity and reef fish abundance and diversity (e.g., Clark and Edwards, 1998; Walker, et al., 2009; Rogers et al., 2014). In the optimally managed fishery, depending on treatment size, restocking increases fishery harvest and profit by as much as $45.50 \%$ and $13.05 \%$, respectively. With the marine reserve protecting outplanted colonies, restocking increases fishery harvest and profit by as much as $85.63 \%$ and $77.50 \%$, respectively, despite a $33.33 \%$ reduction in the size of the fishing grounds. The direction of these results, not necessarily the magnitude, are consistent with previous 
studies examining fisheries benefit of marine reserves (Roberts, et al., 2001; Micheli, et al., 2004; Jeffrey, et al., 2012).

Because we introduce the fisheries benefit of the marine reserve only through the intrinsic growth rate of the stock (and not carrying capacity) in our model, management regime has no impact on fishery carrying capacity; if coral coverage is enhanced by protection, our model may underestimate the fisheries benefits. Cases of marine reserves supporting coral cover and resilience have been documented (i.e., Mumby and Harborne, 2010), however, results from studies are mixed. Examining three no-take reserves and three sites open to fishing in the Florida Keys, Toth, et al., (2014) found that 14 years of protection did not influence coral cover. Huntington, Karnauskas, and Lirman (2011) found, after 10 years of protection, no clear indication of benefits to coral cover, colony size, or number of juvenile corals on Glovers Reef, Belize. Examining 10 sites in and outside of marine reserves in the Bahamas, Mumby and Harborne (2010) found rates of coral cover significantly higher in marine reserves than outside. Other studies have found declines in stony coral cover may continue for years after initial protection (Selig and Bruno, 2010). Many of the causes of staghorn declines on the FRT originate beyond the boundaries of marine reserves and jurisdiction of local resource managers. Water quality in the Florida Keys is impacted by inputs from the Everglades, Florida Bay, and the southwest Florida coast and rising ocean temperatures and acidification associated with global climate change are primary drivers of coral bleaching.

In the optimal fishery, per ha harvest and NPV from outplanting 40,000 colonies are the same for treatments of 50,000 colonies and dramatically higher than with 30,000. With the marine reserve, values decline slightly from 40,000 to 50,000 outplants. On the 
basis of per hectare harvest and profit values, treatments of 40,000 colonies ( 4 ha) are the most economically efficient of the three sizes examined. The marginal fishery benefits from protection are greatest with treatments of 30,000 colonies. At this level of outplanting, harvest and profit are $31 \%$ and $61 \%$ higher than without the marine reserve suggesting protection can be a vital component in the success of small restocking projects, in terms of fisheries benefits.

Our per hectare fishery values of $\$ 234.68$ to $\$ 418.65$, derived as the discounted value of the stream of revenues over the 20 year outplanting period, are consistent with previous studies finding annual US coral reef commercial fishery values ranging from \$36 to \$605 (2007 prices) (Brander and van Beukering, 2013). MacNeil et al. (2006) estimated, in the absence of fishing, global mean resident reef fish biomass should be $1,013 \mathrm{~kg} \mathrm{ha}^{-1}(963,1469)$; on heavily fished reefs, biomass was found to be $158 \mathrm{~kg} \mathrm{ha}^{-1}$. Derived from local abundance data, our optimal stock estimates range from $144 \mathrm{~kg} \mathrm{ha}^{-1}$ to $153 \mathrm{~kg} \mathrm{ha}^{-1}$ and baseline carrying capacities range from $572 \mathrm{~kg} \mathrm{ha}^{-1}$ to $597.54 \mathrm{~kg} \mathrm{ha}^{-1}$. Our results appear low relative to McNeil and may reflect the relatively depleted state of the Keys commercial reef fish fishery.

Our model does not account for the contribution of outplant reproduction (sexual or asexual) to staghorn coverage. Staghorn coral has a propensity to reproduce asexually through fragmentation and colonies in the FKNMS have been observed spawning two years after outplanting. Reproductive output of staghorn corals is largely influenced by colony fecundity and population size and density (Knowlton, 2001) so marine reserves that support growth or survivorship of outplants may have substantial cumulative effects over the long term, which for model simplicity is not captured in our simulation, 
particularly considering the enhanced reproductive capacity of populations connected by restocking.

Colony mortality occurs only in years one and two in our model, $15 \%$ and $10 \%$, respectively, in the baseline scenario (75\% survivorship). Examining regional staghorn restoration programs, Schopmeyer, et al. (2017) found staghorn outplant survival to be 85.2+- $9.7 \% 12$ months after transplanting ( $n=933$ colonies); three programs that tracked mortality beyond the first year found two year outplant survivorship to be $75 \%$ (Schopmeyer, 2017). The marginal impact of mortality on carrying capacity, harvest, and NPV is greater when mortality increases from the baseline vs. when mortality decreases, suggesting marginal impacts to fisheries from changes in staghorn abundance are greater at lower levels of staghorn abundance.

We simulate outplant growth rates of three, four, and five $\mathrm{cm} \mathrm{yr}^{-1}$. Typical staghorn growth rates range from $3.5-11 \mathrm{~cm} / \mathrm{yr}$. (Gladfelter, 1984) and more than $20 \mathrm{~cm}$ $\mathrm{yr}^{-1}$ has been observed (Tunnicliffe, 1983). A difference of $1 \mathrm{~cm}$ in annual colony growth rate may affect harvest over 20 years by over $10 \%$, reinforcing the premise that the success and efficiency of restocking will be influenced by efforts to addresses local and global stressors affecting staghorn growth, health and resilience. With 30,000 outplants, harvest and NPV exhibit increasing returns as annual colony growth rate increases (i.e., the incremental increase in harvest and NPV grows as annual growth increases) whereas with 40,000 and 50,000 annual outplants, harvest and NPV exhibit diminishing returns to scale. This response is similar under both management regimes, although smaller with the optimal fishery, and again suggests impacts to fisheries from changes in staghorn coverage are greater at lower levels of staghorn abundance. 
Limited knowledge of the linkages between staghorn coral and commercial reef fish stocks is a major obstacle to economic valuation of reef restoration efforts, particularly given the uncertainty surrounding the long term recovery path of outplanted staghorn colonies. Unlike in our simplified model, outplant growth and aggregate staghorn area resulting from restockng are likley to be non-linear and heterogenous across space and time as corals experience periods of growth and dieoff (Goergen et al., 2019).

A comprehensive restocking program is underway to support remaining natural staghorn coral populations in SE Florida. Our results suggests large scale restocking and protection of staghorn corals can be effective in enhancing local fishery productivity and value. Although staghorn corals support other species on the FRT, we examine commercial reef fish because they are most commerically valuable and data existed to support our analysis. Therefore, the total benefit of outplant staghorn estimated in our study should be viewed as only a conservative, lower bound estimate.

Our study represents a first attempt to approximate the ecological and economic contribution to commercial reef fish fisheries from restocking staghorn coral populations on the FRT and contributes to the existing literature by establishing a general framework to examine the fishery impacts from restocking that may be applied to projects elsewhere. Results can inform decision making related to the management of Florida's coastal resources, including the scale and intensity of restocking efforts and use of marine reserves to maximize returns. Quantifying the potential value of improved management can also support justification for scarce conservation funding. Ultimately, decisions related to large-scale restocking, particularly if coupled with marine reserves, will be 
made upon examination of many complex ecological and socio-economic issues likely to affect local, regional, and national stakeholders that rely on the coral reef ecosystems of the Florida Keys for their livelihood, recreation, and overall well-being.

\section{References}

Acropora Biological Review Team. 2005. Atlantic Acropora Status Review Document. National Marine Fisheries Service Report. 152 p.

Adey, W. H., Burke, R. B., 1977. Holocene Bioherms of Lesser Antilles - Geologic Control of Development. In: Frost, S. H., Weiss, M. P., Saunders, J. B. (eds.) Reefs and Related Carbonates. American Association. Petroleum Geologists. Tulsa, Oklahoma, pp. 67-81.

Ahmed, M., Chong, C.K.., Cesar, H., (Eds.) 2003. Economic Valuation and Policy Priorities for the Sustainable Management of Coral Reefs.

Allgeier, J., Valdavia, A., Cox, C., Layman, C., 2015. Fishing Down Nutrients on Coral Reefs. Nature Communications. DOI: 10.1038/ncomms12461.

Aronson, R.B., Precht, W.F., 2001. White-band Disease and the Changing Face of Caribbean Coral Reefs. Hydrobiologia. 460:1, 25-38.

Aronson, R.B., Precht, W.F., 2006. Conservation, Precaution, and Caribbean reefs. Coral Reefs. 25, 441. doi:10.1007/s00338-006-0122-9.

Ault, J.S., Bohnsack, J.A., Meester, G., 1998. A retrospective (1979-1995) multispecies assessment of coral reef fish stocks in the Florida Keys. Fish. Bull. 96(3): 395-414.

Ault, J.S., Smith, S.G., Meester, G.A., Luo, J., Bohnsack, J.A., 2001. Site Characterization for Biscayne National Park: Assessment of Fisheries Resources and Habitats. NOAA Technical Memorandum NMFS SEFSC 468. Miami, FL. 185 pp.

Ault, J.S., Smith, S.G., Bohnsack, J.A., 2005. Evaluation of Average Length as an Indicator of Exploitation Status for the Florida Coral-Reef Fish Community. ICES J. Mar. Sci. 62, 417-423.

Ault, J.S., Bohnsack, J.A., Smith, S.G., Luo, J., 2005. Towards Sustainable Multispecies Fisheries in the Florida, USA, Coral Reef Ecosystem. Bull. Mar. Sci. 76:2, 595-622. 
Ault, J.S., Smith, S.G., Bohnsack, J.A., Luo, J., Harper, D.E., McClellan, D.B., 2006. Building Sustainable Fisheries in Florida's Coral Reef Ecosystem: Positive Signs in the Dry Tortugas. Bull. Mar. Sci. 78:3, 633-654.

Ault., J.S., Smith, S.G., Bohnsack, J.A., Luo, J., Zurcher, N., McClellan, D.B., Ziegler, T.A., Hallac, D., 2013. Assessing Coral Reef Fish Population and Community Changes in Response to Marine Reserves in the Dry Tortugas, Florida, USA. Fisheries Research. 144:28-37.

Barbier, E.B., 2000. Valuing the Environment as Input: Review of Applications to Mangrove-Fishery Linkages. Ecological Economics. 35:1, 47-61.

Barbier, E.B., Strand, I., 1998. Valuing Mangrove-Fishery Linkages: A Case Study of Campeche, Mexico. Environmental and Resource Economist. 12, 151-166.

Bateman, I.J., Brainard, J.S., Lovett, A.A., 1995. Modelling Woodland Recreation Demand Using Geographical Information Systems: A Benefits Transfer Study. Global Environmental Change Working Paper 95-06, Centre for Social and Economic Research on the Global Environment (CSERGE), University College London and University of East Anglia, Norwich.

Bell, F.W., 1989. Application of Wetland Valuation Theory to Florida Fisheries. Report No. 95, Florida Sea Grant Program, Florida State University, Tallahassee.

Bell, F.W., 1997. The Economic Value of Saltwater Marsh Supporting Marine Recreational Fishing in the Southeastern United States. Ecol. Econ. 21, 243-254.

Bhat, M., 2002. Application of Non-Market Valuation to the Florida Keys Marine Reserve Management. Journal of Environmental Management. 67, 315-325.

Bhat, M.G., Bhatta, R., 2006. Mechanization and Technical Interactions in Multi-Species Indian Fisheries: Implications for Economic and Biological Sustainability. Marine Policy. $30,237-248$.

Birkeland, C., 1997. Life and Death of Coral reefs. Chapman and Hall, New York, p. 536.

Bishop, R., Chapman, D., Kanninen, B., Krosnick, J., Leeworthy, B., Meade, N., 2011. Total Economic Value for Protecting and Restoring Hawaiian Coral Reef Ecosystems: Final Report. Silver Spring, MD: NOAA: Office of National Marine Sanctuaries, Office of Response and Restoration, and Coral Reef Conservation Program. NOAA Technical Memorandum CRCP 16. 406pp.

Bohnsack, J. A., Harper, D. E., 1988. Length-Weight Relationships of Selected Marine Reef Fishes from the Southeastern United States and the Caribbean. NOAA Technical Memorandum NMFS-SEFC. 215, 31p. 
Bohnsack, J. A., 1990. The Potential of Marine Fishery Reserves for Reef Fish Management in the US Southern Atlantic. NOAA Tech. Mem. NMFS-SEFC. 261, 1-40.

Bowden-Kerby, A., 2001. Low-tech Coral Reef Restoration Methods Modeled After Natural Fragmentation Processes. Bulletin of Marine Science. 69, 915-931.

Brander, L., van Beukering, P., 2013. The Total Economic Value of U.S. Coral Reefs: A Review of the Literature. NOAA Coral Reef Conservation Program, Silver Spring, MD.

Brandt, M.E., Zurcher, Acosta, A., Ault, J.S., Bohnsack, J.A., Feeley, M.W., Harper, D.E., Hunt, J.H., Kellison, T., McClellan, D.B., Patterson, M.E., Smith, S.G., 2009. A Cooperative Multi-Agency Reef Fish Monitoring Protocol for the Florida Keys Coral Reef Ecosystem. Natural Resource Report NPS/SFCN/NRR-2009/150. National Park Service, Fort Collins, Colorado.

Bruckner, A.W., 2002. Proceedings of the Caribbean Acropora Workshop: Potential Application of the US Endangered Species Act as a Conservation Strategy. NOAA Tech Memo NMFSOPR-24, Silver Spring, MD. 199 p.

Burke, L., Maidens, J., 2004. Reefs at Risk in the Caribbean. Washington, DC.: World Resources Institute. Available from: http://pdf.wri.org/reefs_caribbean_full.pdf. Accessed April 2016.

Burke L.M., Reytar, K., Spalding, M., Perry, A., 2011. Reefs at Risk Revisited. World Resources Institute, Washington, DC. p.114.

Carte', B.K., 1996. Biomedical Potential of Marine Natural Products. Bioscience 46:4, 271-286.

Clark, C.W., 1990. Mathematical Bioeconomics - The Optimal Management of Renewable Resources, second ed. Wiley InterScience, New York.

Claudet, J. D., Pelletier, J.Y., Jouvenel, Y., Bachet, F., Galzin, R. 2006. Assessing the Effects of Marine Protected Area (MPA) on a Reef Fish Assemblage in a Northwestern Mediterranean Marine Reserve: Identifying Community-Based Indicators. Biological Conservation. 130, 349-369.

Conrad, J., 1999. The Bioeconomics of Marine Sanctuaries. Journal of Bioeconomics. 1, 205- 217.

Cook, G.S., Heinen, J.T. 2005. On the uncertain costs and tenuous benefits of marine reserves: A case study of the Tortugas Ecological Reserve, South Florida, USA. Natural Areas Journal. 25:4. 
Cooper, T.F., Gilmour, J.P., Fabricius, K.E., 2009. Bioindicators of Changes in Water Quality on Coral Reefs: Review and Recommendations for Monitoring Programmes. Coral Reefs. 28:3, 589-606.

Copper, P., 1994. Ancient Reef Ecosystem Expansion and Collapse. Coral Reefs. 13, 311.

Craik, W., Kenchington, R., Kelleher, G., 1990. Coral-Reef Management. In: Dubinsky, Z. (Ed.), Ecosystems of the World 25: Coral Reefs. Elsevier, New York, pp. 453-467.

Darling, E.S., Graham, N.A.J., Januchowski-Hartley, F.A., Nash, K.L., Pratchett, M.S., Wilson, S.K., 2017. Relationships Between Structural Complexity, Coral Traits, and Reef Fish Assemblages. Coral Reefs. 36: 561-575.

Davis, G.E., 1982. A Century of Natural Change in Coral Distribution at the Dry Tortugas: a Comparison of Reef Maps from 1881-1976. Bull Mar Sci. 32, 608-623.

Done, T. J. 1999. Coral Community Adaptability to Environmental Change at the Scales of Regions, Reefs, and Reef Zones. American Zoologist. 39,66-79

Done, T.J., Ogden, J.C., Wiebe, W.J., Rosen, B.R., 1996. Biodiversity and Ecosystem Function of Coral Reefs. In: Mooney, H.A., Cushman, J.H., Medina, E., Sala, O.E., Schulze, E.D. (Eds.), Functional Roles of Biodiversity: A Global Perspective. SCOPE 1996, John Wiley and Sons.

Ellis, G.M., Fisher. A.C., 1987. Valuing the environment as input. Journal of Environmental Management 25:149-156.

Epstein, N., Bak, R.P.M, Rinkevich, B., 2001. Strategies for Gardening Denuded Coral Reef Areas: The Applicability of Using Different Types of Coral Material for Reef Restoration. Restoration Ecology. 9,432-442. http://dx.doi.org/10.1046/j.1526100X.2001.94012.X

Epstein, N., Bak, R.P.M., Rinkevich, B., 2003. Applying Forest Restoration Principles to Coral Reef Rehabilitation. Aquatic Conservation. 13, 387-395. http://dx.doi.org/10.1002/aqc.558

Farrow, S., Toman, M., 1999. Using Benefit-Cost Analysis to Improve Environmental Regulations. Environment. 41:2.

Foley, N.S., Armstrong, C.W., Kahui, V., Mikkelsen, E., Reithe, Siv., 2012. A review of bioeconomic modeling of habitat-fishery interactions. International Journal of Ecology. $11 \mathrm{pp}$.

Froese, R., Pauly, D., Editors. 2018. FishBase. World Wide Web electronic publication. www.fishbase.org, version (02/2018). 
Gaines, S.D., White, C., Carr, M. H., Palumbi, S. R., 2010. Designing Marine Reserve Networks for both Conservation and Fisheries Management. Proceedings of the National Academy of Sciences of the United States of America. 107, 18286-18293.

Garcia-Charton, J.A., Perez-Ruzafa, A., Marcos, C., 2008. Effectiveness of European Atlanto-Mediterranean MPAs: Do They Accomplish the Expected Effects on Populations, Communities and Ecosystems? Journal for Nature Conservation. 16, 193221.

Geister, J., 1977 The Influence of Wave Exposure on the Ecological Zonation of Caribbean Coral Reefs. Proceedings of the 3rd International Coral Reef Symposium. 1, 23-29.

Goergen, E.A., Moulding, A.L., Walker, B.K., Gilliam, D.S. 2019. Identifying Causes of Temporal Changes in Acropora cervicornis Populations and the Potential for Recovery. Frontiers in Marine Science. 6:36.

Gladfelter, E.H., 1983. Skeletal Development in Acropora Cervicornis II: Diel Patterns of Calcium Carbonate Accretion. Coral Reefs 2: 91-100.

Goldberg, W.M., 1973. The Ecology of the Coral-Octocoral Communities off the Southeast Florida Coast: Geomorphology, Species Composition, and Zonation. Bull Mar Sci. 23, 465-488

Goreau, T.F., 1959. The Physiology of Skeleton Formation in Corals I. A Method for Measuring the Rate of Calcium Deposition by Corals under Different Conditions. The Biological Bulletin.

116, 59-75.

Goreau, T., Hilbertz, W., 2005. Marine Ecosystem Restoration: Costs and Benefits for Coral Reefs. World Journal of Research and Review. 17:3, 375-409.

Goreau, T.J., Hilbertz, W., Hakeem, A.A.A., Sarkisian, T., Gutzeit, F., Spenhoff, A., 2012. Restoring Reefs to Grow Back Beaches and Protect Coasts from Erosion and Global sea level rise. In: Innovative Methods of Marine Ecosystem Restoration. Goreau, T.J., Trench, R.K. (Ed.). CRC Press. 11-34.

Graham, N.A.J., Wilson, S.K., Jennings, S., Polunin, N.V.C., Bijoux, J.P., Robinson, J., 2006. Dynamic Fragility of Oceanic Coral Reef Ecosystems. Proc. Natl Acad. Sci.

U.S.A., 103, 8425-8429.

Graham., N.A.J., Nash, L., 2013. The Importance of Structural Complexity in Coral Reef Ecosystems. Coral Reefs. 32:2, 315-326. 
Guannel G., Arkema, K., Ruggiero, P., Verutes, G., 2016. The Power of Three: Coral Reefs, Seagrasses, and Mangroves Protect Coastal Regions and Increase Their Resilience. PLoS ONE 11:7.

Halpern, B.S., 2003. The Impact of Marine Reserves: Do Reserves Work and Does Reserve Size Matter? Ecological Applications. 13, S117-S137.

Hanley, N., Barbier, E.B., 2009. Pricing nature. Cost-benefit analysis and environmental policy. Edward Elgar, Cheltenham, UK, 2009.

Hastings, A., Botsford, L. W., 1999. Equivalence in Yield from Marine Reserves and Traditional Fisheries Management. Science 284, 1537-1538.

Heal, G.M., Barbier, E.B., Boyle, K.J., Covich, A.P., Gloss, S.P., Hershner, C.H., Hoehn, J.P., Pringle, C.M., Polasky, S., Segerson, K., Shrader-Frechette, K. 2005. Valuing Ecosystem Services: Toward Better Environmental Decision Making. Washington, DC: National Academies Press.

Highsmith, R.C., 1982. Reproduction by Fragmentation in Corals. Marine Ecology Progress Series 7, 207-226. http://dx.doi.org/10.3354/meps007207.

Hughes, T. P., 1984. Population Dynamics Based on Individual Size Rather than Age: A General Model with a Reef Coral Example. The American Naturalist. 123,778-795.

Hughes, T. P., Baird, A. H., Bellwood, D. R., Card, M., Connolly, S. R., Folke, C., Grosberg, R., Hoegh-Guldberg, O., Jackson, J. B. C., Kleypas, J., Lough, J. M., Marshall, P., Nyström, M., Palumbi, S. R., Pandolfi, J. M., Rosen, J. M., Roughgarden, J. M. J., 2003. Climate Change, Human Impacts, and the Resilience of Coral Reefs. Science. 301:5635, pp.929-933. DOI: 10.1126/science.1085046.

Hundloe, T.J., 1990. Measuring the Value of the Great Barrier Reef. Australian Parks and Recreation. 26,11-15

Huntington, B. E., Karnauskas, M., Lirman, D., 2011. Corals Fail to Recover at a Caribbean Marine Reserve Despite Ten Years of Reserve Designation. Coral Reefs. 30:4, 1077-1085. https://doi.org/10.1007/s00338-011-0809-4.

Huntington, B.E., Miller, M.W., 2013. Location-Specific Metrics for Rapidly Estimating the Abundance and Condition of the Threatened Coral Acropora Cervicornis. Restoration Ecology. doi:10.1111/rec.12057

Jaap, W.C., 1984. The Ecology of South Florida Coral Reefs: A Community Profile. U.S. Fish and Wildlife Service. FWS/OBS-82/08. 138pp.

Jackson, J.B.C., 1992, Pleistocene perspectives on coral reef community structure: American Zoologist, v. 32, p. 719-731. 
Jackson, J.B.C., Kirby, M.X., Berger, W.H., Bjorndal, K.A., Botsford, L.W., Bourque, B.J., Bradbury, R.H., Cooke, R., Erlandson, J., Estes, J.A., Hughes, T.P., Kidwell, S., Lange, C.B., Lenihan, H.S., Pandolfi, J.M., Peterson, C.H., Steneck, R.S., Tegner, M.J. and Warner, R.R., 2001. Historical Overfishing and the Recent Collapse of Coastal Ecosystems. Science, New Series 293:5530, pp. 629-638.

http://www.jstor.org/stable/3084305.

Jeffrey, C.F.G., Leeworthy, V.R., Monaco, M.E., Piniak, G., Fonseca, M. (eds.). 2012. An Integrated Biogeographic Assessment of Reef Fish Populations and Fisheries in Dry Tortugas: Effects of No-take Reserves. NOAA Technical Memorandum NOS NCCOS 111. Prepared by the NCCOS Center for Coastal Monitoring and Assessment Biogeography Branch. Silver Spring, MD. 147 pp.

Johns, G.M., Leeworthy, V.R., Bell, F.W., Bonn, M.A. 2003. Socioeconomic Study of Reefs in Southeast Florida, Final Report October 2001 and revised June 2003. Report for Broward, Palm Beach, Miami Dade and Monroe Counties, Florida Fish and Wildlife Conservation Commission, National Oceanic and Atmospheric Administration. http://marineeconomics.noaa.gov/Reefs/02-01.pdf.

Johnson, M.E., Lustic, C., Bartels, E., Baums, I.B., Gilliam, D.S., Larson, E.A., Lirman, D., Miller, M.W., Nedimyer, K., Schopmeyer, S., 2011. Caribbean Acropora Restoration Guide: Best Practices for Propagation and Population Enhancement. Arlington: The Nature Conservancy.

Kahui, V., Armstrong, C.W., Vondolia, G., 2016. Bioeconomic Analysis of HabitatFishery Connections: Fishing on Cold Water Coral Reefs. Land Economics. 92:2, 328343.

Kar, T.K., Matsuda, H., 2008. A Bioeconomic Model of a Single-Species Fishery with a Marine Reserve. Journal of Environmental Management. 86, 171-180.

Kiel, C.L. 2012., Acropora cervicornis Metrics for Quantifying the Size and Total Amount of Branching Coral. Open Access Thesis. Paper 342.

Kiel, C., Huntington, B.E., Miller, M.W., 2012. Tractable Field Metrics for Restoration and Recovery Monitoring of Staghorn Coral Acropora cervicornis. Endangered Species Research. 19, 171-76. doi: 10.3354/esr00474.

Knowlton N (2001) The future of coral reefs. Proc Natl Acad Sci U S A 98: 5419-5425. Krutilla, J.V., 1967. Conservation Reconsidered. American Economic Review. 57, 777786.

Kroloff, E.K.N., Heinen, J.T., Braddock, K.N., Rehage, J.S., Santos, R.O. 2019. Understanding the decline of catch-and-release fishery with angler knowledge: a key informant approach applied to South Florida bonefish. Environmental Biology of Fishes. 102:2, 319-328. 
Kuhlmann, D.H.H., 1988. The Sensitivity of Coral Reefs to Environmental Pollution. Ambio. 17, 13-21.

Lancaster, K., 1966. A New Approach to Consumer Theory. Journal of Political Economy. 74:132-147.

Lee, T.N., Williams, E., 1999. Mean Distribution and Seasonal Variability of Coastal Currents and Temperature in the Florida Keys with Implications for Larval Recruitment. Bulletin of Marine Science. 64:1, 35-56.

Leeworthy, V. R., 1991. Recreational Use Value for John Pennekamp Coral Reef State Park and Key Largo National Marine Sanctuary. Rockville, MD: National Oceanic and Atmospheric Administration.

Leeworthy, V.R., Bowker, J. M., 1997. Nonmarket Economic User Values of the Florida Keys/Key West. Silver Spring, MD: National Oceanic and Atmospheric Administration, Strategic Environmental Assessments Division. 41 p.

Le Quesne, W.J.F, Codling, E.A., 2009. Managing Mobile Species with MPAs: The Effects of Mobility, Larval Dispersal, and Fishing Mortality on Closure Size. ICES Journal of Marine Science. 66, 122-131.

Leujak W., Ormond R. F. G., 2007. Visitor Perceptions and the Shifting Social Carrying Capacity of South Sinai's Coral Reefs. Environmental Management. 39, 472-489.

Lirman, D., Thyberg, T., Herlan, J., Hill, C., Young-Lahiff, C., Schopmeyer, S., Huntington, B., Santos, R., Drury, C., 2010. Propagation of the Threatened Staghorn Coral Acropora cervicornis: Methods to Minimize the Impacts of Fragment Collection and Maximize Production.

Lirman, D., Schopmeyer, S., Galvan, V., Drury, C., Baker, A.C., Baums, I.B., 2014. Growth Dynamics of the Threatened Caribbean Staghorn Coral Acropora cervicornis: Influence of Host Genotype, Symbiont Identity, Colony Size, and Environmental Setting. Coral Reefs. 29, 729. doi:10.1007/s00338-010-0621-6.

Little, L. R., Punt, A. E., Mapstone, B. D., Begg, G. A., Goldman, B., Ellis, N., 2009. Different Responses to Area Closures and Effort Controls for Sedentary and Migratory Harvested Species in a Multispecies Coral Reef Line Fishery. ICES Journal of Marine Science. 66: 1931-1941.

Longley, W.H., Hildebrand, S.F., 1941. Systematic Catalogue of the Fishes of Tortugas, Florida with Observations on Color, Habits, and Local Distribution. Pap. Tortugas Lab. 34:1-331.

Luken, R.A., Johnson, F.R., Kibler, V., 1992. Benefits and Costs of Pulp and Paper Effluent Controls Under the Clean Water Act. Water Resources Research. 28:3, 665-674. 
Lynne, G.D., Conroy, P., Prochaska, F.J., 1981. Economic Value of Marsh Areas for Marine Production Processes. J. Environ. Econ. Manag. 8, 175-186.

MacNeil, M.A., Graham, N.A.J., Cinner, J.E., Wilson, S.K., Williams, I.D., Maina, J., Newman, S., Friedlander, A.M., Jupiter, S., Polunin, N.V.C., McClanahan, T.R., 2015. Recovery potential of the world's coral reef fishes. Nature 520, 341-344.

Manski, C., 1977. The Structure of Random Utility Models. Theory and Decision. 8, 229254.

McAllister, D.E., 1991. What is the Status of the World's Coral Reef Fishes? Sea Wind. $5,14-18$.

McClanahan, T.R., Mangi, S., 2000. Spillover of Exploitable Fishes from a Marine Park and its Effect on the Adjacent Fishery. Ecological Applications. 10, 1792-1805.

McClanahan, T.R., Graham, N. A. J., Calnan, J. M., MacNeil, M. A., 2007. Toward Pristine Biomass: Reef Fish Recovery in Coral Reef Marine Protected Areas in Kenya. Ecological Applications 4:1055-1067.

Micheli F., Saenz-Arroyo, A., Greenley, A., Vazquez, L., Espinoza Montes, J.A., Rossetto, M., De Leo, G.A., 2012. Evidence That Marine Reserves Enhance Resilience to Climatic Impacts. PLoS ONE 7(7): e40832. https://doi.org/10.1371/journal.pone.0040832

Millennium Ecosystem Assessment. 2005. Ecosystems and Human Well-Being. Washington, DC: Island Press. Available from http://www.millenniumassessment.org/documents/document.356.aspx.pdf.

Miller, M., Huntington, B., 2015. Coral, fish and other data to inform staghorn coral recovery in the Caribbean Sea from 2012-04-05 to 2014-07-28 (NCEI Accession 0127933). Version 1.1. NOAA National Centers for Environmental Information. Dataset. [Accessed March 13, 2017].

Miller, S., Chiappone, M., Rutten, L.M., Swanson, D.W., 2008. Population Status of Acropora Corals in the Florida Keys. Marine \& Environmental Sciences Faculty Proceedings, Presentations, Speeches, Lectures. 486. https://nsuworks.nova.edu/occ_facpresentations/486

Miller, M., Bourque, A., Bohnsack, J., 2002. An Analysis of the Loss of Acroporid Corals at Looe Key, Florida, USA: 1983-2000. Coral Reefs. 21:2, 179-182.

Moberg, F.F., Folke, C., 1999. Ecological Goods and Services of Coral Reef Ecosystems. Ecological Economics. 29, 215-233.

Molloy, P.P., McLean, I. B., Cote, I.M., 2009. Effects of Marine Reserve Age on Fish Populations: A Global Meta-Analysis. Journal of Applied Ecology. 46, 743-751. 
Mumby, P.J., Harborne, A.R., 2010. Marine Reserves Enhance the Recovery of Corals on Caribbean Reefs. PLoS ONE 5(1): e8657. doi:10.1371/journal.pone.0008657.

Mumby, P.J., Harborne, A.R., Williams, J., Kappel, C.V., Brumbaugh, D.R., Micheli, F., Holmes, K.E., Dahlgren, C.P., Paris, C.B., Blackwell, P.G., 2007. Trophic Cascade Facilitates Coral Recruitment in a Marine Reserve. Proceedings of the National Academy of Sciences 104:20 8362-8367. www.pnas.orgcgidoi10.1073pnas.0702602104.

Munro J.L., Williams, D.M. 1985. Assessment and Management of Coral Reef Fisheries: Biological, Environmental and Socioeconomic Aspects. Proceedings 5th International Coral Reef Congress, Tahiti. 4, 545-578.

NOAA (National Oceanic and Atmospheric Administration). 2007. Florida Keys National Marine Sanctuary Revised Management Plan.

NMFS (National Marine Fisheries Service). 2006. Endangered and Threatened Species: Final Listing Determinations for Elkhorn Coral and Staghorn Coral. 71 FR 26852.

NMFS. (National Marine Fisheries Service). 2008. Endangered and Threatened Species; Critical Habitat for Threatened Elkhorn and Staghorn Corals. 73 FR 72210.

NMFS (National Marine Fisheries Service). 2014. Fisheries Economics of the United States, 2012. U.S. Dept. Commerce, NOAA Tech. Memo. NMFS-F/SPO-137, 175p. Available at: https://www.st.nmfs.noaa.gov/st5/publication/index.html.

NMFS (National Marine Fisheries Service). 2015. Recovery Plan for Elkhorn (Acropora palmata) and Staghorn (A. cervicornis) Corals. Prepared by the Acropora Recovery Team for the National Marine Fisheries Service, Silver Spring, Maryland.

NPS (National Park Service). 2007. Research Natural Area Will Be Effective January 19, 2007. Dry Tortugas National Park. National Park Service. January 18, 2007. Retrieved 9-3-2016.

Neigell, J.E., Avise, J.C., 1983. Clonal Diversity and Population Structure in a ReefBuilding Coral, Acropora Cervicornis: Self Recognition Analysis and Demographic Interpretation. Evolution. 37, 437-453.

Pandolfi, J. M., 2002. Coral Community Dynamics at Multiple Scales. Coral Reefs. 21, 13-23.

Pandolfi, J.M., Jackson, J.B.C., 2006. Ecological Persistence Interrupted in Caribbean Coral Reefs. Ecological Letters. 9, 818-826.

Pendleton, L.H., 1994. Environmental Quality and Recreational Demand in a Caribbean Coral Reef. Coastal Management. 22, 399-404. 
Perry, C.T., Murphy, G.N., Kench, P.S., Smithers, S.G., Edinger, E.N., Steneck, R.S., Mumby, P.J., 2013. Caribbean-Wide Decline in Carbonate Production Threatens Coral Reef Growth. Nature Communications. 4:1402.

Peterson, C.H., Lubchenco, J., 1997. On the Value of Marine Ecosystems to Society. In: Daily, G.C. (Ed.), Nature's Services. Societal Dependence on Natural Ecosystems. Island Press, New York, pp. 177-194.

Pittman, S.J., Christenson, J., Caldow, C., Menza, C., Monaco, M., 2007. Predictive Mapping of Fish Species Richness Across Shallow-Water Seascapes in the Caribbean. Ecological Modeling. 204, 9-21.

Pratchett, M.S., Baird, A.H., McCowan, D.M., Coker, D.J., Cole, A.J., Wilson, S.K.,2009 Protracted declines in coral cover and fish abundance following climate-induced coral bleaching on the Great Barrier Reef. 11th International Coral Reef Symposium.

Principe, P. P., Bradley, P., Yee, S. H., Fisher, W. S., Johnson, E. D., Allen, P. Campbell, D. E., 2012. Quantifying Coral Reef Ecosystem Services. U.S. Environmental Protection Agency, Washington, DC, EPA/600/R-11/206.

Rehage, J.S., Santos, R. O., Kroloff, E. K. N., Heinen, J. T., Lai, Q. Black, B. D., Boucek, R. E., Adams, A.J. 2019. How has the quality of bonefishing changed over the past 40 years? Using local ecological knowledge to quantitatively inform population declines in the South Florida flats fishery. Environmental Biology of Fishes. 102, 2, pp 285-98.

Reid-Grant, K., Bhat, M., 2009. Financing Marine Protected Areas in Jamaica: An Exploratory Study. Marine Policy. 33,128-136.

Rinkevich, B., 1995. Restoration Strategies for Coral Reefs Damaged by Recreational Activities: The Use of Sexual and Asexual Recruits. Restoration Ecology. 3, 241-251. http://dx.doi.org/10.1111/j.1526-100X.1995.tb00091.x

Rogers, A., Blanchard, J.L., Mumby, P.J., 2014. Vulnerability of Coral Reef Fisheries to a Loss of Structural Complexity. Current Biology. 24, 1000-1005.

http://dx.doi.org/10.1016/j.cub.2014.03.026

Roberts, C.M., Bohnsack, J.A., Gell, F., Hawkins, J.P., Goodridge, R., 2001. Effects of Marine Reserves on Adjacent Fisheries. Science. 294: 5548, 1920-1923.

DOI: $10.1126 /$ science.294.5548.1920

Sano, M., 2004. Short-term Effects of a Mass Coral Bleaching Event on a Reef Fish Assemblage at Iriomote Island, Japan. Fisheries Science. 70:1, 41-46.

https://doi.org/10.1111/j.1444-2906.2003.00768.x 
Sathirathai, S., 1997. Economic Valuation of Mangroves and the Roles of Local Communities in the Conservation of Natural Resources: Case Study of Surat Thani, South of Thailand. International Development Research Centre, Ottawa, Ontario, Canada.

Sathirathai, S., Barbier, E., 2001. Valuing Mangrove Conservation in Southern Thailand. Contemporary Economic Policy. 19:2, 109-122.

Schopmeyer, S.A., Lirman, D., Bartels, E., Gilliam, D.S., Goergen, E.A., Griffin, S.P., Johnson, M.E., Lustic, C., Maxwell, K.E., Walter, C.S. 2017. Regional Restoration Benchmarks for Acropora cervicornis.” Coral Reefs 36 (2017): 1047-1057.

Selig, E.R., Bruno, J.F., 2010. A Global Analysis of the Effectiveness of Marine Protected Areas in Preventing Coral Loss. PLoS ONE 5(2): e9278. https://doi.org/10.1371/journal.pone.0009278.

Shafir, S., Van Rijn, J., Rinkevich, B., 2006. Steps in the Construction of an Underwater Coral Nursery, an Essential Component in Reef Restoration Acts. Marine Biology. 149, 679-687. http://dx.doi.org/10.1007/s00227-005-0236-6.

Shafir, S., Rinkevich, B., 2008. The Underwater Silviculture Approach for Reef Restoration: An Emergent Aquaculture Theme. In: Schwartz SH, editor. Aquaculture research trends. 1st ed. New York: Nova Scientific Publishers, Inc. p. 279-295.

Shaish, L., Levy, G., Gomez, E., Rinkevich, B., 2008. Fixed and Suspended Coral Nurseries in the Philippines: Establishing the First Step in the "Gardening Concept" of Reef Restoration. Experimental Marine Biology and Ecology. 358, 86-97. http://dx.doi.org/10.1016/j.jembe.2008.01.024.

Shinn, E.A., 1966. Coral Growth-Rate, An Environmental Indicator. Journal of Paleontology. 40:2, 233-240.

Sladek, J.S., Roberts, C.M., 1999. Fisheries Benefits and Optimal Design of Marine Reserve. Fishery Bulletin- National Oceanic and Atmospheric Administration 97(3):604616

Smith, S. G., Ault, J. S., Bohnsack, J. A., Harper, D. E., Luo, J., McClellan, D. B., 2011. Multispecies Survey Design for Assessing Reef-fish Stocks, Spatially Explicit Management Performance, and Ecosystem Condition. Fisheries Research, 109:1, 2541. https://doi.org/10.1016/j.fishres.2011.01.012.

Smith, S.V., 1978. Coral Reef Area and the Contributions of Reefs to Processes and Resources of the World's Oceans. Nature. 273:5659, 225-226.

Sobel, J., Dahlgren, C., 2004. Marine Reserves: A Guide to Science, Design, and Use. Washington, DC, USA: Island Press. 
Soong, K., Chen, T.I., 2003. Coral transplantation: Regeneration and Growth of Acropora Fragments in a Nursery. Restoration Ecology. 11, 62-71.

Sorokin, Y.I., 1993 (Ed.). Coral Reef Ecology. Ecological Studies 102. Springer Verlag, Berlin, pp. 4-28.

Southeast Fisheries Science Center (SEFSC). 2016. National Centers for Coastal Ocean Science (NCCOS). 2016. National Coral Reef Monitoring Program: Assessment of Coral Reef Fish Communities in the Florida Reef Tract. NOAA National Centers for Environmental Information. Dataset. [April 2017] South Florida Reef Visual Census. 2016. http://www.sefsc.noaa.gov/rvc_analysis20/samples/index.

Spalding, M.D., Grenfell, A.M., 1997. New Estimates of Global and Regional Coral Reef Areas. Coral Reefs. 16, 225-230.

Sponaugle, S., Lee, T., Kourafalou, V., Pinkard, D., 2005. Florida Current Frontal Eddies and the Settlement of Coral Reef Fishes. Limnology and Oceanography. 50, 1033-1048.

Spurgeon, J.P.G., 1992. The Economic Valuation of Coral Reefs. Marine Pollution Bulletin. 24: 11, 529-536.

Spurgeon, J.P.G., Lindahl, U., 2000. Economics of Coral Reef Restoration. In: Cesar H, editor. Collected Essays on the Economics of Coral Reefs. Kalmar, Sweden: CORDIO. pp. 125-136.

Stone, K., Bhat, M., Bhatta, R., Mathews, A., 2008. Factors Influencing Community Participation in Mangroves Restoration: A Contingent Valuation Study. Ocean \& Coastal Management. 51: 476-484.

Sudmeier-Rieux, K., Masundire, H., Rizvi, A., Rietbergen, S. (eds). 2006. Ecosystems, Livelihoods and Disasters. An Integrated Approach to Disaster Risk Management. Ecosystem Management Series No. 4. Gland, Switzerland: International Union for Conservation of Nature.

Sumaila, U.R., 1998. Protected Marine Reserves as Fisheries Management Tools: A Bioeconomic Analysis. Fisheries Research. 37, 287-296.

Syms C., Jones, G.P., 2000. Disturbance, Habitat Structure, and the Dynamics of a CoralReef Fish Community. Ecology. 81, 2714-2729

Thurstone, L., 1927. A Law of Comparative Judgement. Psychological Review. 4, 273286.

Toth, L.T., Van Woesik, R., Murdoch, T.J.T., 2014. Do No-Take Reserves Benefit Florida's Corals? 14 Years of Change and Stasis in the Florida Keys National Marine Sanctuary. Coral Reefs 33:3. DOI: 10.1007/s00338-014-1158-x 
Tunnicliffe, V., 1983. Caribbean Staghorn Coral Populations: Pre-Hurricane Allen Conditions in Discovery Bay, Jamaica. Bulletin of Marine Science. 33,132-151.

U.S. Congress. 2000. Coral Reef Conservation Act of 2000. [P.L. 106-562; 16 U.S.C. 6401 et seq; December 23, 2000] http://www.coris.noaa.gov/activities/actionstrategy/08_cons_act.pdf

U.S. Congress. 2001. National Marine Sanctuaries Act. Title 16, Chapter 32, Sections 1431 et seq. United States Code, as amended by Public Law 106-513, November 2000. http://sanctuaries.noaa.gov/library/national/nmsa.pdf.

U.S. Department of Commerce. 1995. Strategy for Stewardship Florida, Keys National Marine Sanctuary. Draft Management Plan/Environmental Impact Statement. Volume 13. National Oceanic and Atmospheric Administration.

U.S. Department of Commerce. 2008. Endangered and Threatened Species; Critical Habitat for Threatened Species; Final Rule., 50 CFR Parts 223 and 226.

Uyarra, M.C., Cote', I.M., Gill, J.A., Tinch, R., Viner, D., Watkinson, A.R., 2005. Island Specific Preferences of Tourists for Environmental Features: Implications of Climate Change for Tourism-Dependent States. Environmental Conservation. 32, 11-19.

Walker, B.K., Jordan, L.K.B., Spieler, R.E., 2009. Relationship of Reef Fish Assemblages and Topographic Complexity on Southeastern Florida Coral Reef Habitats. Journal of Coastal Research. 53, 39-48.

Waite, R., Burke, L., Gray, E., van Beukering, P., Brander, L., McKenzie, E., Pendleton, L., Schuhmann, P., Tompkins, E. 2014. Coastal Capital: Ecosystem Valuation for Decision Making in the Caribbean. Washington, DC: World Resources Institute. Accessible at: 〈http://www.wri.org/coastal-capital>.

Warren-Rhodes K., Sadovy Y.J., Cesar H., 2003. Marine Ecosystem Appropriation in the IndoPacific: A Case Study of the Live Reef Fish Food Trade. Ambio. 32(7), 481-488.

Weisbrod, B.A., 1964. Collective-Consumption Services of Individual-Consumption Goods. Quarterly Journal of Economics. 78, 471-47.

Wheaton, J.L., Jaap, W.C., 1988. Corals and Other Prominent Cnidaria of Looe Key National Marine Sanctuary, Florida. St. Petersburg, FL: Florida Marine Research Publications.

Wilkinson, C., 2008. Status of Coral Reefs of the World: 2008. Global Coral Reef Monitoring Network and Reef and Rainforest Research Centre, Townsville, Australia, 296 p. 
Wilkinson, C. R., 1996. Global Change and Coral Reefs: Impacts on Reefs and Human Cultures. Global Change Biology 2:6, 547 - 558. DOI: 10.1111/j.1365-

2486.1996.tb00066.x

Wilkinson, C., 2008. Status of Coral Reefs of the World. Global Coral Reef Monitoring Network and Reef and Rainforest Research Centre, Townsville, Australia, 296 p.

Wobeser, G.A., 1994. Investigation and Management of Disease in Wild Animals. New York, USA. 264 p.

Wright, M.G., 1994. An Economic Analysis of Coral Reef Protection in Negril, Jamaica. Williams College, Department of Environmental Studies.

Young, C.N., Schopmeyer, S., Lirman, D. 2012. A Review of Reef Restoration and Coral Propagation Using the Threatened Genus Acropora in the Caribbean and Western Atlantic. Bulletin of Marine Science. 88:4. DOI: 10.5343/bms.2011.1143

Zaneveld, J.R., Burkepile, D.E., Shantz, A.A., Pritchard, C.E., McMinds, R., Payet, J.P., Welsh, R., Correa1, A.M.S., Lemoine, N.P., Rosales, S. Fuchs, C., Maynard, J.A., Vega Thurber, R. 2016. Overfishing and Nutrient Pollution Interact with Temperature to Disrupt Coral Reefs Down to Microbial Scales. Nature Communications. 7:11833. DOI: 10.1038/ncomms11833. 
Chapter 2: Stated preference valuation of restocking and protecting the threatened staghorn coral on the Florida Reef Tract

\subsection{Introduction}

Staghorn coral (Acropora cervicornis) is a stony coral with antler-like cylindrical branches 0.25 to $5 \mathrm{~cm}$ in diameter that can form large thickets two to three meters tall and 30 meters long (NMFS, 2015). Staghorn is widely distributed throughout the western Atlantic, Caribbean, and Gulf of Mexico, including within the US jurisdictions of Puerto Rico and US Virgin Islands and four counties on the SE coast of Florida (Palm Beach, Broward, Miami-Dade, and Monroe) and, prior to the 1970s, was one of the most abundant structure building corals on shallow water Caribbean reefs for the past million years (Goreau, 1959; Geister, 1977; Adey, 1978; Jackson, 1992; Pandolfi and Jackson, 2001; Bruckner, 2002; Pandolfi, 2002;). Declines in staghorn abundance have been estimated as high as $97 \%$ regionally in the past four decades.

Staghorn coral's branching morphology provides essential habitat for fish and other organisms and a natural infrastructure protecting coastlines from damage associated with large tropical storms. Reef structural complexity has been linked to overall abundance and diversity of reef fishes (e.g., Grigg, 1994, Carpenter, et al., 1995; Lirman, 1999, Walker et al., 2009;), fish productivity, biomass, and reef carrying capacity (Warren-Rhodes et al., 2003; Graham et al., 2006). Fifty-percent of commercially important finfish species in Florida (e.g., amberjacks, groupers, hogfish, porgies, sea bass, snappers, tilefish, and triggerfish) use coral reef habitats during their lives, as do many recreationally targeted species (e.g., barracuda, dolphin, snook, tarpon, and trout) (Bruckner, 2002). 
Currently, no other structure building coral species on the FRT provides the same type of complex habitat supporting these specific ecosystem functions, therefore, it is possible the continued loss of staghorn corals will result in significant loss in coral reef function and structure (Acropora Biological Review Team, 2005). The ecological and socio-economic consequences as Florida's staghorn populations have died off and reefs bio erode may be substantial (Done, 1996; Jones and Syms, 1998; Pittman et al., 2007; Walker et al., 2009).

\subsection{Active restoration}

Coral reefs have been declining globally over the previous five decades from local and global anthropogenic stresses, including overfishing, bleaching, and disease (Hughes et al., 2003; MEA, 2005). Wilkinson (2008) estimated $19 \%$ of coral reefs have been lost in the past three decades and another $35 \%$ are threatened with loss by 2050 . Given the extent of the degradation, local conservation efforts and natural recovery may no longer be enough to preserve or restore the future health and integrity of the world's coral reefs (Goreau and Hilbertz, 2005). Practitioners and managers are increasingly relying on active coral reef restoration to counter patterns of decline and support the recovery of depleted coral populations and denuded reef ecosystems (Guzman, 1991; Rinkevich, 2005; Precht, 2006; Edwards, 2010; Johnson, et al., 2011; Schopmeyer et al., 2017). First practiced in the Indo-Pacific and Red Sea regions and now commonly used in Florida and the Caribbean, the "coral gardening" technique (Rinkevich, 1995; Johnson et al., 2011; Young et al., 2012; Schopmeyer, et al., 2017), entails removing live tissue from healthy coral colonies to be grown out in undersea nurseries (Rinkevich, 1995; Epstein et al., 
2003; Shafir and Rinkevich, 2008; Shaish et al., 2008; Young et al., 2012). After approximately six months to one year in the undersea nursery, colonies are removed and "outplanted" close to one another on denuded reefs, so they spawn and help reseed surrounding reefs. Restocking is expected to increase sexual reproduction and support the long-term recovery of wild staghorn populations and their genetic diversity (NMFS, 2015) and each outplanting site directly enhances live coral cover, reef structural complexity, habitat, and economic value.

Rapid growth (3-11.5 $\left.\mathrm{cm} \mathrm{yr}^{-1}\right)$ (Gladfelter, 1983), high first survivorship (Schopmeyer, et al., 2017) and ability to reproduce asexually through fragmentation make staghorn well suited for restocking programs (Highsmith, 1982; Federal Register, 2008; Lirman, et al., 2010; NMFS, 2015). Young, et al., (2012) identified more than 60 Acropora restoration projects in 14 Caribbean and island nations and, currently, tens of thousands of nursery-reared staghorn colonies are being transplanted annually on reefs along the FRT off SE Florida as part of a comprehensive regional restocking program.

\subsection{Marine reserves}

Although some of the leading threats to corals currently approach being unmanageable (e.g., disease, rising ocean temperature, and hurricanes), minimizing those threats that are manageable may reduce overall stress and strengthen corals ability to recover from episodic stress events (NMFS, 2015). Research suggests no-take marine reserves protecting corals from damage associated with fishing, anchoring, and other physical stressors may enhance coral survivorship, recruitment and growth (Mumby $e t$ al., 2007; Selig and Bruno, 2010). Potential costs to extractive users from prohibiting 
fishing on restocked reefs include congestion on the remaining fishing grounds, increase in fuel costs, and user conflicts, for example, however, marine reserves may stabilize or increase stocks, inside their boundaries and maybe outside (McClanahan and Mangi, 2000) leading to reduced variability in total catch levels (Lauck et al., 1998) or enhanced long-run total catch (Sanchirico, et al., 2002). Benefits to non-extractive users may include increased biodiversity and the ability to enjoy a healthier marine ecosystem. Scuba divers and snorkelers have shown preference to coral reefs with high complexity, diversity, and abundance of fish and other marine organisms (Leeworthy and Wiley, 1997; Bhat, 2002; Leeworthy, et al., 2004).

Research has also shown that the health of coastal ecosystems is also important to individuals who may never intend to use the areas, but still value their existence (Peterson and Lubchenko, 1997; Brander and van Beukering, 2013). These non-use values often make up most of the total economic value of environmental goods like coral reefs.

Limited studies have attempted to measure the economic values that the public attributes to the restoration and protection of coral reef ecosystems, and none have focused their analysis on the threatened staghorn coral or recovery efforts in SE Florida. Such benefit estimates are required to undertake comparisons of the costs and benefit of alternative staghorn coral management strategies. Additionally, benefits estimates may provide insight into the level of public support for the restoration and protection of Florida's coral reef ecosystems and the potential for alternative sources of financing for the restoration of Florida's coastal resources. 


\subsection{Estimating the benefits of restocking staghorn populations}

We used two attribute based stated preference methods to measure the total economic value of restocking and protecting populations of the threatened staghorn coral on the FRT. Stated preference methods are widely used in environmental valuation to collect information about respondent preferences for environmental amenities, typically through hypothetical scenarios presented in a survey format. The value a respondent places on a nonmarket environmental amenity can be derived from the maximum amount of money they would be willing to exchange for the delivery of that good or service, their maximum willingness-to-pay (WTP). Because SP techniques enable examination of preferences for levels of goods or services that differ from current levels or from levels that may have been observed previously, they are frequently the preferred approach for providing the economic valuation inputs required for cost-benefit analysis. Stated preference methods are also often the only approach to monetize the passive-use values of environmental amenities (Krutilla, 1967; Carson, et al., 1999). Because passive-use values contribute so much to the total economic value of some environmental goods, their examination is crucial for policymaking.

Contingent valuation (CV) and discrete choice experiments (DCE) are the most commonly used SP methods and generally contain choice sets, each comprised of a set of distinct hypothetical alternatives, from which respondents are requested to select their most preferred. For instance, alternatives are characterized by a set of attributes (one of which is generally cost), each taking one or more levels. The utility an individual derives from option $j$ can be denoted

$U_{j}(Q, I-A, X)=V_{j}(Q, I-A, X)+\varepsilon_{j}$ 
where $Q$ denotes a vector of alternative specific attributes, $I$ is the individual's disposable income, $A$ is the amount the individual would be willing to pay for the improved environmental quality (e.g., coral abundance), and $X$ is a vector of sociodemographic variables. The observable, or empirically measurable, component of utility is represented by $V_{j}(\cdot)$, while the unobservable stochastic component is denoted $\varepsilon_{j}$ and modeled as econometric error. An individual is assumed to choose the alternative from which they derive the greatest utility (de Palma et al., 2008). That is, they would be willing to pay an amount $A$ if,

$V_{1}\left(Q_{1}, I-A, X\right)+\varepsilon_{1} \geq V_{0}\left(Q_{0}, I, X\right)+\varepsilon_{0}$.

By extrapolating WTP amounts to the population(s) benefitting from a change in environmental quality, the total economic benefit from that change can be approximated. To examine whether preference elicitation technique had an impact on respondent preferences and WTP estimates, our survey instrument contained two elicitation formats: a single-bound dichotomous choice $\mathrm{CV}$ format through which respondents were requested to select their preferred alternatives when presented with scenarios consisting of the status quo (SQ) and each of three alternative management interventions; and a DCE format, through which respondents were presented with the four alternatives and requested to rank them from most preferred to least preferred. To fit respondents' preferences into a utility-theoretic framework and estimate WTP, we use two specifications of logit models, conditional (CL) and rank ordered (RL).

Stated preference methods are commonly used to examine public preferences and WTP for enhancements in the status environmental services including air quality (Carson, et al., 1990), rivers and lakes (Carson and Mitchell, 1993; Cooper et al., 2004; Hanley et 
al., 2006), coastal waters (Georgiou et al., 1998; Hanley et al., 2003), coral reef habitats (Bhat, 2003; Bishop, et al., 2011), and marine biodiversity (Stefanski and Shimshack, 2015). Although commonly used in environmental valuation, SP methods are not without criticism. Respondent preferences and, thus, WTP values are contingent on the (generally limited) information possessed by the respondent and provided by the survey. Another perceived shortcoming is that because respondents typically possess limited knowledge on the functions of resources such as corals and coral reefs, value estimates do not reflect all ecological values.

\subsection{The effect of risk perception on WTP}

Previous studies suggest individual WTP for enhanced delivery of environmental goods or services is guided by socioeconomic variables like education, income, gender and familiarity or use of the resource being valued. Studies have shown that individual WTP for environmental improvements may also be dependent on perceptions and attitudes towards the risks associated with the issue in question. For example, Sukharomana and Supalla (1998) found WTP for enhancements to groundwater quality increased with the perception of the risks from exposure to contaminants. Georgiou et al. (1998) concluded WTP for improvements to coastal water quality has a strong positive correlation with the perceived health risks from exposure to contaminated waters, and Veronesi et al. (2014) found that climate change perception had a significant impact on individual WTP to mitigate flooding induced wastewater overflows into rivers and lakes. Studies have also shown there are commonly significant disparities between individuals' perceptions of risk and objectively quantified risk (Kraus et al., 1992; Campbell et al., 
2002). Risks that are unfamiliar, uncontrollable, involuntary, irreversible, inequitably distributed, man-made, or catastrophic generally elicit the most concern (Slovic, 1987). Because perceptions of risk influence the decisions individuals make and frequently underlie disagreements over the optimal course of action, their consideration, and consideration of their underlying determinants, can help identify opportunities to inform people regarding actual risks and may reveal motives and barriers that stimulate or prevent action (Flynn, et al., 1994; Finucane, et al., 2000; Weber, Blais, \& Betz, 2002).

We derive estimates of various psychometric risk measures that characterize people's risk perception (RP), risk concern (RC), and support of risk-reduction (RR) action, and examine whether, and to what extent, risk perception affects their WTP to support efforts to restock and protect Florida's staghorn corals. Following Hunter et al. (2012), our study incorporates psychometric measures into a conventional utilitytheoretic model of non-market valuation and makes two notable contributions to the management of Florida's coastal resources. First, current research on the effects of risk perception is limited in coastal resource restoration and protection; results of our study provides insight on how different phases of risk evolution - RP, RC, and RR - influence the environmental value construct of individuals and WTP. Second, an understanding of the underlying determinants of risk perception can aid resource management agencies in efforts to engage the public and develop initiatives targeting awareness and literacy and, in turn, support for risk mitigation efforts like restocking and protecting staghorn corals (Vignola et al., 2013).

Research has shown geographic distance may also affect WTP for public goods with relatively large non-use values. Because distance impacts the use of environmental 
amenities (Sutherland and Walsh, 1985), empirical quantification of distance effects can be useful in decisions related to the aggregation of individual WTP values (Loomis, 1996) and decisions regarding sources of financing for environmental projects - for example, federal versus state or local funding (Concu, 2007). Multiple studies have discovered a negative relationship between distance and WTP values (Sutherland and Walsh, 1985; Loomis, 1996; Hanley et al., 2003) while others have found distance to be insignificant (e.g., Bateman and Langford, 1997; Pate and Loomis, 1997). Bateman and Langford (1997) found WTP to protect the Norfolk Broads, a destination for outdoor recreation in England, declined from its mean value as respondent distance increased from the Broads area. Pate and Loomis (1997) found distance influenced WTP for proposed programs to address environmental challenges in California and Sutherland and Walsh (1985) found distance and non-use values of water quality in Montana to be negatively correlated. Similarly, Georgiou et al. (1998) found a negative relationship between WTP to clean up a local river and geographic distance from respondents' residences to the project site. To examine whether geographic distance is a statistically significant determinant of respondent WTP for staghorn restocking and protection, we include the geographic distance from the centroid of the respondent's county of residence to Marathon, Florida in the Florida Keys as distance from as an explanatory variable in our valuation model. Finally, to enable examination into whether WTP estimates differ depending on the elicitation format and econometric analysis, we use two valuation methods: a conditional logit and rank-ordered logit. 


\subsection{Study background}

The FRT stretches approximately $350 \mathrm{~km}$ southwest from Soldier Key in Biscayne Bay to the Tortugas Banks in the Gulf of Mexico. About two-thirds of the FRT lies within Biscayne National Park and the Florida Keys National Marine Sanctuary (FKNMS), a 9,900-square nautical km marine protected area (MPA) that surrounds the Florida Keys. Proximity to the Miami metropolitan area and Florida Keys has subjected the reef ecosystem to decades of intense human use. After years of declining water quality, episodes of coral bleaching and diseases, coral cover loss, and falling reef fish stocks, the FKNMS was designated in 1990 to protect the Florida Keys' coastal and marine resources. Leeworthy and Bowker (1997) estimated 13.7 million visitor days, worth annual non-market use value of over $\$ 1.2$ billion, are spent annually in the Florida Keys, $75 \%$ of which is derived from natural resource-based activities like snorkeling, scuba diving and fishing. The inextricable linkages between the environment and economy make preservation and protection of existing resources critical to the future of the Florida Keys.

The dramatic loss of staghorn corals beginning in the 1970s has been largely attributed to white-band disease (Aronson and Precht, 2001), but linked to a multitude of inter-connected human induced and natural stressors. Today, most staghorn corals in the Florida Keys exist as isolated colonies or fragments on isolated patch reefs as opposed to their former abundance in deeper fore reef habitats (Miller et al., 2008). Recruitment of new colonies has been observed at various locations in the Keys, but new recruits appear to be dying prior to reaching maturity. Bruckner (2002) found mean staghorn coverage on the FRT to be $0.049 \%$ with little variation among the eight habitat types surveyed. 
Local fisheries have declined in productivity over the same period as staghorn corals; Twenty- three of 35 species of groupers, snappers, hogfish, and grunts have been chronically over-fished since the 1970s according to NMFS standards (Ault, 1998). In 1997, in response to user conflicts and resource degradation from concentrated visitor activity, 18 no-take sanctuary preservation areas (SPA), totaling $1.45 \mathrm{NM}^{2}$, were established in the FKNMS (NOAA, 2007). Additional, larger, protected areas were later established in the Dry Tortugas, a biologically rich area at the western end of the FKNMS. Almost $200 \mathrm{NM}^{2}$ in the Tortugas region is now closed to all fishing, however, in the time since designation of these protected areas, local staghorn populations have shown no evidence of natural recovery.

Having determined the threat of extinction was likely throughout all or much of staghorn's range, the NMFS listed staghorn coral as threatened under the ESA in 2006 (NMFS, 2006). The NMFS subsequently developed a recovery plan for the species with the goal of increasing the abundance and genetic variability of staghorn populations while reducing threats sufficiently to enable delisting. The plan details 24 recovery actions including improved fishing regulations (e.g., restricting fishing in areas near staghorn colonies) and active population enhancement through the implementation of a comprehensive restocking plan.

\subsection{Methodology}

Internet surveys have become common in research for the enhanced access and opportunities for data collection they offer along with the ability to quickly and conveniently administer complex instruments without personal interviewers or 
simultaneous interaction (Bishop et al., 2011). We administered a household survey in June 2017 through the Qualtrics online platform to elicit the preferences of residents of the Southeastern United States for restocking and protecting Florida's staghorn coral populations. Households in Florida, Alabama, Georgia, and Mississippi $(n=3,135)$ were randomly selected from the Qualtrics panel to complete the survey. Of the 3,135 surveys initiated by respondents, 1,260 were completed in full. The survey contained a question to test whether respondents were reading the questions and providing thoughtful answers. Responses from respondents who "failed" this test question and completed the survey in less than the median respondent time were removed from consideration. We retained 1061 surveys for further analysis.

The questionnaire included four sections. The first section contained: (i) an explanation of the purpose of the survey, (ii) questions regarding respondents' familiarity and experience with coral reefs, and (iii) videos discussing ecosystem services provided by staghorn corals, status and threats facing staghorn corals and the FRT, and active efforts to recover lost staghorn populations. The second section included a brief recap of the status, threats, and efforts to restock staghorn populations discussed in the videos; The third section contained the choice model, and fourth section contained questions related to WTP motivations, risk perception, and socio-demographic characteristics. The 14 risk perception questions, following the psychometric paradigm developed by Slovic (Slovic, 1987), were rated on a five-point Likert scale. The first two sets of five questions evaluated respondents' perception of the anthropogenic risks facing Florida's coral reefs [Risk Perception (RP) variables] and respondents' concern [Risk Concern (RC) variables], respectively. The final four questions evaluated respondents' attitudes toward 
intervention or regulation [Risk Reduction or Regulation (RR) variables]. The data were tested for internal consistency of the questions in each group. Cronbach alpha values for $\mathrm{RP}, \mathrm{RC}, \mathrm{RR}$ groups and all questions combined were $.93, .53, .66$, and .87 , respectively for the rank ordered logit dataset and $.92, .50, .69$, and .87 for the conditional logit dataset respectively, indicating an acceptable level of internal consistency.

In the choice model section, two techniques are used to elicit respondent preferences for four proposed staghorn coral management alternatives (SQ, and three alternative management interventions). One-half of respondents were randomly selected to rank the four management alternatives most preferred to least preferred and one-half were presented a dichotomous discrete choice format wherein the respondent was requested to choose sequentially between the SQ and each of the three alternatives with positive action. The purpose of using the two valuation methods was to allow examination into whether the WTP estimates differ depending on elicitation format and econometric analysis.

\subsection{Valuation scenarios}

In the survey instrument, each alternative was characterized in terms of its features or "attributes". Described attributes include: (i) the number of staghorn colonies outplanted on the FRT annually and estimated coral cover resulting from the outplantings after 30 years, (ii) the area of new marine reserves protecting outplanted corals, and (iii) cost of each alternative to the respondent.

Attributes had two levels each: the SQ and a positive intervention. As summarized in Table 12, the outcomes were described in terms of staghorn area on the 
FRT after 30 years. The specific spatial and biological parameters that characterized the alternatives were simulated using the staghorn coral growth model described in Chapter one. To account for substitution and income effects (Arrow et al., 1993), the survey contained verbiage advising respondents to keep in mind that paying for the intervention would leave less funds for other things that the respondent's household may have needed. The proposed payment vehicle was an additional annual tax added to the annual federal income tax obligation. The sample included two sub-sets of respondents, those who had visited a coral reef in Florida in the past three years and those who had not, allowing us to determine whether the non-use component of the total coral economic valuation was significant. Questions also examined whether respondents understood the alternative programs and confidence in their potential effectiveness.

The choice model section of the survey contained a SQ alternative which assumed the current level of outplanting (approximately 50,000 colonies $\mathrm{yr}^{-1}$ ) would continue for at least 30 years with no new marine reserves to protect outplanted colonies. In addition to the SQ, there were three alternative programs in the survey: (1) increase staghorn outplants on the FRT from the current annual average of approximately 50,000 to $300,000,(2)$ implement no-take marine reserves to protect the 50,000 colonies currently outplanted every year, (3) increase staghorn outplants on the FRT from the current annual average of approximately 50,000 to 300,000 and implement no-take marine reserves to protect outplanted corals. 


\subsection{Respondents' risk perception}

Because of multi-collinearity, the responses to the 14 RP questions could not be used as explanatory variables in the WTP model. To identify the factors accounting for the most variation in the observed responses and enable their inclusion in the WTP model, we conducted exploratory factor analysis (EFA) on the $14 \mathrm{RP}$ variables. The varimax (orthogonal) rotation was used to extract the factors (DiStefano, 2009). Results suggested two meaningful factors with eigenvalues $>1$; variables were assumed to load on a factor if the loading exceeded 0.5 . Using these criteria, we associated the following statements, or attitudes, with the factors they loaded on (1) "willingness to reduce risk" (WRR) and (2) "unwillingness to worry about risks" (UWR).

Regression factor scores were predicted for the two factors with eigenvalues $>1$ using a least squares regression approach (Thurstone, 1935) in which the regression equation independent variables are the standardized observed values of the items (i.e., respondent responses) in the estimated factors. These independent variables are weighted by regression coefficients calculated as the product of the inverse of the observed variable correlation matrix and matrix of factor loadings (DiStefano, 2009). Regression factor scores predict the location of each respondent on the factor and have been shown to be unbiased when used as independent variables in regression models (Devlieger, Mayer, and Rosseel, 2016). A similar approach was used to examine the public's WTP for enhancements to lake water quality (Cooper et al., 2004), reductions in risks from exposure to cyanobacterial blooms (Hunter et al., 2012), and recovery of endangered species (Aldrich et al., 2007). 


\subsection{Econometric models}

We apply the standard conditional logit model (McFadden, 1973) to the dichotomous choice dataset and rank ordered logit, a generalization of the CL, to the dataset of ranked alternatives (Hausman and Ruud, 1987). Conditional logit models allow choices among alternatives to be modeled as a function of the attributes of the alternatives in the choice set as well as the characteristics of the individual making the choice. In the standard CL model, individuals are assumed to select the alternative from the choice set that provides the greatest utility. Following the random utility model in equation (2), in the standard CL, the probability of a respondent saying "yes" to paying amount $A$ is

$$
\begin{aligned}
\operatorname{Prob}(Y e s \text { to } A) & =\operatorname{Prob}\left[V_{1}\left(Q_{1}, Y-A, X\right)+\varepsilon_{1} \geq V_{0}\left(Q_{0}, Y, X\right)+\varepsilon_{0}\right] \\
= & \operatorname{Prob}\left[V_{1}\left(Q_{1}, Y-A, X\right)-V_{0}\left(Q_{0}, Y, X\right) \geq \varepsilon_{0}-\varepsilon_{1}\right] \\
= & F n(n) \\
= & F n(\Delta V)
\end{aligned}
$$

where $n=\varepsilon_{0}-\varepsilon_{1}$ and $\Delta V=V_{1}\left(Q_{1}, Y-A, X\right)-V_{0}\left(Q_{0}, Y, X\right)$, the difference in utility between the two alternatives, and $F_{n}(\Delta V)$ is the cumulative probability density function. Per the logit model

$$
\begin{aligned}
& F_{n}(\Delta V)=\frac{1}{1+e^{-\Delta V}} \\
& F_{n}(\Delta V(A))=\frac{1}{1+e^{-\Delta V(A)}}
\end{aligned}
$$

The observable component of utility $V_{k}$ for each respondent is specified to be linear in parameters, such that

$U_{r i}=\sum_{k} \beta_{r i k} X_{r i k}+\varepsilon_{r i}$ 
where $X_{r k}$ is a vector of $K$ choice-related characteristics consisting of individual characteristics and observed attributes, and $B_{r k}$ is a vector of $K$ coefficients to be estimated. In the RL, the probability individual $i$ will select program $k$ in round one of the ranking process can be denoted

$$
\begin{aligned}
& \text { Prob(individual i chooses program } k)=P_{i k}=P\left(U_{i k}>U_{i j}, \text { for all } j \neq k\right) \\
& =P\left(V_{i k}+\varepsilon_{i k}>V_{i j}+\varepsilon_{i j}, \forall j \neq k\right) \\
& =P\left(\varepsilon_{i j}-\varepsilon_{i k}<V_{i k}-V_{i j}, \forall j \neq k\right)
\end{aligned}
$$

In this study, respondents make a choice among four alternatives: the SQ and three with some increase in the abundance of staghorn corals compared to the SQ. This increased abundance of staghorn coral can be realized at a cost to be paid as an addition to the respondents' annual federal income tax obligation, and the cost of maintaining current abundances of staghorn corals is zero. From this, equation 18 can be generally formulated as

$U_{i j}=\left(\beta_{M R} M R_{j}+\beta_{C} C_{j}+\beta_{M R C} M R_{j} C_{j}\right) X_{i}+\varepsilon_{i j}$

where $i$ denotes individual respondents $(i=1 \ldots n) ; j$ denotes the four program alternatives in the survey $(1=$ SQ, $2=$ Marine Reserve Program, $3=$ Staghorn Restocking Program, and $4=$ the combination of programs 2 and 3 ); $X_{i}$ is a $k \times 1$ vector of individual specific variables, including a " 1 " to enable consideration of alternative-specific constant (ASC) terms; $M R_{j}$ and $C_{j}$ are scalar variables indicating whether or not marine reserves or staghorn restocking programs appear in alternative $j$; and $\beta_{M R}, \beta_{C}$, and $\beta_{M R C}$ are $1 \times k$ vectors of the marginal contributions to individual utility from the respective programs.

Seven specifications of this model were estimated to explore the effects of individuals' socio demographic characteristics and risk perceptions on WTP in a step- 
wise fashion. Model 1 is specified with the full set of individual specific covariates interacted with the ASC.

$U_{i j}=\beta_{M R} M R_{j}+\beta_{C} C_{j}+\beta_{M R C} M R_{j} C_{j}+\beta_{A e d u} A_{i j} e d u_{i}+\beta_{A i n c} A_{i j} i n c_{i}+$

$\beta_{\text {Atimes }} A_{i j}$ times $_{i}+\beta_{\text {Aage }} A_{i j}$ age $+\beta_{\text {Agender }} A_{i j}$ gender $+\beta_{\text {AFLres }} A_{i j}$ FLres +

$\beta_{A W R R} A_{i j} W R R+\beta_{A U W R} A_{i j} U W R+\beta_{\text {Aenviro }} A_{i j}$ enviro $+\beta_{\text {Adist }} A_{i j} d i s t+\varepsilon_{i j}$

where $A$ is ASC, $\beta_{\text {Aedu }}$ is the vector of coefficients from the interaction of ASC and Edu, $\beta_{\text {Ainc }}$ is the vector of coefficients to the interaction of ASC and Income, $\beta_{\text {Atimes }}$ is the vector of coefficients to the interaction of ASC and times, $\beta_{\text {Aage }}$ is the vector of coefficients to the interaction of ASC and Age, $\beta_{\text {Agender }}$ is the vector of coefficients to the interaction of ASC and gender, $\beta_{F L r e s}$ is the vector of coefficients to the interaction of ASC and flres, $\beta_{A W R R}$ is the vector of coefficients to the interaction of ASC and WRR, $\beta_{A U W R}$ is the vector of coefficients to the interaction of ASC and UWR, $\beta_{\text {Aenviro }}$ is the vector of coefficients to the interaction of ASC and enviro, and $\beta_{\text {Adist }}$ is the vector of coefficients to the interaction of ASC and distance.

Model 2 is the original choice model with the distance variable removed, Model 3 is Model 2 with the variable reflecting the number of times the respondent visited a coral reef in the previous three years removed, Model 4 is Model 3 with the age variable removed, Model 5 is Model 4 with the variable resident variable removed, Model 6 is Model 5 with education variable removed, and Model 7 is Model 6 with the WRR and UWR variables removed. The model variables for the CL and RL models are defined and described in Tables 13 and 19, respectively and estimation results presented in Table 16 and Table 26, respectively. In addition to the final model presented here, we explored several model specifications and found that some led to results that differed significantly 
from our final model. Specifically, early runs of the CL model included the variables for the number of times a respondent has visited a coral reef, age, gender, distance, question sequence and whether the respondent was a Florida resident, but these were found to be insignificant and removed from the final model to improve estimation efficiency; A similar procedure was followed with the RL models. Estimation of mean WTP is not significantly impacted by the inclusion or exclusion of the omitted covariates. The conditional logit and rank order logit model variables are summarized in Tables 16 and 25 , respectively.

\subsection{Results}

\subsection{Descriptive statistics}

Examination of respondent demographic information for the two sets of respondents (Tables 14 and 20), confirms, other than gender, the samples are generally representative of the national and respective state populations. The mean age of US and Florida residents is 38 and 41years old, respectively, compared to mean of 35 and 36 and median of 31 and 33 years for the CL and RL datasets, respectively. The distribution of race across respondents is representative of the SE United States. In Florida, where approximately one-half of the survey respondents resided at the time the survey was administered, the population is $16.9 \%$ black, $54.1 \%$ white, and $25.6 \%$ Hispanic. Compared only to the Florida population, whites appear to be overrepresented and Hispanics underrepresented among respondents, however, in AL, MS, an GA, where onehalf of respondents resided, whites and Hispanics make up a smaller percentage and blacks a larger percentage of the overall population, likely explaining much of the difference. Mean respondent per capita income is $\$ 25,414$ and $\$ 26,803$ for the RL and 
CL datasets, respectively, compared to $\$ 29,829$ nationally and between $\$ 21,651$ $\$ 27,598$ for the states of FL, GA, MS, and AL. Nationally, $87.0 \%$ and $30.3 \%$ of individuals over the age of 25 graduated from high school or higher and college or higher, respectively. Of the CL dataset respondents over the age of 25, 68.44\% were graduates of high school or higher, and $44.27 \%$ were graduates of college or higher; $64.89 \%$ of the RL respondents were graduates of high school or higher and $47.84 \%$ graduates of college or higher. In both samples, the proportion of female respondents is dramatically higher than in the US population.

4.2 Rank ordered logit risk perception data and factor analysis results

Results of the psychometric questions are presented in Table 22. Respondents indicated they are not strongly convinced that Florida's coral reefs have deteriorated dramatically in recent decades or that the risks to Florida's coral reefs and fisheries will continue to increase into the future, with mean scores of 3.93 and 3.81, respectively. Respondents indicated they were relatively comfortable with the level of risks facing Florida's coral reefs and marine resources, with a mean score of 3.71, but indicated they are uncertain whether future generations will address the risks faced by Florida's reefs appropriately (mean score of 2.67) or whether the health of Florida's coral reefs is managed by the relevant authorities (mean score of 2.97). On average, respondents indicated they were between "moderately" and "very" concerned about the health and future of Florida's coral reefs and coastal resources with mean scores ranging from 3.533.78. Overall, results suggest moderately high level of support for regulatory action (mean score 4.05) as well as a moderately high sense of individual responsibility for contributing toward the protection and enhancement of coral reefs (mean score 3.90). 
Examination of risk responses across different demographic groups suggests that the respondent's gender and whether they were a Florida resident had no significant impact on their RP, RC, or RR . Overall, level of education is positively correlated with RP, RC, and RR. Notably, income is a statistically significant determinant of RR, but not of $\mathrm{RP}$ and $\mathrm{RC}$ while the number of times a respondent has visited a coral reef is a determinant of RP and RC, but not RR. Race was a statistically significant determinant of $\mathrm{RP}$ and RR, but not RC. Responses to the psychometric questions were examined further using exploratory factor analysis (EFA). Kaiser-Meyer-Olkin values indicated that all 14 variables were suitable for inclusion (all values $>0.60$, overall value 0.9123 ). Two meaningful factors (eigenvalues >1) were extracted through a varimax (orthogonal) rotation, suggesting respondents' RP, RC, and RR were determined by two underlying, or latent, factors. The groups of variables contained in the two factor groupings were labeled "willingness to reduce risk" (WRR) and "unwillingness to worry about risk" (UWR) for factors one and two, respectively. Observed risk variables used in the EFA and their corresponding loadings are represented in Table 24. All five of the RP questions are contained in factor one and had large, positive loadings (>0.7959) on that factor, indicating it describes the variation in those variables adequately. Two of the five RC, and three of the four RR, questions are contained in factor one. The RC questions in this factor elicit the level of concern for the general health of Florida's coral reefs and for coral bleaching associated with climate change; the three RR questions express support for the protection and enhancement of Florida's coral reefs.

Factor two contains questions that address specific threats, (i.e., overfishing, marine pollution, biodiversity, and physical damage to coral reefs and sea grass beds) that 
are commonly understood by the public and generally considered to be manageable. Also contained in factor two was the statement: "The relevant public agencies will manage Florida's coral reefs without my contribution to the effort", suggesting that whether and to what extent a threat is perceived to be locally manageable may be correlated with respondents' confidence in the ability of public agencies to manage them and, therefore, a reduced $R R$.

To examine correlation between the three risk categories, Pearson's correlation coefficients were estimated for their sums of scores. The correlation coefficient between $\mathrm{RP}$ and $\mathrm{RC}$ of $0.3569(\mathrm{p}<0.001)$ exhibits a moderately strong and statistically significant positive correlation between RP and RC. As would be expected, the correlation coefficient between $\mathrm{RC}$ and $\mathrm{RR}$ is strong $(0.6741, \mathrm{p}<0.001)$ and positive. This supports the hypothesis that respondents who indicate a high level of concern for the risks facing Florida's coral reefs are more likely to support and express WTP to protect coastal resources and mitigate risk. Interestingly, the correlation between RP and RR $(0.5104, p$ $<0.001)$ is stronger than the correlation between RP and RC, suggesting a direct pathway from RP and RR for some respondents.

\subsection{Respondents' WTP and effect of risk perception}

The results of the CL model are presented in Table 16. WTP was estimated

$$
W T P_{i j}=\frac{-(\widehat{\beta}) X_{i}}{\widehat{\beta}_{c o s t}, j}
$$

where $\hat{\beta}$ is a vector of coefficients for the individual specific covariates, and $\hat{\beta}_{c o s t, j}$ is the estimated cost coefficient for program $j$. The sign of the cost coefficient is negative for all three alternatives as expected but significant only for the marine reserve program, 
implying a measurable propensity to choose only the marine reserve program (and not the restocking program or the alternative combining the restocking and marine reserve program) over the SQ apart from any propensity explained by the other model covariates. Because only the cost coefficient for the marine reserve program was significant, WTP was estimated only for the coral and combined alternatives. The coefficient for distance was not significant for any of the three alternatives, however, we estimated WTP with and without distance as a covariate for comparison. Household WTP estimates are presented in Tables 17 and 18. Both risk-related factor variables were positive and statistically significant, indicating respondents' attitudes toward and perceptions of the risks facing Florida's coral reefs had a positive and significant impact on the probability of choosing all three of the programs to restore and protect staghorn coral populations. The coefficient for income was positive for all three programs, but significant only for the coral restocking program, implying income has a positive and significant impact on the probability of a respondent selecting the coral restocking program but that no significant income effects exist for the combined and marine reserve programs. The coefficient for enviro is positive for all three alternatives but significant only for the combined program, implying that whether someone self identifies as a "strong" or "very strong" environmentalist affects the probability of whether they select the combined program but not the coral restocking or marine reserve programs, individually. The coefficient for education is significant and positive for the marine reserve and both programs, implying it is not a significant determinant of whether the respondent selected the coral restocking program. The coefficient for the variable indicating question 
sequence was not significant, suggesting the order in which the alternatives were presented to respondent was not a significant determinant of respondent preferences.

Table 12. Alternative programs and outcomes

\begin{tabular}{llll}
$\begin{array}{l}\text { Management } \\
\text { alternative }\end{array}$ & $\begin{array}{l}\text { Annual } \\
\text { outplants }\end{array}$ & $\begin{array}{l}\text { Marine reserves } \\
\text { to Protect } \\
\text { outplants? }\end{array}$ & $\begin{array}{l}\text { Staghorn area } \\
\text { after 30 yrs. } \\
\text { (sq. miles) }\end{array}$ \\
\hline Status quo & 50,000 & No & .5 \\
Restocking & 300,000 & No & 4 \\
Marine reserves & 50,000 & Yes & 1 \\
Combined & 300,000 & Yes & 5.5 \\
\hline
\end{tabular}


Table 13. Definition of variables included in the conditional logit model.

\begin{tabular}{|c|c|}
\hline Alternative-specific variables & Variable definition \\
\hline Coral & $\begin{array}{l}\text { A variable indicating the restocking } \\
\text { program appeared in the chosen } \\
\text { alternative }\end{array}$ \\
\hline Marine reserve & $\begin{array}{l}\text { A variable indicating the marine reserve } \\
\text { program appeared in the chosen } \\
\text { alternative }\end{array}$ \\
\hline Cost & $\begin{array}{l}\text { The cost to the household of the } \\
\text { alternative }\end{array}$ \\
\hline Individual-specific variables & Variable definition \\
\hline WRR & Risk Factor Score 1 \\
\hline UWR & Risk Factor Score 2 \\
\hline Enviro & $\begin{array}{l}\text { A dummy variable that equals } 1 \text { if the } \\
\text { respondent indicated they were either a } \\
\text { "very strong" or "strong" environmentalist }\end{array}$ \\
\hline Edu & $\begin{array}{l}\text { A variable indicating the level of } \\
\text { respondent education. } 1=\text { Less than high } \\
\text { school, } 2=\text { HS grad, } 3=\text { Some College, } \\
\text { 4=College Grad. }\end{array}$ \\
\hline Inc & Respondent household per capita income \\
\hline Age & Respondent age \\
\hline Dist & $\begin{array}{l}\text { Distance from location survey was } \\
\text { completed to the Florida Keys Marathon } \\
\text { International Airport, located } \\
\text { approximately in the middle of the Keys } \\
\text { island chain. }\end{array}$ \\
\hline Gender & Respondent gender \\
\hline
\end{tabular}


Table 14. Conditional logit respondent demographics

\begin{tabular}{lcccccc}
\hline & $n$ & Mean & Median & Std. Dev. & Min & Max \\
\hline Age & 529 & 34.59 & 31 & 13.65 & 16 & 79 \\
Household size & 529 & 2.75 & 3 & 1.27 & 1 & 5 \\
Per capita income (\$000's) & 529 & 26.80 & 17.50 & 28.07 & 10 & 250 \\
Gender & $n$ & $\%$ & & & & \\
$\quad$ Female & 365 & 69 & & & & \\
$\quad$ Male & 164 & 31 & & & & \\
Race/Ethnicity & $n$ & $\%$ & & & & \\
$\quad$ White & 312 & 58.98 & & & & \\
$\quad$ Hispanic & 75 & 14.18 & & & & \\
$\quad$ Black or African-American & 121 & 22.87 & & & & \\
$\quad$ Other & 21 & 3.97 & & & & \\
Education & $n$ & $\%$ & & & & \\
$\quad$ Less than high school & 20 & 3.78 & & & & \\
High school graduate & 143 & 27.03 & & & & \\
Some college & 157 & 29.68 & & & & \\
College graduate & 209 & 39.51 & & & & \\
\hline
\end{tabular}

Table 15. Summary of variables included in the final conditional logit model $(n=529)$

\begin{tabular}{lllll}
\hline Variable & Mean & Standard & Min. & Max. \\
\hline Coral cost (\$/household) & 118.0 & 53.829 & 50 & 200 \\
MR cost (\$/household) & 106.7 & 43.732 & 40 & 160 \\
Both cost (\$/household) & 213.3 & 64.832 & 85 & 340 \\
WRR & 0.000 & 0.9693 & -3.8920 & 4.4382 \\
UWR & 0.000 & 0.8258 & -2.8092 & 2.5058 \\
Enviro & 0.279 & 0.4493 & 0 & 1 \\
Education & 3.049 & 0.9031 & 1 & 4 \\
Income (\$K/person) & 26.80 & 28.069 & 2 & 250 \\
\hline
\end{tabular}


Table 16. Results from conditional logit

\begin{tabular}{llll}
\hline & Both & Marine Reserve & Coral \\
\hline Cost & -0.0016 & $-0.0053^{* * *}$ & -0.0022 \\
Enviro & $(0.0011)$ & $(0.0018)$ & $(0.0014)$ \\
& $0.6336^{* * *}$ & 0.1452 & 0.2942 \\
WRR & $(0.2448)$ & $(0.2310)$ & $(0.2220)$ \\
& $0.7551^{* * *}$ & $0.7069^{* * *}$ & $0.5730^{* * *}$ \\
UWR & $(0.1138)$ & $(0.1127)$ & $(0.1079)$ \\
& $0.3992^{* * *}$ & $0.4327^{* * *}$ & $0.3289^{* * *}$ \\
Edu & $(0.1254)$ & $(0.1186)$ & $(0.1150)$ \\
& $0.1402^{*}$ & $0.1414^{*}$ & -0.0044 \\
Income & $(0.0847)$ & $(0.0737)$ & $(0.0685)$ \\
& 0.0045 & 0.0037 & $0.0071^{*}$ \\
Observations & $(0.0038)$ & $(.00367)$ & $(0.0037)$ \\
Wald chi ${ }^{2}$ & 529 & 529 & 529 \\
Prob $>$ Chi ${ }^{2}$ & 79.68 & 64.13 & 50.17 \\
Log-likelihood & 0.0000 & 0.0000 & 0.0000 \\
\hline \multicolumn{2}{c}{ Standard error in parentheses; ${ }^{*} \mathrm{p}<0.10,{ }^{* *} \mathrm{p}<0.05,{ }^{* * *} \mathrm{p}<0.01$}
\end{tabular}

Table 17. Household WTP without distance as a covariate

\begin{tabular}{lcccccc}
\hline \multicolumn{1}{c}{ Model } & WTP & Std. Err. & z & \multicolumn{2}{c}{ Prob $>|z|$} & \multicolumn{2}{c}{$95 \%$ Conf. Interval } \\
\hline Both & $457.24^{*}$ & 187.19 & 2.44 & 0.015 & 90.35 & 824.13 \\
Marine reserve & 107.89 & 17.29 & 6.24 & 0.000 & 74.01 & 141.78 \\
Coral & $115.33^{*}$ & 40.02 & 2.88 & 0.004 & 36.88 & 193.78
\end{tabular}

*Logit model cost coefficient not statistically significant 
Table 18. Household WTP with distance as a covariate

\begin{tabular}{|c|c|c|c|c|c|c|}
\hline \multirow[t]{2}{*}{ Model } & \multirow{2}{*}{$\begin{array}{c}\text { WTP } \\
441.09^{*}\end{array}$} & \multirow{2}{*}{$\begin{array}{l}\text { Std. Err. } \\
168.09\end{array}$} & \multirow{2}{*}{\begin{tabular}{r|}
$\mathrm{z}$ \\
2.62
\end{tabular}} & \multirow{2}{*}{$\begin{array}{l}\text { Prob }>|z| \\
0.009\end{array}$} & \multicolumn{2}{|c|}{$\begin{array}{l}95 \% \text { Conf. } \\
\text { Interval }\end{array}$} \\
\hline & & & & & 111.64 & 770.54 \\
\hline Reserve & 105.89 & 18.27 & 5.79 & 0.000 & 70.07 & 141.71 \\
\hline & $112.62^{*}$ & 41.25 & 2.73 & 0.006 & 31.77 & 193.47 \\
\hline
\end{tabular}

${ }^{*}$ Logit model cost coefficient not statistically significant

\subsection{Rank ordered logit}

We estimated seven rank ordered logit models in which individual-specific variables were interacted with the ASC terms to generate variation across alternatives necessary for estimation. Summary statistics for model variables are presented in Table 21. Results of the RL model are presented in Table 26 and discussed below. A Wald test on the eight final model covariates cannot reject their joint significance $\left(\mathrm{X}^{2}(21)=220.12\right.$, $\mathrm{p}<0.001)$. The pseudo simulated log-likelihood at model convergence is:-1564.776.

Model one contains all socio demographic variables generated through the survey instrument interacted with the indicator terms. In subsequent models, we removed the interaction variables containing dist, times, age, flres, gender, and educate one at a time, re-estimating the model with each removal. As expected from economic theory, the coefficient for bid is negative and significant in all seven models. Household WTP was estimated

$$
W T P_{i j}=\frac{-\left(\beta_{C} C_{j}+\beta_{M R} M R_{j}\right) X_{i}}{\beta_{c o s t}, j}
$$


where $i$ represents the individual survey respondents $(i=1 \ldots n) ; j$ represents the four program options in the survey $(1=\mathrm{SQ}, 2=$ the marine reserve program, $3=$ the staghorn restocking program, and $4=$ the combination of programs 2 and 3$), C_{j}$ and $M R_{j}$ are scalar variables indicating whether stocking or marine reserves are in alternative $j, X_{i}$ is a vector of individual specific variables, and $\beta_{c o s t, j}$ is the coefficient for the cost of program $j$.

Household WTP was estimated using all seven models to examine the impact of individual covariates on mean preferences; WTP estimates for the restocking program, marine reserve and combined programs ranged from $\$ 94.74$ to $\$ 179.01, \$ .03$ to $\$ 96.60$, and $\$ 96.00$ to $\$ 275.61$, respectively, and reflect substantial variation across models. The insignificance of the variable representing the number of times a respondent had visited a coral reef implies non-users maintain a significant WTP for coral restoration and protection. The coefficient for the $A S C$ term for the coral program is positive and insignificant in every model other than in model six, where it is positive and significant, and the coefficient for the indicator variable for marine reserve is negative and insignificant in every model, other than in model six where it is positive and insignificant. These results imply that other than in model six, there is no measurable propensity to select an alternative including restocking or marine reserves over the SQ beyond any propensity explained by the other model covariates. The coefficients for the variables of income and enviro interacted with coral are positive and significant implying that respondent income and whether they identify themselves as a "strong environmentalist" or "very strong environmentalist" has a significant and positive impact on the probability they select a program with coral in it. The coefficient for the variable interacting income with the marine reserve program is not significant, suggesting no significant income 
effects exist for either of the alternatives with marine reserves. This may because cost of the marine reserve program was generally the least-cost alternative and presented a smaller financial burden on households. The coefficient for the variable interacting gender with coral is negative and significant implying that the presence of coral in the alternative reduced the probability that females would select that alternative. The WRR and UWR variables interacted with coral and marine reserve are positive and significant $(p<.001)$ implying that respondent risk characteristics are positively correlated to WTP for both interventions.

Finally, a weighted risk-adjusted WTP was estimated (Table 28) using the sample average percent of respondents that expressed different levels of agreement to risk attitudes as weights. On average, $5.73 \%$ strongly disagreed (Likert scale $=1$ ), $10.78 \%$ somewhat agreed (2), 28.54\% neutral (3), 27.90\% agreed (4), and 27.05\% strongly agreed (5) to the 14 risk questions. Risk adjusted WTP for coral is approximately $15 \%$ less (\$155) than unadjusted WTP, and risk adjusted WTP for the marine reserve and both alternatives are 129\% (\$22.05) and 37\% higher (\$377), respectively. 
Table 19. Definition of variables included in the rank ordered logit model

\begin{tabular}{|c|c|}
\hline Alternative-specific variables & Variable definition \\
\hline Coral & $\begin{array}{l}\text { A variable indicating the restocking program } \\
\text { appeared in the chosen alternative }\end{array}$ \\
\hline Marine Reserve & $\begin{array}{l}\text { A variable indicating the marine reserve program } \\
\text { appeared in the chosen alternative }\end{array}$ \\
\hline Cost & The cost to the household of the alternative \\
\hline \multicolumn{2}{|c|}{ Individual-specific variables interacted with the restocking program } \\
\hline Times $\mathrm{x}$ coral & $\begin{array}{l}\text { Number of times respondent has visited a coral } \\
\text { reef interacted with alternatives that include the } \\
\text { restocking program. } 0 \text { otherwise }\end{array}$ \\
\hline Age $\mathrm{x}$ coral & $\begin{array}{l}\text { Respondent age interacted with alternatives that } \\
\text { include the restocking program, } 0 \text { otherwise }\end{array}$ \\
\hline Gender x coral & $\begin{array}{l}\text { Gender interacted with alternatives that include the } \\
\text { restocking program, } 0 \text { otherwise }\end{array}$ \\
\hline Flres $\mathrm{x}$ coral & $\begin{array}{l}\text { A dummy variable that equals } 1 \text { if the respondents } \\
\text { is a resident of Florida, interacted with alternatives } \\
\text { that include the restocking program, } 0 \text { otherwise }\end{array}$ \\
\hline WRR $x$ coral & $\begin{array}{l}\text { Risk Factor Score } 1 \text { interacted with alternatives } \\
\text { that include the restocking program, } 0 \text { otherwise }\end{array}$ \\
\hline UWR x coral & $\begin{array}{l}\text { Risk Factor Score } 2 \text { interacted with alternatives } \\
\text { that include the restocking program, } 0 \text { otherwise }\end{array}$ \\
\hline Enviro $\mathrm{x}$ coral & $\begin{array}{l}\text { A dummy variable that equals } 1 \text { if the respondent } \\
\text { indicated they were either a "very strong" or } \\
\text { "strong" environmentalist interacted with } \\
\text { alternatives that include the restocking program. }\end{array}$ \\
\hline Dist $\mathrm{x}$ coral & $\begin{array}{l}\text { Geographic distance from the location where the } \\
\text { survey was completed to the middle of the Florida } \\
\text { Keys interacted with alternatives that include the } \\
\text { restocking program. }\end{array}$ \\
\hline \multicolumn{2}{|c|}{ Individual specific variables interacted with the marine reserve program } \\
\hline Times $\mathrm{x}$ marine reserve & $\begin{array}{l}\text { Whether a respondent has visited a coral reef } \\
\text { interacted with alternatives that include the marine } \\
\text { reserve, } 0 \text { otherwise }\end{array}$ \\
\hline Age $\mathrm{x}$ marine reserve & $\begin{array}{l}\text { Respondent age interacted with alternatives that } \\
\text { include the marine reserve program, } 0 \text { otherwise }\end{array}$ \\
\hline Gender $\mathrm{x}$ marine reserve & $\begin{array}{l}\text { Gender interacted with alternatives that include the } \\
\text { marine reserve program, } 0 \text { otherwise }\end{array}$ \\
\hline Flres $\mathrm{x}$ marine reserve & $\begin{array}{l}\text { A dummy variable that equals } 1 \text { if the respondents } \\
\text { is a resident of Florida, interacted with alternatives } \\
\text { that include the marine reserve program, } 0\end{array}$ \\
\hline WRR $x$ marine reserve & $\begin{array}{l}\text { Risk Factor Score } 1 \text { interacted with alternatives } \\
\text { that include the marine reserve program, } 0\end{array}$ \\
\hline UWR x marine reserve & $\begin{array}{l}\text { Risk Factor Score } 2 \text { interacted with alternatives } \\
\text { that include the marine reserve program, } 0\end{array}$ \\
\hline Enviro $\mathrm{x}$ marine reserve & $\begin{array}{l}\text { A dummy variable that equals } 1 \text { if the respondent } \\
\text { indicated they were either a "very strong" or }\end{array}$ \\
\hline Dist $\mathrm{x}$ marine reserve & $\begin{array}{l}\text { Geographic distance from the location where the } \\
\text { survey was completed to the middle of the Florida } \\
\text { Keys interacted with alternatives that include the } \\
\text { marine reserve program. }\end{array}$ \\
\hline
\end{tabular}


Table 20. Rank ordered logit respondent demographics

\begin{tabular}{lcccccc}
\hline & $n$ & Mean & Med & Std. Dev. & Min & Max \\
\hline Age & 530 & 35.79 & 33 & 13.72 & 16 & 85 \\
Household size & 530 & 2.91 & 3 & 1.288 & 1 & 5 \\
Per capita income (\$000's) & 530 & 25.41 & 17.5 & 24.76 & 10.0 & 250.0 \\
Gender & $n$ & $\%$ & & & & \\
$\quad$ Female & 398 & 75.10 & & & & \\
$\quad$ Male & 132 & 24.90 & & & & \\
Race/Ethnicity & $n$ & $\%$ & & & & \\
$\quad$ White & 362 & 68.3 & & & & \\
$\quad$ Hispanic & 52 & 9.81 & & & & \\
$\quad$ Black or African-American & 95 & 17.92 & & & & \\
$\quad$ Other & 21 & 3.96 & & & & \\
Education & & & & & & \\
$\quad$ Less than high school & 16 & 3.02 & & & & \\
$\quad$ High school graduate & 126 & 23.77 & & & & \\
$\quad$ Some college & 180 & 33.96 & & & & \\
$\quad$ College graduate & 208 & 39.25 & & & & \\
\hline
\end{tabular}

Table 21. Summary of variables included in rank ordered logit model $(n=530)$

\begin{tabular}{lllll}
\hline Variable & Mean & Std. Dev. & Min. & Max. \\
\hline Income & 25.414 & 24.761 & 2 & 250 \\
Times & 1.6111 & 3.4709 & 0 & 30 \\
Age & 35.797 & 13.730 & 16 & 85 \\
Gender & 1.7509 & 0.4326 & 1 & 2 \\
FLres & 0.6528 & 0.4762 & 0 & 1 \\
WRR & 0.0000 & 0.9703 & -3.1130 & 1.4328 \\
UWR & 0.0000 & 0.8036 & -2.2427 & 2.2690 \\
Enviro & 0.26037 & 0.4389 & 0 & 1 \\
\hline
\end{tabular}


Table 22. Risk perception, risk concern, and attitudes toward risk reduction

\begin{tabular}{lccc}
\hline Perception of Risks & $\boldsymbol{n}$ & Mean & Std. Dev. \\
\hline $\begin{array}{l}\text { (1) Florida's coral reefs have deteriorated dramatically in } \\
\text { recent decades. }\end{array}$ & 530 & 3.93 & 1.08 \\
$\begin{array}{l}\text { (2) I am comfortable with the level of risks facing Florida's } \\
\text { coral reefs and marine resources. }\end{array}$ & 530 & 3.71 & 1.17 \\
$\begin{array}{l}\text { (3) The health of Florida's coral reefs is managed by the } \\
\text { relevant authorities. }\end{array}$ & 530 & 2.97 & .94 \\
$\begin{array}{l}\text { (4) The risks to Florida's coral reefs and fisheries will } \\
\text { continue to increase into the future. }\end{array}$ & 530 & 3.81 & 1.03 \\
$\begin{array}{l}\text { (5) Future generations will address the risks faced by } \\
\text { Florida's reefs appropriately }\end{array}$ & 530 & 2.67 & 1.08
\end{tabular}

\begin{tabular}{|c|c|c|c|}
\hline Concern about specific risks & n & Mean & Std. Dev. \\
\hline (6) Regarding the health of Florida's coral reefs & 530 & 3.55 & 1.09 \\
\hline $\begin{array}{l}\text { (7) Regarding overfishing in Florida and other US } \\
\text { states/jurisdictions }\end{array}$ & 530 & 3.53 & 1.12 \\
\hline $\begin{array}{l}\text { (8) Regarding marine pollution and loss of marine } \\
\text { biodiversity }\end{array}$ & 530 & 3.78 & 1.10 \\
\hline $\begin{array}{l}\text { (9) Regarding rising ocean temperatures and bleaching of } \\
\text { Florida's corals }\end{array}$ & 530 & 3.69 & 1.14 \\
\hline $\begin{array}{l}\text { (10) Regarding physical damage to coral reefs and sea grass } \\
\text { beds. }\end{array}$ & 530 & 3.72 & 1.09 \\
\hline Risk reduction or regulation & $n$ & Mean & Std. Dev. \\
\hline $\begin{array}{l}\text { (11) Government agencies must start to take actions to } \\
\text { preserve and protect Florida's coral reef ecosystems. }\end{array}$ & 530 & 4.05 & 1.08 \\
\hline $\begin{array}{l}\text { (12) As a citizen, I am also responsible for contributing } \\
\text { towards the protection and the enhancement of coral reefs. }\end{array}$ & 530 & 3.90 & 1.02 \\
\hline $\begin{array}{l}\text { (13) Any human activities that adversely affect the health of } \\
\text { coral reefs and fish populations should be regulated. }\end{array}$ & 530 & 3.99 & 1.07 \\
\hline $\begin{array}{l}\text { (14) The relevant public agencies will manage Florida's } \\
\text { coral reefs without my contribution to the effort. }\end{array}$ & 530 & 3.08 & 1.20 \\
\hline
\end{tabular}


Table 23. Risk perception, concern, and reduction preferences across demographic groups

\begin{tabular}{|c|c|c|c|c|c|}
\hline $\begin{array}{l}\text { Demographic } \\
\text { Characteristics }\end{array}$ & Levels & $n$ & $\begin{array}{l}\text { RP (Out of } \\
\text { a max score } \\
\text { of } 25)\end{array}$ & $\begin{array}{l}\mathrm{RC} \text { (Out } \\
\text { of a max } \\
\text { score of } \\
25)\end{array}$ & $\begin{array}{l}\text { RR (Out } \\
\text { of a max } \\
\text { score of } \\
20 \text { ) }\end{array}$ \\
\hline \multirow[t]{2}{*}{ Florida } & Yes & 346 & 17.17 & 18.48 & 15.14 \\
\hline & No & 184 & 16.91 & 17.86 & 14.80 \\
\hline$F$ & & & 0.96 & 1.91 & 1.39 \\
\hline$P$ & & & 0.327 & 0.168 & 0.239 \\
\hline \multirow[t]{2}{*}{ Gender } & Male & 132 & 16.7 & 17.8 & 14.6 \\
\hline & Female & 398 & 17.2 & 18.4 & 15.1 \\
\hline$F$ & & & 2.90 & 1.85 & 2.74 \\
\hline$P$ & & & 0.089 & 0.174 & 0.098 \\
\hline \multirow[t]{4}{*}{ Education } & Less than high & 16 & 16.13 & 18.38 & 14.56 \\
\hline & High school & 126 & 16.35 & 16.98 & 14.18 \\
\hline & Some college & 180 & 17.39 & 18.25 & 15.08 \\
\hline & College graduate & 208 & 17.33 & 19.05 & 15.51 \\
\hline$F$ & & & 4.62 & 4.85 & 5.10 \\
\hline$P$ & & & 0.0034 & 0.0024 & 0.0017 \\
\hline \multicolumn{6}{|l|}{ Income2 } \\
\hline$F$ & & & 1.23 & 1.18 & 1.61 \\
\hline$P$ & & & 0.1507 & 0.2021 & 0.0097 \\
\hline \multicolumn{6}{|l|}{ Times2 } \\
\hline$F$ & & & 1.60 & 1.63 & 1.26 \\
\hline$P$ & & & 0.0593 & 0.0524 & 0.2127 \\
\hline \multirow[t]{4}{*}{ Race } & Black & 95 & 16.21 & 17.60 & 14.23 \\
\hline & White & 362 & 17.42 & 18.36 & 15.24 \\
\hline & Hispanic & 52 & 16.62 & 18.90 & 14.96 \\
\hline & Other & 21 & 16.38 & 18.00 & 15.00 \\
\hline$F$ & & & 5.56 & 0.96 & 2.70 \\
\hline$P$ & & & 0.0009 & 0.4118 & 0.0450 \\
\hline
\end{tabular}

${ }^{1}$ In this table, the original respondents' scores of statements \# 2, 3, 5, and 14 of Table 22 are reversed on the scale of 1 to 5 before being grouped with other statements in the respective category and the average value for the group is computed. ${ }^{2}$ For brevity, only $F$ statistic values are reported. 
Table 24. Results of explanatory factor analysis

\begin{tabular}{|c|c|c|}
\hline Variable & $\begin{array}{l}\text { Factor } 1 \\
\text { WRR }\end{array}$ & $\begin{array}{l}\text { Factor } 2 \\
\text { UWR }\end{array}$ \\
\hline Florida's coral reefs have deteriorated dramatically in recent decades. & 0.8064 & -0.0972 \\
\hline $\begin{array}{l}\text { I am comfortable with the level of risks facing Florida's coral reefs and } \\
\text { marine resources. }\end{array}$ & 0.8068 & -0.0298 \\
\hline $\begin{array}{l}\text { The health of Florida's coral reefs is managed by the relevant } \\
\text { authorities. }\end{array}$ & .08388 & 0.0691 \\
\hline $\begin{array}{l}\text { The risks to Florida's coral reefs and fisheries will continue to increase } \\
\text { into the future. }\end{array}$ & 0.8128 & 0.0240 \\
\hline $\begin{array}{l}\text { Future generations will address the risks faced by Florida's reefs } \\
\text { appropriately }\end{array}$ & 0.7959 & 0.0576 \\
\hline Concern regarding the health of Florida's coral reefs & 0.6741 & -0.0704 \\
\hline $\begin{array}{l}\text { Concern regarding overfishing in Florida and other US } \\
\text { states/jurisdictions }\end{array}$ & 0.2422 & 0.6044 \\
\hline Concern regarding marine pollution and loss of marine biodiversity & -0.1141 & 0.6065 \\
\hline $\begin{array}{l}\text { Concern regarding rising ocean temperatures and bleaching of Florida's } \\
\text { corals }\end{array}$ & 0.5811 & -0.0657 \\
\hline Concern regarding physical damage to coral reefs and sea grass beds. & -0.2428 & 0.5022 \\
\hline $\begin{array}{l}\text { Government agencies must start to take actions to preserve and protect } \\
\text { Florida's coral reef ecosystems. }\end{array}$ & 0.7617 & -0.0222 \\
\hline $\begin{array}{l}\text { As a citizen, I am also responsible for contributing towards the } \\
\text { protection and the enhancement of coral reefs. }\end{array}$ & 0.7496 & 0.0367 \\
\hline $\begin{array}{l}\text { Any human activities that adversely affect the health of coral reefs and } \\
\text { fish populations should be regulated. }\end{array}$ & 0.7387 & -0.0213 \\
\hline $\begin{array}{l}\text { The relevant public agencies will manage Florida's coral reefs without } \\
\text { my contribution to the effort. }\end{array}$ & 0.0698 & 0.5068 \\
\hline
\end{tabular}

Loading on a given factor was assumed if loading $>0.50$ ( 
Table 25. Program cost combinations presented in survey

\begin{tabular}{|c|c|c|c|c|c|}
\hline 1 & $\begin{array}{l}\text { Status quo } \\
\text { Restocking } \\
\text { Marine reserves } \\
\text { Combined }\end{array}$ & $\begin{array}{l}0 \\
50 \\
40 \\
85\end{array}$ & 9 & $\begin{array}{l}\text { Status quo } \\
\text { Restocking } \\
\text { Marine reserves } \\
\text { Combined }\end{array}$ & $\begin{array}{l}0 \\
50 \\
160 \\
200\end{array}$ \\
\hline 2 & $\begin{array}{l}\text { Status quo } \\
\text { Restocking } \\
\text { Marine reserves } \\
\text { Combined }\end{array}$ & $\begin{array}{l}0 \\
50 \\
80 \\
125\end{array}$ & 10 & $\begin{array}{l}\text { Status quo } \\
\text { Restocking } \\
\text { Marine reserves } \\
\text { Combined }\end{array}$ & $\begin{array}{l}0 \\
200 \\
40 \\
230\end{array}$ \\
\hline 3 & $\begin{array}{l}\text { Status quo } \\
\text { Restocking } \\
\text { Marine reserves } \\
\text { Combined }\end{array}$ & $\begin{array}{l}0 \\
110 \\
40 \\
140\end{array}$ & 11 & $\begin{array}{l}\text { Status quo } \\
\text { Restocking } \\
\text { Marine reserves } \\
\text { Combined }\end{array}$ & $\begin{array}{l}0 \\
110 \\
160 \\
255\end{array}$ \\
\hline 4 & $\begin{array}{l}\text { Status quo } \\
\text { Restocking } \\
\text { Marine reserves } \\
\text { Combined } \\
\end{array}$ & $\begin{array}{l}0 \\
110 \\
80 \\
180 \\
\end{array}$ & 12 & $\begin{array}{l}\text { Status quo } \\
\text { Restocking } \\
\text { Marine reserves } \\
\text { Combined } \\
\end{array}$ & $\begin{array}{l}0 \\
140 \\
120 \\
245 \\
\end{array}$ \\
\hline 5 & $\begin{array}{l}\text { Status quo } \\
\text { Restocking } \\
\text { Marine reserves } \\
\text { Combined } \\
\end{array}$ & $\begin{array}{l}0 \\
50 \\
120 \\
160 \\
\end{array}$ & 13 & $\begin{array}{l}\text { Status quo } \\
\text { Restocking } \\
\text { Marine reserves } \\
\text { Combined } \\
\end{array}$ & $\begin{array}{l}0 \\
200 \\
80 \\
265 \\
\end{array}$ \\
\hline 6 & $\begin{array}{l}\text { Status quo } \\
\text { Restocking } \\
\text { Marine reserves } \\
\text { Combined }\end{array}$ & $\begin{array}{l}0 \\
140 \\
40 \\
170 \\
\end{array}$ & 14 & $\begin{array}{l}\text { Status quo } \\
\text { Restocking } \\
\text { Marine reserves } \\
\text { Combined }\end{array}$ & $\begin{array}{l}0 \\
140 \\
160 \\
285 \\
\end{array}$ \\
\hline 7 & $\begin{array}{l}\text { Status quo } \\
\text { Restocking } \\
\text { Marine reserves } \\
\text { Combined } \\
\end{array}$ & $\begin{array}{l}0 \\
140 \\
80 \\
210 \\
\end{array}$ & 15 & $\begin{array}{l}\text { Status quo } \\
\text { Restocking } \\
\text { Marine reserves } \\
\text { Combined } \\
\end{array}$ & $\begin{array}{l}0 \\
200 \\
120 \\
305 \\
\end{array}$ \\
\hline 8 & $\begin{array}{l}\text { Status quo } \\
\text { Restocking } \\
\text { Marine reserves } \\
\text { Combined } \\
\end{array}$ & $\begin{array}{l}0 \\
110 \\
120 \\
220\end{array}$ & 16 & $\begin{array}{l}\text { Status quo } \\
\text { Restocking } \\
\text { Marine reserves } \\
\text { Combined }\end{array}$ & $\begin{array}{l}0 \\
200 \\
160 \\
340 \\
\end{array}$ \\
\hline
\end{tabular}

*Due to human error, cost combination six was not presented to respondents of the choice model questions presented in dichotomous choice format. 
Table 26. Results of rank ordered logit

\begin{tabular}{|c|c|c|c|c|c|c|c|}
\hline & Model 1 & Model 2 & Model 3 & Model 4 & Model 5 & Model 6 & Model 7 \\
\hline \multirow[t]{2}{*}{ Bid } & $-0.0019^{* *}$ & $-0.0019^{* *}$ & $-0.0019^{* *}$ & $-0.0019^{* *}$ & $-0.0019^{* *}$ & $-0.0018^{* *}$ & $-0.0019^{* *}$ \\
\hline & $(0.0008)$ & $(0.0008)$ & $(0.0008)$ & $(0.0008)$ & $(0.0008)$ & $(0.0008)$ & $(0.0008)$ \\
\hline \multirow[t]{2}{*}{ Coral } & 0.3316 & 0.2446 & 0.2663 & 0.2581 & 0.3456 & $0.5487^{* *}$ & 0.2179 \\
\hline & $(0.4008)$ & $(0.3890)$ & $(0.3880)$ & $(0.3654)$ & $(0.3511)$ & $(0.2838)$ & $(0.2724)$ \\
\hline \multirow[t]{2}{*}{ Marine reserve } & -0.1068 & -0.1626 & -0.1387 & -0.0758 & -0.0935 & 0.1908 & -0.0140 \\
\hline & $(0.3757)$ & $(0.3644)$ & $(0.3639)$ & $(0.3403)$ & $(0.3261)$ & $(0.2629)$ & $(0.2526)$ \\
\hline \multirow[t]{2}{*}{ Edu * coral } & 0.0676 & 0.0690 & 0.0728 & 0.0764 & 0.0721 & & \\
\hline & $(0.0738)$ & $(0.0736)$ & $(0.0733)$ & $(0.0726)$ & $(0.0725)$ & & \\
\hline \multirow[t]{2}{*}{$\mathrm{Edu} * \mathrm{MR}$} & 0.0959 & 0.0957 & 0.1026 & 0.0984 & 0.1006 & & \\
\hline & $(0.0696)$ & $(0.0693)$ & $(0.0691)$ & $(0.0684)$ & $(0.0683)$ & & \\
\hline \multirow[t]{2}{*}{ Inc $*$ coral } & 0.0043 & 0.0043 & $0.0045^{*}$ & $0.0044^{*}$ & $0.0046^{*}$ & $0.0052^{* *}$ & $0.0058^{* *}$ \\
\hline & $(0.0027)$ & $(0.0027)$ & $(0.0027)$ & $(0.0027)$ & $(0.0027)$ & $(0.0026)$ & $(0.0025)$ \\
\hline \multirow[t]{2}{*}{ Inc $*$ MR } & -0.0011 & -0.0011 & -0.0008 & -0.0005 & -0.0006 & 0.0005 & 0.00031 \\
\hline & $(0.0025)$ & $(0.0025)$ & $(0.0025)$ & $(0.0025)$ & $(0.0025)$ & $(0.0024)$ & $(0.0023)$ \\
\hline \multirow[t]{2}{*}{ Times $*$ coral } & 0.0138 & 0.0129 & & & & & \\
\hline & $(0.0182)$ & $(0.0182)$ & & & & & \\
\hline \multirow[t]{2}{*}{ Times * MR } & 0.0219 & 0.0215 & & & & & \\
\hline & $(0.0175)$ & $(0.0174)$ & & & & & \\
\hline \multirow[t]{2}{*}{ Age $*$ coral } & 0.0008 & 0.0005 & 0.0003 & & & & \\
\hline & $(0.0044)$ & $(0.0044)$ & $(0.0044)$ & & & & \\
\hline \multirow[t]{2}{*}{ Age $* M R$} & 0.0014 & 0.0012 & 0.0009 & & & & \\
\hline & $(0.0042)$ & $(0.0042)$ & $(0.0042)$ & & & & \\
\hline \multirow[t]{2}{*}{ Gender $*$ coral } & $-0.3704^{* * *}$ & $-0.3721^{* * *}$ & $-0.3803^{* * *}$ & - & - & - & $-0.2332^{*}$ \\
\hline & $(0.1399)$ & $(0.1392)$ & $(0.1386)$ & $(0.1381)$ & $(0.1379)$ & $(0.1379)$ & $(0.1323)$ \\
\hline \multirow[t]{2}{*}{ Gender * MR } & -0.0189 & -0.0168 & -0.0283 & -0.0402 & -0.0413 & -0.0413 & 0.0520 \\
\hline & $(0.1317)$ & $(0.1311)$ & $(0.1308)$ & $(0.1304)$ & $(0.1301)$ & $(0.1301)$ & $(0.1259)$ \\
\hline \multirow[t]{2}{*}{ Flres $*$ coral } & 0.0725 & 0.0985 & 0.1074 & 0.1075 & & & \\
\hline & $(0.1272)$ & $(0.1245)$ & $(0.1238)$ & $(0.1236)$ & & & \\
\hline \multirow[t]{2}{*}{ Flres * MR } & -0.0621 & -0.0437 & -0.0277 & -0.0242 & & & \\
\hline & $(0.1209)$ & $(0.1185)$ & $(0.1178)$ & $(0.1176)$ & & & \\
\hline \multirow[t]{2}{*}{ WRR * coral } & $0.5935^{* * *}$ & $0.5935^{* * *}$ & $0.5959^{* * * *}$ & $0.5949^{* * *}$ & $0.5968^{* * *}$ & $0.6037^{* * *}$ & \\
\hline & $(0.0701)$ & $(0.0695)$ & $(0.0695)$ & $(0.0690)$ & $(0.0690)$ & $(0.0683)$ & \\
\hline \multirow[t]{2}{*}{$\mathrm{WRR} * \mathrm{MR}$} & $0.4298^{* * *}$ & $0.4214^{* * *}$ & $0.4259^{* * * *}$ & $0.4304^{* * *}$ & $0.4297^{* * * *}$ & $0.4412^{* * *}$ & \\
\hline & $(0.0652)$ & $(0.0645)$ & $(0.0644)$ & $(0.0639)$ & $(0.0639)$ & $(0.0632)$ & \\
\hline \multirow[t]{2}{*}{ UWR * coral } & $0.2223^{* * *}$ & $0.2204^{* * *}$ & $0.2120^{* * * *}$ & $0.2096^{* * *}$ & $0.2109^{* * *}$ & $0.2108^{* * *}$ & \\
\hline & $(0.0771)$ & $(0.0763)$ & $(0.0754)$ & $(0.0748)$ & $(0.0747)$ & $(0.0746)$ & \\
\hline \multirow[t]{2}{*}{ UWR * MR } & $0.2312^{* * *}$ & $0.2373^{* * *}$ & $0.2256^{* * * *}$ & $0.2354^{* * *}$ & $0.2338^{* * * *}$ & $0.2366^{* * *}$ & \\
\hline & $(0.0731)$ & $(0.0724)$ & $(0.0717)$ & $(0.0711)$ & $(0.0711)$ & $(0.0710)$ & \\
\hline \multirow[t]{2}{*}{ Enviro $*$ coral } & $0.3419^{* *}$ & $0.3575^{* *}$ & $0.3680^{* *}$ & $0.3706^{* * *}$ & $0.3745^{\text {*** }}$ & $0.3688^{* * *}$ & $0.7374^{* * *}$ \\
\hline & $(0.1473)$ & $(0.1463)$ & $(0.1454)$ & $(0.1441)$ & $(0.1440)$ & $(0.1434)$ & $(0.1326)$ \\
\hline Enviro * MR & 0.1355 & 0.1473 & 0.1643 & 0.1542 & 0.1545 & 0.1389 & $0.4181^{* * *}$ \\
\hline & $(0.1402)$ & $(0.1388)$ & $(0.1380)$ & $(0.1371)$ & $(0.1371)$ & $(0.1362)$ & $(0.1266)$ \\
\hline Dist $*$ coral & -0.0001 & & & & & & \\
\hline & $(0.0001)$ & & & & & & \\
\hline Dist * MR & -0.0001 & & & & & & \\
\hline & $(0.0001)$ & & & & & & \\
\hline Observations & 527 & 529 & 529 & 530 & 530 & 530 & 530 \\
\hline LR chi $^{2}$ & 222.93 & 224.47 & 222.46 & 223.41 & 222.61 & 211.60 & 67.95 \\
\hline Log-likelihood & -1563.371 & -1568.955 & -1569.961 & - & - & - & - \\
\hline
\end{tabular}

Standard errors in parentheses; $* \mathrm{p}<0.10, * * \mathrm{p}<0.05, * * * \mathrm{p}<0.01$ 
Table 27. Annual HH WTP estimates

\begin{tabular}{cccccccc}
\hline Program & Model 1 & $\begin{array}{c}\text { Model 2 } \\
\text { Remove } \\
\text { dist. }\end{array}$ & $\begin{array}{c}\text { Model 3 } \\
\text { Remove } \\
\text { times }\end{array}$ & $\begin{array}{c}\text { Model 4 } \\
\text { Remove } \\
\text { age }\end{array}$ & $\begin{array}{c}\text { Model 5 } \\
\text { Remove } \\
\text { flres }\end{array}$ & $\begin{array}{c}\text { Model 6 } \\
\text { Remove } \\
\text { edu }\end{array}$ & $\begin{array}{c}\text { Model 7 } \\
\text { Remove } \\
\text { risk1, 2 }\end{array}$ \\
\hline Coral & 119.11 & 95.97 & 100.76 & 98.25 & 141.05 & 179.01 & 94.72 \\
Marine Reserves & 14.81 & .03 & 7.35 & 24.54 & 20.16 & 96.60 & 46.25 \\
Both & 133.92 & 96.00 & 108.11 & 122.79 & 120.89 & 275.61 & 140.82 \\
\hline
\end{tabular}

Table 28. Marginal WTP results at various levels of risk perception

\begin{tabular}{|l|c|c|c|c|c|c|c|}
\hline & \multicolumn{6}{|c|}{ Attributes-Interacted with Risk Perception Model } \\
\hline $\begin{array}{l}\text { Risk } \\
\text { Perception }\end{array}$ & $\begin{array}{l}\text { Risk }=3.60 \\
\text { Coral }\end{array}$ & $1^{\mathrm{a}}$ & $2^{\mathrm{a}}$ & 3 & 4 & 5 & $\begin{array}{c}\text { Risk- } \\
\text { weighted } \\
\text { average } \\
\text { WTP }\end{array}$ \\
\hline MR & $\$ 179.01$ & $\$ 0.00$ & $\$ 0.00$ & $\$ 27.40$ & $\$ 270.35$ & $\$ 513.33$ & $\$ 155.27$ \\
\hline Both & $\$ 275.61$ & $\$ 0.00$ & $\$ 0.00$ & $\$ 27.40$ & $\$ 454.07$ & $\$ 897.90$ & $\$ 377.30$ \\
\hline
\end{tabular}

${ }^{a}$ Computed WTP values were negative for risk perception levels of Likert scale 1, 2, and 3 (MR only). Since negative WTP values (disutility from improved attributes) seem unrealistic, those values were discarded and WTP values were assumed to be zero at risk perception levels of 1,2, and 3 (MR only).

${ }^{b}$ Risk-weighted average WTP values are computed by using average percent of respondents expressing different levels ( 1 to 5) of agreement to all risk questions as weights. On an average, 5.73\% strongly disagreed (Likert scale $=1$ ), $10.78 \%$ somewhat disagreed (2), 28.54\% neutral (3), 27.90\% agreed (4), and $27.04 \%$ strongly agreed (5) to the fourteen risk questions.

Table 29. Aggregated WTP for restocking and combined programs

\begin{tabular}{llllll}
\hline Program & $\begin{array}{l}\text { Certified } \\
\text { Florida divers }\end{array}$ & $\begin{array}{l}\text { South FL } \\
\text { HH }\end{array}$ & Florida HH & SE US HH & $\begin{array}{l}\text { South FL } \\
\text { coral users }\end{array}$ \\
\hline Restocking & $2,247,091$ & $22,550,093$ & $65,165,430$ & $124,695,951$ & $10,551,742$ \\
Combined & $5,845,497$ & $58,660,947$ & $169,518,852$ & $324,379,268$ & $27,448,896$ \\
\hline *5 hectares; 2017 dollars & & & &
\end{tabular}




\subsection{Discussion and management implications}

\subsection{Nonmarket benefits from restocking and protecting staghorn corals}

Staghorn corals are critical to the diversity and productivity of the FRT, supporting local and regional fisheries, tourism, recreation, and educational and spiritual experiences (Wilkinson, 2008; Principe et al., 2012). Staghorn coral was among most abundant and ecologically dominant corals on shallow Caribbean reefs for the last one million years until the 1970s and 1980s (Goreau 1959; Geister 1977; Adey 1978; Jackson 1992, 1994; Pandolfi 2002; Pandolfi and Jackson, 2001, 2006). Today staghorn corals in the Florida Keys occur primarily in patch reefs as opposed to their former abundance in deeper forereef habitats and, under current conditions, are believed to face localized extirpation in the next 100 years without active intervention (Miller et al., 2008); declines in abundance have been estimated at $97 \%$ in some locations. Active restoration to mitigate losses in coral cover is increasingly becoming considered a critical component of coral conservation and recovery efforts (Precht, 2006; Edwards and Gomez, 2007; Lirman and Schopmeyer, 2016; Schopmeyer, et al., 2017); Currently, tens of thousands of staghorn coral colonies are being transplanted annually onto Florida reefs. Nursery reared outplants are reaching sexual maturity within two years of outplanting and have been observed spawning, showing outplants can contribute to the species. Linking active restoration with other available management tools such as marine reserves is widely believed among practitioners to offer the highest likelihood of success to reef restoration efforts in areas impacted by human activities (Young et al., 2012). Changes in coral reef ecosystems and reef health will alter the life cycle of reef dependent fish species (Syms 
and Jones, 2000) and thus fisheries productivity, biodiversity, and economic value of the FRT.

\subsection{Implications for coastal resource management}

This study provides coastal resource managers with insight into the economic benefits of enhanced staghorn coral populations and overall coral reef ecosystem health on the FRT and addresses some of the recurring challenges of ecosystem restoration and management, including uncertainty regarding the existence and severity of risks and the need for intervention, ecological and economic benefits estimation from ecosystem restoration, and the appropriate distribution of costs in relation to the extent of benefits. Results of this study suggest the public believes the risks to Florida's coral reefs and fisheries will continue to increase in the future and that it is incumbent upon government agencies to take actions to preserve and protect Florida's coral reef ecosystems. Results also indicate the public is uncertain as to whether the relevant public agencies will manage Florida's coral reefs without their contribution and feels a responsibility to contribute to the protection and the enhancement of coral reefs, as evidenced by the substantial WTP estimates. The public's moderately high level of concern regarding the risks facing Florida's coral reefs and coastal resources may partially explain why respondents strongly supported the regulation of any human activities that adversely affect the health of coral reefs and fish populations.

As mentioned previously, the results of this study clearly indicate respondent risk characteristics influence their valuation of ecosystem services. Risk-adjusted and non-risk adjusted WTP values were estimated for comparison; At a risk level of five, the highest, WTP values for the marine reserve and both programs are substantially higher than non- 
risk-adjusted WTP values and WTP estimates for the three management alternatives from model 7 , which contains no risk variables, average $97.86 \%$ lower than those from model 6, containing the risk variables; Inclusion of the two risk variables in the model approximately doubles WTP for each of the three alternatives confirming the magnitude of the influence of risk characteristics on WTP.

Valuation results are comparable with those of similar studies examining the public's values for coral reef and coastal ecosystem health suggesting broad support among the national population for the protection of coastal resources. Using a stated preference survey approaches Stefanski and Shimshack (2015) found WTP to expand marine protected areas in the northern Gulf of Mexico ranged from $\$ 35$ - \$107 per household and Bishop, et al. (2011) estimated mean WTP to implement marine reserves to protect $25 \%$ of the Hawaiian island's coral reef ecosystems to be $\$ 224.81$, WTP to restore five acres of coral reefs annually to be $\$ 62.82$.

Dichotomous choice and rank-ordered data are commonly fit using several different econometric models. Here, we assume the error terms are distributed extreme values and, accordingly, use conditional and rank ordered logit for the dichotomous choice and rank-ordered data, respectively. With the rank ordered logit, the probability of the respondents' second and third choices (conditional probabilities) in the choice model are the same as the unconditional probabilities, i.e., no statistical information about the respondent is gathered as the rank ordered logit fits the respondent's sequence of rankings (Train, 2002; Bishop, 2011). In practice, this means the choice model would perform just as well as a sequence of three separate choices made by three different respondents (Bishop, 2011). Employing an alternative econometric model like the rank- 
ordered probit, which does not treat respondent rankings as separate choices, may shed more light on the probability of various choice sequences among respondents.

An underlying objective of this study was to improve our understanding of the extent of the market for a large-scale coral restocking program in SE Florida through examination of the empirical relationship between household WTP and distance from the Florida Keys. The extent of the beneficiaries of, and market for, restoration efforts is a critical input in cost-benefit analysis of staghorn recovery efforts and estimation of project's net economic value. Further, knowledge of the extent of the market may help determine the appropriate scale of education and outreach efforts aimed at developing support for staghorn recovery as well as whether project costs should be borne at the county, state, or federal level, for example.

The insensitivity of household WTP to both distance from the Florida Keys and experience with coral reefs in the past three years suggests there may be something novel about the program, coral reefs, or staghorn corals that appeals broadly to coral reef users and non-users. One explanation may be staghorn's designation as threatened under the ESA. In a CV study examining the public's WTP to conserve endangered species, Samples et al., (1986) found that respondents allocated more of their conservation dollars to endangered but recoverable animals as compared with extremely common or extremely rare animals and, through a meta-analysis of 31 studies, Richardson and Loomis (2009) found that the non-market values of species in the US are sensitive to changes in the size of species population, suggesting WTP may be influenced by strategic considerations. Another explanation for the insensitivity of household WTP to distance 
may be that the public attributes value to the FRT's irreplaceability and uniqueness as the third largest barrier reef in the world and only barrier reef in North America.

Our findings of support for efforts to restock and protect staghorn corals among and users and non-users are in harmony with the listing of staghorn coral under the federal ESA and the leadership of NOAA, a federal agency, in implementing a regional restocking plan. Federal leadership suggests the FRT is considered an environmental amenity of national significance by the federal government and that as residents we all derive benefits from its presence and preservation.

Aggregated WTP values extrapolated to various relevant population are presented in Table 29. Relative to terrestrial private property values, the magnitude of several of the aggregated valuation estimates are substantial and may seem implausible. As Bishop et al., (2011) notes, comparison of the benefits from a hectare of terrestrial privately-owned property to the market and non-market benefits flowing from a hectare of coral reef ecosystem, a public good, is tempting but inappropriate according to economic theory, which distinguishes between private and public goods. Many of the benefits of staghorn restocking and protection are non-excludable and non-rival meaning no one can be excluded from the enjoyment of the passive use values generated by restocking and protecting staghorn corals, and one individual's enjoyment of those benefits does not impact others' enjoyment. The economic benefits from protection and restoration can, therefore, be much larger per unit area than would be true for private goods.

However, these extremely large values derived by extrapolating household WTP to state or regional populations may not translate into program support. Because non-use values often make up most of the total economic value of public goods like coral reefs, 
extrapolating to smaller populations, particularly users like scuba divers or tourists, for example, likely provides a more realistic estimation of values. Educating and targeting such user groups for financial and political support for regional conservation programs examined in this study may yield more favorable results.

The models presented here highlight the complexity of the determinants of public preferences and WTP for enhanced ecosystem services supported by staghorn corals. Socio-demographic and economic variables like age, education, and income were statistically insignificant in almost all the valuation models. The risk variables, WRR and UWR, however, were highly significant (at the $1 \%$ level) in every model. These results reveal that general concern about the health of Florida's coral reef ecosystems and perception of risks associated with the loss of staghorn coral populations play a prominent role in shaping consumer preferences for reductions in the risks facing Florida's coastal resources, with respect to the probability of participating in the market and WTP amount. The results of similar studies are mixed. For example, Alberini and Scasny (2010) found that risk characteristics, method for reducing risk, and income, drove most of the heterogeneity in respondent preferences while other individual characteristics (e.g., age and education) were less impactful; Hunter et al., (2012), however, found risk characteristics to be of secondary importance to individual respondent characteristics in influencing market participation and WTP. Nevertheless, the significance and magnitude of the coefficients of the WRR and UWR risk variables in this study suggest education and outreach could enhance support for the regional restocking program. 


\subsection{Conclusion}

Results of this study suggest users and non-users associate substantial non-market benefits with the restoration and protection of staghorn corals and Florida's coral reef ecosystems that are not affected significantly by distance from the Florida Keys, where most of the active restoration in Florida is occurring. These results are relevant and timely for resource managers in SE Florida as staghorn restocking is scaled up regionally and appropriate sources of funding are considered. Also, of relevance for resource managers is the significant influence of risk perception, risk concern, and attitudes toward risk reduction actions on WTP. In the face of climate change and increasing threats to coral reef ecosystems, the public's perception of the condition of Florida's coral reefs, concern for future risk, and sense of personal responsibility will influence the level of political support for the restoration and protection of Florida's coral reef ecosystems. Programs to increase public awareness and literacy regarding the condition, threats, and outlook of Florida's staghorn corals and coral reef ecosystems may engender support and help ensure the persistence of regional staghorn populations.

\section{References}

Acropora Biological Review Team. 2005. Atlantic Acropora Status Review Document. Report to National Marine Fisheries Service, Southeast Regional Office. 152 p.

Alberini, A., Scasny, M., 2010. Context and the VSL: evidence from a stated preference study in Italy and the Czech Republic. Environ Resource Econ. 49, 511-538.

Adamowicz, W., Boxall, P., Williams, M., Louviere, J., 1998. Stated Preference Approaches for Measuring Passive Use Values: Choice Experiments and Contingent Valuation. Am. J. Agric. Econ. 80, 64-75.

Adey, W.H., 1978. Coral Reef Morphogenesis: A Multidimensional Model. Science 202:831-837. 
Adey, W.H., Burke, R. B., 1977. Holocene Bioherms of Lesser Antilles - Geologic Control of Development. In: Frost, S. H., Weiss, M. P., Saunders, J. B. (eds.) Reefs and Related Carbonates. American Association. Petroleum Geologists. Tulsa, Oklahoma, pp. 67-81.

Aldrich, G.A., Grimsrud, K.M., Thacher, J.A., Kotchen, M.J., 2007. Relating Environmental Attitudes and Contingent Values: How Robust are Methods for Identifying Preference Heterogeneity? Environ Resource Econ. 37, 757-75.

Allgeier, J.E., Valdivia, A., Cox, C., Layman, C.A., 2016. Fishing Down Nutrients on Coral Reefs. Nat. Comm. 7: 12461. PMID 27529748 DOI: 10.1038/ncomms 12461.

Arlinghous, R., Mehner, T., 2004. Testing the Reliability and Construct Validity of a Simple and Inexpensive Procedure to Measure the Use Value of Recreational Fishing. Fisheries Management and Ecology. 11:61-64.

Aronson, R.B., Precht, W.F., 2001. White-band Disease and the Changing Face of Caribbean Coral Reefs. Hydrobiologia. 460, 25-38.

Aronson, R.B., Precht, W.F., 2006. Conservation, Precaution, and Caribbean reefs. Coral Reefs. 25, 441-450. doi:10.1007/s00338-006-0122-9.

Aronson, R.B., Precht, W.F., 2001. Evolutionary Paleoecology of Caribbean Coral Reefs. In: Evolutionary Paleoecology: The Ecological Context of Macroevolutionary Change (ed. Allmon, W.D. \& Bottjer, D.J.). Columbia University Press, New York, pp. 171-233.

Arrow, K., Solow R., Portney, P.R., Leamer, E.E., Radner, R., Schuman, H., 1993. Report of the NOAA Panel on Contingent Valuation: Natural Resource Damage Assessment Under the Oil Pollution Act of 1990. Federal Register. 58, 4601-4614.

Bateman, I.J., Langford, I.H., 1997. Non-users Willingness to Pay for a National Park: An Application and Critique of the Contingent Valuation Method. Regional Studies. $31: 6,571-582$.

Bateman, I.J., Brainard, J.S., Lovett, A.A., 1995. Modelling Woodland Recreation Demand Using Geographical Information Systems: A Benefits Transfer Study. Global Environmental Change Working Paper 95-06, Centre for Social and Economic Research on the Global Environment (CSERGE), University College London and University of East Anglia, Norwich.

Berrens, R.P., Bohara, A.K., Jenkins-Smith, H., Silva, C., Weimer, D.L., 2003. The Advent of Internet Surveys for Political Research: A Comparison of Telephone and Internet Samples. Political Analysis. 11:1,1-22.

Berrens, R.P., Bohara, A.K., Jenkins-Smith, H., Silva, C.L., Weimer, D.L., 2004. Information and Effort in Contingent Valuation Surveys: Application to Global Climate 
Change Using National Internet Samples. Journal of Environmental Economics and Management. 47, 331-363.

Bhat, M.G., 2003. Application of Non-Market Valuation to the Florida Keys Marine Reserve Management. Journal of Environmental Management. 67, 315-325.

Birkeland, C., 1997. Life and Death of Coral reefs. Chapman and Hall, New York, p. 536.

Bishop, R., Chapman, D., Kanninen, B., Krosnick, J., Leeworthy, B., Meade, N., 2011. Total Economic Value for Protecting and Restoring Hawaiian Coral Reef Ecosystems: Final Report. Silver Spring, MD: NOAA: Office of National Marine Sanctuaries, Office of Response and Restoration, and Coral Reef Conservation Program. NOAA Technical Memorandum CRCP 16. 406pp.

Bowden-Kerby, A., 2001. Low-tech Coral Reef Restoration Methods Modeled After Natural Fragmentation Processes. Bulletin of Marine Science. 69, 915-931.

Brander, L., van Beukering, P., 2013. The Total Economic Value of U.S. Coral Reefs: A Review of the Literature. NOAA Coral Reef Conservation Program, Silver Spring, MD.

Bruckner, A.W., 2002. Proceedings of the Caribbean Acropora Workshop: Potential Application of the US Endangered Species Act as a Conservation Strategy. NOAA Tech Memo NMFSOPR-24, Silver Spring, MD. 199 p.

Burke, L., Maidens, J., 2004. Reefs at Risk in the Caribbean. Washington, DC.: World Resources Institute. Available from: http://pdf.wri.org/reefs_caribbean_full.pdf. Accessed April 2018.

Burke L.M., Reytar, K., Spalding, M., Perry, A., 2011. Reefs at risk revisited. World Resources Institute, Washington, DC. p.114.

Campbell, K.R., Dickey, R.J., Sexton, R., Burger, J., 2002. Fishing Along the Clinch River Arm of Watts Bar Reservoir Adjacent to the Oak Ridge Reservation, Tennessee: Behavior, Knowledge and Risk Perception. Sci Total Environ. 299,145-61.

Can, O., Alp, E., 2012. Valuation of Environmental Improvements in a Specially Protected Marine Area: A Choice Experiment Approach in Gocek Bay, Turkey. Science of the Total Environment. 439, 291-298.

Carpenter, K.E., R.I. Miclat, V.D. Albaladejo, V.T. Corpuz., 1981. The Influence of Substrate Structure on the Local Abundance and Diversity of Philippine Reef Fishes. Proc. $4^{\text {th }}$ Int'l Coral Reef Symposium. Manila 2, 497-502. 
Carson, R.T., Flores, N.E., Mitchell, R.C. 1999. The Theory and Measurement of Passive Use Value. In: Bateman, I.J., Willis, K.G. (eds.) Valuing Environmental Preferences: Theory and Practice of the Contingent Valuation Method in the USA, EC, and Developing Countries. New York: Oxford University Press, pp. 97-130.

Carson, R.T., Mitchell, R.C., 1993. The Value of Clean Water: The Public's Willingness to Pay for Boatable, Fishable, and Swimmable Quality Water. Water Res Research 29, 2445-2454.

Carson, R.T., Mitchell, R.C., Ruud, P.A., 1990. Valuing Air Quality Improvements: Simulating a Hedonic Equation in the Context of a Contingent Valuation Scenario, in C. V. Mathai, (eds.), Visibility and Fine Particles, 639-946, Pittsburgh: Air \& Waste Management Association.

Carte', B.K., 1996. Biomedical Potential of Marine Natural Products. Bioscience. 46, 271-286.

Concu, G.B., 2007. Investigating Distance Effects on Environmental Values: A Choice Modelling Approach. The Australian Journal of Agricultural and Resource Economics. $51,175-194$.

Cooper P., Poe, G.L., Bateman, I.J., 2004. The Structure of Motivation for Contingent Values: A Case Study of Lake Water Quality Improvement. Ecol. Econ. 50, 69-82. Devlieger, I., Mayer, A. Rosseel, Y., 2016. Hypothesis testing using factor score regression: A comparison of four methods. Educational and Psychological Measurement, 76, 741-770. doi: 10.1177/0013164415607618.

DiStefano, C., Zhu, M., Mindrila, D., 2009. Understanding and Using Factor Scores: Considerations for the Applied Researcher. 14:20.

Done, T.J., Ogden, J.C., Wiebe, W.J., Rosen, B.R., 1996. Biodiversity and Ecosystem Function of Coral Reefs. In: Mooney, H.A., Cushman, J.H., Medina, E., Sala, O.E., Schulze, E.D. (eds.), Functional Roles of Biodiversity: A Global Perspective. SCOPE 1996, John Wiley and Sons.

Edwards, A.J. (ed.), 2010. Reef Rehabilitation Manual. Coral Reef Targeted Research \& Capacity Building for Management Program: St Lucia, Australia. 166 pp

Edwards, A.J., Gomez, E.D., 2007. Reef Restoration Concepts and Guidelines: Making Sensible Management Choices in the Face of Uncertainty. Coral Reef Targeted Research $\&$ Capacity Building for Management Programme, St Lucia, Australia. 38 pp. 
Epstein, N., Bak, R.P.M., Rinkevich, B., 2003. Applying Forest Restoration Principles to Coral Reef Rehabilitation. Aquatic Conservation. 13, 387-395. http://dx.doi.org/10.1002/aqc.558

Epstein, N., Bak, R.P.M, Rinkevich, B., 2001. Strategies for Gardening Denuded Coral Reef Areas: The Applicability of Using Different Types of Coral Material for Reef Restoration. Restoration Ecology. 9, 432-442. http://dx.doi.org/10.1046/j.1526$\underline{\text { 100X.2001.94012.X }}$

Federal Register, 2008. Endangered and Threatened Species; Critical Habitat for Threatened Elkhorn and Staghorn Corals; Final Rule, 73, 229. National Marine Fisheries Service, National Oceanic and Atmospheric Administration.

Federal Register, 2000. Presidential Documents. Executive Order 13158, May 26, 2000. Volume 65, No. 105. May31, 2000. Washington, D.C.

Federal Register, 1998. Presidential Documents. Executive Order 13089, June 11, 1998. Volume 63, No. 115. June 16, 1998. Washington, D.C.

Flynn, J., Slovic, P., Mertz, C.K. 1994. Gender, Race, and Perception of Environmental Health Risks. Risk Analysis. 14:6, 1101-1108.

Finucane, M. L., Alhakami, A., Slovic, P., Johnson, S.M., 2000. The Affect Heuristic in Judgments of Risks and Benefits. Journal of Behavioral Decision Making 13:1, 1-17.

Georgiou, S., Langford, I., Bateman, I., Turner, K., 1998. Determinants of Individuals' Willingness to Pay for Perceived Reductions in Environmental Health Risks: A Case Study of Bathing Water Quality. Environment and Planning. 30, 577-594.

Geister, J., 1977. The Influence of Wave Exposure on the Ecological Zonation of Caribbean Coral Reefs. Proceedings of the 3rd International Coral Reef Symposium, 1, 23-29.

Gladfelter, E.H., 1983. Skeletal Development in Acropora Cervicornis II: Diel Patterns of Calcium Carbonate Accretion. Coral Reefs. 2, 91-100.

Goreau, T.F., 1959. The Physiology of Skeleton Formation in Corals I. A Method for Measuring the Rate of Calcium Deposition by Corals under Different Conditions. The Biological Bulletin

$116,59-75$.

Goreau, T.J., Hilbertz, W., 2005. Marine Ecosystem Restoration: Costs and Benefits for Coral Reefs. World Journal of Research and Review 17, 375-409. 
Goreau, T.J., Hilbertz, W., Hakeem, A.A.A., Sarkisian, T., Gutzeit, F., Spenhoff, A., 2012. Restoring Reefs to Grow Back Beaches and Protect Coasts from Erosion and Global sea level rise. In: Innovative Methods of Marine Ecosystem Restoration. Goreau, T.J. and Trench, R.K. (Ed.). CRC Press. 11-34.

Graham, N.A.J., Wilson, S.K., Jennings, S., Polunin, N.V.C., Bijoux, J.P. \& Robinson, J., 2006. Dynamic Fragility of Oceanic Coral Reef Ecosystems. Proc. Natl Acad. Sci.

U.S.A., 103, 8425-8429.

Grigg, R. W. 1994. Effects of Sewage Discharge, Fishing Pressure and Habitat Complexity on Coral Ecosystems and Reef Fishes in Hawaii. Mar. Ecol. Prog. Ser. 103: 25-34.

Grigg, R.W., Dollar, S.J., 1990. Natural and Anthropogenic Disturbance on Coral Reefs. In: Dubinsky, Z. (Ed.), Ecosystem of the world 25. Elsevier, New York, pp. 439-452.

Guannel, G., Arkema, K., Ruggiero, P., Verutes, G., 2016. The Power of Three: Coral Reefs, Seagrasses and Mangroves Protect Coastal Regions and Increase Their Resilience. PLoS ONE 11(7): e0158094. https://doi.org/10.1371/journal.pone.0158094.

Guzmán, H.M., 1991. Restoration of Coral Reefs in Pacific Costa Rica. Conservation Biology, 5, 189-195. http://dx.doi.org/10.1111/j.1523-1739.1991.tb00123.x

Hanley, N., Colombo, S., Tinch, D., Black, A., Aftab, A., 2006. Estimating the Benefits of Water Quality Improvements Under the Water Framework Directive: Are Benefits Transferable? Europ Rev Agr Econ. 33, 391-413.

Hanley. N., Wright, R.E., varez-Farizo, B., 2006. Estimating the Economic Value of Improvements in River Ecology Using Choice Experiments: An Application to the Water Framework Directive. J Environ Man. 78, 183-93.

Hanley, N., Schlapfer, F. and Spurgeon, J., 2003. Aggregating benefits of environmental improvements: distance-decay functions for use and non-use values, J Environ Man. 68, 297-304

Hausman, Jerry A. \& Ruud, Paul A., 1987. Specifying and Testing Econometric Models for Rank-Ordered Data. Journal of Econometrics. 34, 83-104.

Highsmith, R.C., 1982. Reproduction by Fragmentation in Corals. Marine Ecology

Progress Series. 7, 207-226. http://dx.doi.org/10.3354/meps007207 
Hudson, D., L.-H. Seah, D. Hite, and T. Haab. 2004. Telephone presurveys, selfselection, and non-response bias to mail and internet surveys in economic research. Applied Economics Letters 11:237-240.

Hughes, T.P., Baird, A.H., Bellwood, D.R., Card, M., Connolly, S.R., Folke, C., Grosberg, R., Hoegh-Guldberg, O., Jackson, J.B.C., Kleypas, J., Lough, J.M., Marshall, P., Nyström, M., Palumbi, S.R., Pandolfi, J. M., Rosen, J.M., Roughgarden, J.M.J., 2003. Climate Change, Human Impacts, and the Resilience of Coral Reefs. Science 301, 929933. DOI: $10.1126 /$ science. 1085046.

Hunter, P. D., Hanley, N., Czajkowski, M., Mearns, K., Tyler, A. N., Carvalho, L., \& Codd, G. A., 2012. The Effect of Risk Perception on Public Preferences and Willingness to Pay for Reductions in the Health Risks Posed by Toxic Cyanobacterial Blooms. Science of the Total Environment, 426, 32-44. https://doi.org/10.1016/j.scitotenv.2012.02.017

Jackson, J.B.C., 1997. Reefs since Columbus. Coral Reefs. 16, S23-S32.

Jackson, J.B.C., 1992. Pleistocene Perspectives of Coral Reef Community Structure. Am. Zool. 32, 719-731.

Johannes, R.E., 1975. Pollution and Degradation of Coral Reef Communities. In: Ferguson Wood, E.J., Johannes, R.E. (Eds.), Tropical Marine Pollution. pp. 13-50

Johns, G.M., Leeworthy, V.R., Bell, F.W., Bonn, M.A., 2003. Socioeconomic Study of Reefs in Southeast Florida, Final Report October 2001 and revised June 2003. Report for Broward, Palm Beach, Miami Dade and Monroe Counties, Florida Fish and Wildlife Conservation Commission, National Oceanic and Atmospheric Administration. http://marineeconomics.noaa.gov/Reefs/02-01.pdf.

Johnson, M.E., Lustic, C., Bartels, E., Baums, I.B., Gilliam, D.S., Larson, E.A., Lirman, D., Miller, M.W., Nedimeyer, K., Schopmeyer, S., 2011. Caribbean Acropora Restoration Guide: Best Practices for Propagation and Population Enhancement. The Nature Conservancy. Arlington, VA.

Jones GP, Syms C., 1998. Disturbance, Habitat Structure and the Ecology of Fishes on Coral Reefs. Australian J Ecol. 23, 287-297

Kraus, N., Malmfors, T., Slovic, P., 1992. Intuitive Toxicology — Expert and Lay Judgments of Chemical Risks. Risk Anal. 12, 215-232.

Krutilla, J.V., 1967. Conservation Reconsidered. American Economic Review. 57, 777786. 
Ladenburg, J. and Olsen, S.B., 2008. Gender-Specific Starting Point Bias in Choice Experiments: Evidence from an Empirical Study. J Enviro Econ and Management $56: 275-285$.

Lauck, T., Clark, C.W., Mangel, M., Munro, G.R., 1998. Implementing the Precautionary Principle in Fisheries Management Through Marine Reserves. Ecological Applications 8, S72-S78.

Leeworthy, V.R., Wiley, P.C., Hospital, J.D., 2004. Importance-Satisfaction Ratings Five-year Comparison, SPA \& ER Use, and Socioeconomic and Ecological Monitoring Comparison of Results 1995-96 to 2000-01. Silver Spring (MD): National Oceanic and Atmospheric Administration, 67 pp.

Leeworthy, V.R., Wiley, P.C., 1997. A Socioeconomic Analysis of the Recreation Activities of Monroe County Residents in the Florida Keys/Key West. Silver Spring (MD): National Oceanic and Atmospheric Administration. 〈http://marineeconomics.noaa.gov/SocmonFK/publications/97-18.pdf>

Leeworthy, V. R., 1991. Recreational Use Value for John Pennekamp Coral Reef State Park and Key Largo National Marine Sanctuary. National Oceanic and Atmospheric Administration. Rockville, MD.

Li, H., Berrens R.P., Bohara A.K., Jenkins-Smith, H., Silva, C.L., Weimer, D.L., 2005. Testing for Budget Constraint Effects in a National Advisory Referendum Survey on the Kyoto Protocol. Journal of Agricultural and Resource Economics 30:2, 350-366.

Lirman, D., Thyberg, T., Herlan, J., Hill, C., Young-Lahiff, C., Schopmeyer, S., Huntington, B., Santos, R., Drury, C., 2010. Propagation of the Threatened Staghorn Coral Acropora cervicornis: Methods to Minimize the Impacts of Fragment Collection and Maximize Production. Coral Reefs. 29, 729-735. DOI: 10.1007/s00338-010-0621-6.

Lirman, D., Schopmeyer, S., Galvan, V., Drury, C., Baker, A.C., Baums, I.B., 2014. Growth Dynamics of the Threatened Caribbean Staghorn Coral Acropora cervicornis: Influence of Host Genotype, Symbiont Identity, Colony Size, and Environmental Setting. PLoS ONE 9(9): e107253. https://doi.org/10.1371/journal.pone.0107253.

Lirman, D., 1999. Reef Fish Communities Associated with Acropora Palmata:

Relationship to Benthic Attributes. Bulletin of Marine Science. 65:1, 235-252.

Loomis, J.B., 1996. How Large is the Extent of the Market for Public Goods: Evidence from a Nationwide Contingent Valuation Survey. Applied Economics. 28, 779-782. 
Marta-Pedroso, C., Freitas, H., Domingos, T., 2007. Testing for the Survey Mode Effect on Contingent Valuation Data Quality: A Case Study of Web Based Versus In-person Interviews. Ecological Economics. 62:388-398.

May, H., Burger J., 1996. Fishing in a Polluted Estuary: Fishing Behaviour, Fish Consumption, and Potential Risk. Risk Anal. 16, 459-71.

McAllister, D.E., 1991. What is the Status of the World's Coral Reef Fishes? Sea Wind. $5,14-18$.

McClanahan, T.R., Mangi, S., 2000. Spillover of Exploitable Fishes from a Marine Park and its Effect on the Adjacent Fishery. Ecological Applications. 10, 1792-1805.

McFadden, D., 1973. Conditional Logit Analysis of Qualitative Choice Behavior. In P. Zarembka (ed.), Frontiers in Econometrics, Academic Press, New York.

Millennium Ecosystem Assessment. 2005. Ecosystems and Human Well-Being. Washington, DC: Island Press. Available from $<$ http://www.millenniumassessment.org/documents/document.356.aspx.pdf>

Miller, M., Bourque, A., Bohnsack, J., 2002. An Analysis of the Loss of Acroporid Corals at Looe Key, Florida, USA: 1983-2000. Coral Reefs. 21:2, 179-182.

Miller, S.L., Chiappone, M., Rutten, L.M., Swanson, D.W., 2008. Population Status of Acropora Corals in the Florida Keys. Proceedings of the 11th International Coral Reef Symposium, pp. 775-779.

Milon, J.W., Adams, C.M., Carter, D.W., 1998. Floridians' Attitudes About the Environment and Coastal Marine Resources. Florida Sea Grant College Program. Moberg, F.F., Folke, C., 1999. Ecological Goods and Services of Coral Reef Ecosystems. Ecological Economics. 29, 215-233.

Mumby, P.J., Harborne, A.R. , Williams, J., Kappel, C.V., Brumbaugh, D.R., Micheli, F., Holmes, K.E., Dahlgren, C.P., Paris, C.B., Blackwell, P.G. Trophic Cascade Facilitates Coral Recruitment in a Marine Reserve. 2007. Proceedings of the National Academy of Sciences 104:20 8362-8367. www.pnas.orgcgidoi10.1073pnas.0702602104.

NMFS (National Marine Fisheries Service). 2006. Endangered and Threatened Species: Final Listing Determinations for Elkhorn Coral and Staghorn Coral. 71 FR 26852.

NMFS. 2008. Endangered and Threatened Species; Critical Habitat for Threatened Elkhorn and Staghorn Corals. 73 FR 72210. 
NMFS. 2014. Fisheries Economics of the United States, 2012. U.S. Dept. Commerce, NOAA Tech. Memo. NMFS-F/SPO-137, 175p. Available at:

https://www.st.nmfs.noaa.gov/st5/publication/index.html.

NMFS. 2015. Recovery Plan for Elkhorn (Acropora palmata) and Staghorn (A. cervicornis) Corals. Prepared by the Acropora Recovery Team for the National Marine Fisheries Service, Silver Spring, Maryland.

NOAA. 2007. Florida Keys National Marine Sanctuary Revised Management Plan.

Obura, D.O., Grimsdith, G., 2009. Resilience Assessment of Coral Reefs- Assessment Protocol for Coral Reefs, Focusing on Coral Bleaching and Thermal Stress. IUCN working group on Climate Change and Coral Reefs. IUCN, Gland, Switzerland.70 pages.

Olsen, S.B., 2009. Choosing Between Internet and Mail Survey Modes for Choice Experiment Surveys Considering Non-Market Goods. Environmental and Resource Economics 44:591-610.

Pandolfi, J.M., 2002. Coral Community Dynamics at Multiple Scales. Coral Reefs. 21, $13-23$.

Pandolfi, J.M., Jackson, J.B.C., 2006. Ecological Persistence Interrupted in Caribbean Coral Reefs. Ecological Letters. 9, 818-826.

Pate, J., Loomis, J., 1997. The Effect of Distance on Willingness to Pay Values: A Case Study of Wetlands and Salmon in California. Ecological Economics. 20:3, 199-207.

Peterson, C.H., Lubchenco, J., 1997. On the Value of Marine Ecosystems to Society. In: Daily, G.C. (Ed.), Nature's Services. Societal Dependence on Natural Ecosystems. Island Press, New York, pp. 177-194.

Pittman, S.J., Christensen, J., Caldow, C., Menza, C., Monaco, M., 2007. Predictive Mapping of Fish Species Richness Across Shallow-Water Seascapes of the U.S.

Caribbean. Ecol Model. 204, 9-21.

Precht, W.F., 2006. Coral Restoration Handbook. CRC Press. p. 384.

Principe, P. P., Bradley, P., Yes, S. H., Fisher, W.S., Johnson, E. D., Allen, P., Campbell, D.E., 2012. Quantifying Coral Reef Ecosystem Services. U.S. Environmental Protection Agency, Washington, DC, EPA/600/R-11/206.

Reaka-Kudla, M.L., 1994. Biodiversity of Coral Reefs. In: Heasley, C. (Ed.), Science and a Changing World. p. 22. 
Reid-Grant, K., Bhat, M., 2009. Financing Marine Protected Areas in Jamaica: An Exploratory Study. Marine Policy. 33, 128-136.

Richardson, L., Loomis, J., 2009. The Total Economic Value of Threatened, Endangered and Rare Species: An Updated Meta-analysis. Ecological Economics. 68, 1535-1548.

Rinkevich, B., 2005. Conservation of Coral Reefs through Active Restoration Measures: Recent Approaches and Last Decade Progress. Environ. Sci. Technol. 39:12, 4333-4342. DOI: $10.1021 /$ es0482583.

Rinkevich, B., 1995. Restoration Strategies for Coral Reefs Damaged by Recreational Activities: The Use of Sexual and Asexual Recruits. Restoration Ecology. 3, 241-251. http://dx.doi.org/10.1111/j.1526-100X.1995.tb00091.x

Roberts, C.M., 1995. Effects of Fishing on the Ecosystem Structure of Coral Reefs. Conserv. Biol. 9:5, 988-995.

Rohmann, S.O., Hayes, J.J., Newhall, R.C., Monaco, M.E., Grigg, R.W., 2005. The Area of Potential Shallow-Water Tropical and Subtropical Coral Ecosystems in the United States. Coral Reefs. 24:3, 370-383.

Samples, K. C., Dixon J.A., Gowen M.M., 1986. Information Disclosure and Endangered Species Valuation. Land Economics 62, 306-312.

Sanchirico, J.N., K.A. Cochran and P.M. Emerson. 2002. Marine Protected Areas: Economic and Social Implications. Washington D.C.: Resources for the Future.

Schopmeyer, S., Lirman, D., Bartels, E., Gilliam, D.S., Goergen, E., Griffin, S.P., Johnson, M.E., Lustic, C., Maxwell, K., Walter, C., 2017. Regional Restoration Benchmarks for Acropora cervicornis. Coral Reefs. 4, 1047-1057. https://nsuworks.nova.edu/occ_facarticles/904.

Selig, E.R., Bruno, J.F., 2010. A Global Analysis of the Effectiveness of Marine Protected Areas in Preventing Coral Loss. PLoS ONE 5:2, e9278. https://doi.org/10.1371/journal.pone.0009278.

Shafir, S., Van Rijn, J., Rinkevich, B., 2006. Steps in the Construction of an Underwater Coral Nursery, an Essential Component in Reef Restoration Acts. Marine Biology. 149, 679-687. http://dx.doi.org/10.1007/s00227-005-0236-6.

Shafir, S., Rinkevich, B., 2008. The Underwater Silviculture Approach for Reef Restoration: An Emergent Aquaculture Theme. In: Schwartz SH, editor. Aquaculture research trends. 1st ed. New York: Nova Scientific Publishers, Inc. p. 279-295. 
Shaish, L., Levy, G., Gomez, E., Rinkevich, B., 2008. Fixed and Suspended Coral Nurseries in the Philippines: Establishing the First Step in the "Gardening Concept" of Reef Restoration. Experimental Marine Biology and Ecology. 358, 86-97. http://dx.doi.org/10.1016/j.jembe.2008.01.024.

Slovic P., 1987. Perception of Risk. Science. 236, 280-5.

Smith, S.V., 1978. Coral Reef Area and the Contributions of Reefs to Processes and Resources of the World's Oceans. Nature. 273:5659, 225-226.

Sobel, J., Dahlgren, C., 2004. Marine Reserves: A Guide to Science, Design, and Use. Washington, DC, USA: Island Press.

Sorokin, Y.I., 1993 (Ed.). Coral Reef Ecology. Ecological Studies 102. Springer. pp. 428.

Spalding, M., Burke, L., Wood, S.A., Ashpolee, J., Hutchison, J., zu Ermgassene, P., 2017. Mapping the Global Value and Distribution of Coral Reef Tourism. Marine Policy. $82,104-113$.

Stefanski, S., Shimshack, J.P., 2015. Valuing Marine Biodiversity in the Gulf of Mexico: Evidence from the Proposed Boundary Expansion of the Flower Garden Banks National Marine Sanctuary. Duke University PhD Thesis.

Sukharomana, R., Supalla, R., 1998. Effect of Risk Perception on Willingness to Pay for Improved Water Quality. Presentations, Working Papers, and Gray Literature: Agricultural Economics. Paper 46.

Sutherland, R.J., Walsh, R., 1985. Effect of Distance on the Preservation Value of Water Quality. Land Econ. 61, 281-291.

Thurstone, L.L. 1935. The Vectors of the Mind. Chicago, IL: University of Chicago Press.

Thurstone, L.L. 1927. A Law of Comparative Judgement. Psychological Review. 4, 273 286.

Tsuge, T., Washida, T., 2003. Economic Valuation of the Seto Inland Sea by Using an Internet CV Survey. Marine Pollution Bulletin. 47, 230-236.

Turner, R. 2017., Travel \& Tourism, Economic Impact 2017, Caribbean (Report). World Travel and Tourism Council. p. 1. Retrieved 2018-7-18. 
Turner, R. K., Van Den Bergh, J. C. J. M., Söderqvist, T., Barendregt, A., Van Der Straaten, J., Maltby, E., Van Ierland, E. C., 2000. Ecological-Economic Analysis of Wetlands: Scientific Integration for Management and Policy. Ecological Economics. 35:1, 7-23. https://doi.org/10.1016/S0921-8009(00)00164-6

Veronesi, M., Chawla, F., Maurer, M., Lienert, J., 2014. Climate Change and the Willingness to Pay to Reduce Ecological and Health Risks from Wastewater Flooding in Urban Centers and the Environment. Ecological Economics. 98, 1-10.

Vignola, R., Klinsky, S., Tam, J., McDaniels, T. 2013. Public Perception, Knowledge and Policy Support for Mitigation and Adaption to Climate Change in Costa Rica: Comparisons with North American and European Studies. Mitigation and Adaptation Strategies for Global Change. 18:3, 303-323. https://doi.org/10.1007/s11027-012-9364-8.

Walker, B.K., Jordan, L.K.B., Spieler, R.E., 2009. Relationship of Reef Fish Assemblages and Topographic Complexity on Southeastern Florida Coral Reef Habitats. Journal of Coastal Research. 53, 39-48.

Warren-Rhodes K., Sadovy Y.J., Cesar, H., 2003. Marine Ecosystem Appropriation in the IndoPacific: A Case Study of the Live Reef Fish Food Trade. Ambio. 32:7, 481-488.

Weber, E.U., Blais, A.R., Betz, N., 2002. A Domain-Specific Risk-Attitude Scale: Measuring Risk Perceptions and Risk Behaviors. Journal of Behavioral Decision Making. $15,1-28$.

Weber E. U., Hsee, C. K. 1999. Models and Mosaics: Investigating Cross-Cultural Differences in Risk Perception and Risk Preference. Psychonomic Bulletin \& Review. 6, 611-617.

Wilkinson, C.R., 1996. Global Change and Coral Reefs: Impacts on Reefs and Human Cultures. Global Change Biology. 2:6, 547-558. DOI: 10.1111/j.1365-

2486.1996.tb00066.x.

Wilkinson, C., 2004. Status of Coral Reefs of the World. Global Coral Reef Monitoring Network and Australian Institute of Marine Science. 557pp.

Wilkinson, C., 2008. Status of Coral Reefs of the World. Global Coral Reef Monitoring Network and Reef and Rainforest Research Centre. 296 p.

Wilkinson, C.R., Buddemeier, R.W., 1994. Global Climate Change and Coral Reefs: Implications for People and Reefs. Report of the UNEP-IOC-ASPEI-IUCN Global task team on the implications of climate change on coral reefs, IUCN, Gland, Switzerland, pp. 124. 
WTTC, 2017. World Travel and Tourism Council. Travel and Tourism Global Economic Impact and Issues 2017. https://www.wttc.org/-/media/files/reports/economic-impactresearch/2017-documents/global-economic-impact-and-issues-2017.pdf. Accessed $7 / 18 / 2018$.

Young, C.N., Schopmeyer, S., Lirman, D., 2012. A Review of Reef Restoration and Coral Propagation Using the Threatened Genus Acropora in the Caribbean and Western Atlantic. Bulletin of Marine Science. 88, 4. DOI: 10.5343/bms.2011.1143.

Zaneveld, J.R., Burkepile, D.E., Shantz, A.A., Pritchard, C.E., McMinds, R., Payet, J.P., Welsh, R., Correa, A.M.S., Lemoine, N.P., Rosales, S. Fuchs, C., Maynard, J.A., Vega Thurber, R., 2016. Overfishing and Nutrient Pollution Interact with Temperature to Disrupt Coral Reefs Down to Microbial Scales. Nature Communications. 7:11833. DOI: 10.1038/ncomms11833. 
Chapter 3: Cost-benefit analysis of restocking staghorn coral on the Florida Reef

\subsection{Introduction}

Coral reef ecosystems on the Florida Reef Tract (FRT) provide critical habitat for thousands of species and recreational and spiritual opportunities for millions of people every year. Proximity to the Miami metropolitan area and Florida Keys has subjected the reef ecosystem to decades of intense human use, deteriorating water quality, coral bleaching and diseases, loss of living coral cover, and declining reef fish populations. Once among the most ecologically dominant structure building corals on reefs in the Caribbean and SW Atlantic, staghorn coral has declined in abundance an estimated 97\% regionally since the 1970s (Goreau, 1959; Geister, 1977; Adey, 1978; Jackson, 1992; Pandolfi, 2002; Pandolfi and Jackson, 2001; NMFS, 2015). Today, staghorn corals occur as isolated colonies or fragments primarily on isolated patch reefs as opposed to their former abundance in deeper forereef habitats (Miller et al., 2008). Local fisheries have declined in productivity over the same period as the decline in staghorn coral abundance. Total commercial landings on the east coast of Florida dropped from 30,039 metric tons in 1980 to 9,769 in 2016, a reduction of $67.39 \%$, and 23 of 35 species of groupers, snappers, hogfish, and grunts have been chronically over-fished since the 1970s according to National Marine Fishery Service (NMFS) standards (Ault, 1998).

Leeworthy and Bowker (1997) estimated 13.7 million visitor days, worth annual non-market use value of over $\$ 1.2$ billion, are spent annually in the Florida Keys, $75 \%$ of which is derived from natural resource-based activities like snorkeling, scuba diving and fishing. The inextricable linkages between the economy and health of its coastal 
ecosystems and make management and protection of the Florida Keys' existing resources critical to the future of the island chain.

In response to the precipitous decline of regional populations and listing as "threatened" under the Endangered Species Act in 2006, the National Marine Fisheries Service (NMFS) formulated a recovery plan for the species (NMFS, 2015). Proposed recovery actions include propagating staghorn coral colonies in underwater nurseries and transplanting them onto denuded reefs along the FRT and establishment of no-take marine reserves to protect remaining natural and restocked populations. Both recovery actions are expected to increase sexual reproduction and support the long-term recovery of wild staghorn populations and their genetic diversity (NMFS, 2015). The abundance recovery criteria established in the recovery plan for staghorn coral (NMFS, 2015) is that thickets exist across approximately 5 percent of consolidated reef habitat in 5 to $20 \mathrm{~m}$ water depth within the fore reef zone; thickets are defined as either a) colonies $\geq 0.5 \mathrm{~m}$ diameter in size at a density of 1 colony per $\mathrm{m}^{2}$ or b) live staghorn coral benthic cover of approximately 25 percent. Recovery of staghorn populations has been estimated to require 400 years at a cost exceeding $\$ 250,000,000$ (NMFS, 2015).

Over the past decade, more than 100,000 staghorn colonies have been outplanted at over 100 sites on the FRT and approximately 50,000 staghorn colonies are expected to be transplanted annually over the foreseeable future. Outplanting capacity has been largely determined and limited by the availability of funding and achieving the recovery criteria established in the recovery plan will likely require substantial increases in annual outplant volume from current numbers. Positive changes in the structure and function of the coral reef ecosystem as outplants mature are expected to enhance recreational 
opportunities for recreational users and affect the population dynamics of most commercially harvestable reef fish species and, thus, fisheries productivity and revenue. Several studies have examined visitor preferences and the tourism and recreational value of coral reef habitat in the Caribbean and Florida Keys (e.g., Bhat, 2003), however, none have focused explicitly on the values supported by staghorn corals or attempted a costbenefit analysis of restocking and protecting regional populations. Cost-benefit analysis can provide insights into the economic efficiency of management and regulatory actions; management or regulatory actions with benefits exceeding costs are considered economically efficient.

Using a bioeconomic model (Conrad, 1999) of a multi-stock fishery and stated preference valuation techniques, the first two chapters of this research attempt to apply the ecosystem service valuation process to monetize the value of restocking and protecting staghorn populations on the FRT considering two of the most important directuse values supported by staghorn coral in the Florida Keys, commercial reef fish fishing and recreational diving. Specifically, this study forecasts and evaluates the change in the value of the selected ecosystem services between the future with restocking at current numbers (i.e., 50,000 outplants $\mathrm{yr}^{-1}$ ), the future with restocking at current numbers and marine reserves protecting transplanted colonies (referred to hereafter as the "combined" program), and the future without restocking. The objective of this chapter is to synthesize the valuation results of the first two chapters and examine the business case for restocking and protecting staghorn corals on a large scale. Because we limit our analysis to "direct" use values, and do not consider "indirect" use or "non-use" values, this study represents a conservative cost-benefit analysis. 
Cost-benefit analyses comparing the benefits of preserving or enhancing environmental resources with the opportunity costs for alternative decisions has become widely practiced over the past several decades and is recognized as the primary appraisal method for public investments and public policy (Farrow and Toman, 1998). An understanding of the multiple ecosystem service benefits and tradeoffs associated with staghorn restocking can support restoration efforts in several ways, including improving site selection and design, increasing stakeholder buy-in for restoration projects, enhancing the ability to leverage funding opportunities, and enabling the evaluation of the project in terms of economic efficiency. To our knowledge, this study represents a first attempt to incorporate simulated changes in staghorn abundance over time from recovery efforts into an ex-ante ES valuation framework.

\subsection{Methodology}

\subsection{Theoretical Framework}

The Millennium Ecosystem Assessment (MEA) defines "Ecosystem Services" (ES) as "the benefits people obtain from ecosystems" (MEA, 2005). Ecosystem services can be organized in terms of uses of value to human populations (Table 30), and examined in quantitative or qualitative terms, or through economic valuation. Economic valuation of ES attempts to identify the ways ES benefit humans and monetize these benefits for comparison to other sources of value to society (Principe et al., 2015) and is commonly used to support policy and decision makers in making investment and policy decisions (Waite et al., 2014). 
Often, no formal markets exist for the goods and services provided by environmental resources, so their monetary values to people may not be readily observable. In such cases, a common approach to valuing changes in the quantity or quality of ES flowing from an environmental asset involves eliciting people's preferences for changes in the state of their environment. To estimate the ex-ante recreational diving value associated with restocking and protecting staghorn coral populations, we applied two attribute-based stated preference (SP) methods. Stated preference methods are commonly used in environmental valuation to gather data about respondent preferences for environmental amenities, typically through hypothetical scenarios presented in a survey format. Because SP preference techniques enable examination of public preferences for provision levels of goods or services that differ from levels observed currently or in the past, they are often the only approach available for providing the economic valuation inputs required for cost-benefit analysis. The results presented in this study were quantified in terms of the public's mean WTP (2017 \$US) per hectare of rehabilitated coral reef with, and without, a marine reserve protecting restocked colonies.

To quantify the ecological and economic commercial reef fish fishery benefits supported by increased staghorn coral abundance, we modify a standard bioeconomic model of a multi-species fishery to allow for the influence of habitat on the commercial reef fish stock. A staghorn coral support function is included in the intertemporal bioeconomic harvesting problem through the growth function of the fish stock; impacts of a change in the support function were quantified in terms of changes in the long-run equilibrium conditions of the fishery with, and without, a marine reserve to protect transplanted staghorn colonies. This general methodology for quantifying staghorn- 
fishery linkages and the impacts of staghorn abundance and no-take marine reserves protecting rehabilitated reefs on the equilibrium conditions of the fishery can be applied regionally to staghorn restoration projects.

As mentioned previously, we limit our cost benefit analysis to the examination of two of the primary direct uses expected to benefit from enhanced staghorn abundance, commercial reef fish fishing and recreational diving. Accordingly, the valuation results presented here reflect only a partial accounting of the benefits anticipated from ongoing staghorn recovery efforts.

2.2 Estimating changes to ES values from restocking and protecting staghorn corals

\subsubsection{Recreational Diving Value}

To derive the contribution of recreational diving to the total value of staghorn restoration and protection, we administered a household survey to elicit the preferences and level of support of residents of the southeastern United States for restocking and protecting Florida's staghorn coral populations. The survey included a choice model that enabled estimation of the respondents' WTP for three hypothetical management alternatives. Residents of Florida, Alabama, Georgia, and Mississippi $(n=3,135)$ were randomly selected to complete the survey; One-thousand and sixty-one surveys were completed and retained for analysis. In the survey instrument, each alternative is described in terms of its features or "attributes". Described attributes included: (i) the number of staghorn colonies outplanted on the FRT annually and estimated area of coral reef rehabilitated after 30 years of outplanting, (ii) the area of new marine reserves protecting outplanted corals, and (iii) cost of each alternative to the respondent. Attributes had two levels apiece: the status quo or some positive action. The status quo alternative 
consisted of the current level of outplanting (approximately 50,000 colonies $\mathrm{yr}^{-1}$ ) continuing for at least 30 years with no new marine reserves to protect outplanted colonies; the positive actions consisted of: (1) increase staghorn outplants on the FRT from the current annual average of approximately 50,000 to 300,000, (2) implement notake marine reserves to protect the 50,000 colonies currently outplanted every year, (3) increase staghorn outplants on the FRT from the current annual average of approximately 50,000 to 300,000 and implement no-take marine reserves to protect outplanted corals. For the combined program, existence of the marine reserve to protect outplanted corals was assumed to boost the intrinsic rate of growth of the commercially important reef fish stock from .2 to .3 . The growth and area of outplanted colonies was simulated $A=\pi A B$, where $A$ and $B$ are one-half of the colony major and minor axis, respectively. Outcomes were characterized in terms of reef area rehabilitated with outplanted colonies upon reaching $54.31 \%$ coverage in the restoration site, the $95^{\text {th }}$ percentile staghorn coverage estimated from an observational dataset of staghorn colony size and abundance and reef fish species, length and abundance collected in the Dry Tortugas from 2012-2014 (Miller and Huntington, 2015). Willingness-to-pay values derived from survey responses reflect the amount households were willing to pay, in 2017 dollars, for program outcomes. As with many public investments, the anticipated benefits of rehabilitating reefs with nursery-reared staghorn colonies will be realized at some future date, whereas most of the costs are incurred initially. Because the ecological value of newly outplanted staghorn colonies is negligible relative to their value upon maturity and full value is realized only upon reaching ecological equilibrium, we adjusted WTP values to account for the area of 
staghorn coverage at the restoration site as a percentage of the derived carrying capacity of $54.31 \%$. To do this we follow the following steps:

(i) converted household WTP values to per-hectare WTP values

$W T P_{h a}=\frac{W T P_{H H}}{\text { area }}$

where $W T P_{h a}$ is per the per-hectare WTP value, $W T P_{H H}$ is household WTP derived from the rank order logit results presented in Table 25, and area is the hectares of rehabilitated reef containing outplanted staghorn corals.

(ii) derived inflation-adjusted WTP values for years one through 30

$W T P_{t}=(1+r) * W T P_{t-1}$

where $W T P_{t}$ is per hectare WTP in period tand $r$ is the mean rate of inflation in the US from 2009-2018, 1.65\%; and

(iii) took the product of the ratio of staghorn coverage to carrying capacity and perhectare WTP to arrive at an area, or coral growth-adjusted WTP value:

$W T P_{a d j, t}=W T P_{t} * \frac{\text { cover }_{t}}{K}$

where $W T P_{a d j, t}$ is the area adjusted WTP at time $t, W T P_{t}$ is inflation adjusted per-

hectare WTP at time $t$, cover $_{t}$ is the percent coral cover at the project site at time $t$, and $K$ is the site carrying capacity of $54.31 \%$ staghorn coverage.

Extrapolating the adjusted per hectare WTP values for the alternative programs to the estimated population of certified open-water scuba divers in Florida (www.dema.org), we derived the contribution of recreational diving to the total economic value of staghorn recovery efforts.

Because divers are direct users of coral reefs whose consumer surplus has been shown to be enhanced by the health of the coral reef ecosystems they visit (Bhat, 2002), 
we felt like the recreational diving benefits supported by staghorn restocking represented the true project value, rather than a value derived from a larger population of users and non-users like the population of South Florida, for example.

\subsubsection{Commercial reef-fish fishery value}

We applied a deterministic bioeconomic model of a multispecies fishery (Conrad, 1999) that accounts explicitly for the effect of staghorn coral coverage on commercially harvestable reef fish biomass and productivity to quantify changes in the optimal equilibrium commercial reef fish stocks, harvest rate and profit from restocking and protecting staghorn coral populations. The model is spatially implicit, in that the precise relative location of each restoration site is not specified. Because stocks of the most economically important commercially harvested reef fish in Florida are managed, we examine equilibrium conditions characterizing maximum economic yield (MEY), or the stocks and harvest which maximize economic benefits to society, rather than that of an open-access fishery. Key parameters were estimated from existing datasets of regionally collected staghorn and reef fish size and abundance (Miller and Huntington, 2015; SEFSC, 2016). Bioeconomic model parameters requiring estimation included: (1) annual changes in rehabilitated reef area covered by outplanted staghorn colonies at the simulated restoration site resulting from restocking and protection, (2) baseline abundance of commercially important reef fish on the FRT inside and outside of areas prohibiting consumptive activities, (3) reef fish carrying capacity in the study area, (4) harvest cost, and; (5) the biophysical relationship between staghorn coral area and reef fish biomass. 
To estimate the change in area of staghorn corals over time resulting from outplanting, we developed a simple linear staghorn growth model. For our baseline bioeconomic model run, the results presented here, we assume, at the time of outplanting, simulated colonies are elliptical in shape, $25 \mathrm{~cm}$ in length. Change in outplanted staghorn area was simulated following the equation for the area of an ellipse (Kiel, 2014), Area $=\pi A B$

where $A$ and $B$ are one-half the length and width of the colony's major and minor axis, respectively. Simulated colonies are assumed to be outplanted in a grid pattern at a uniform density of 10,000 outplants per hectare (ha) and assumed to maintain an annual major axis growth rate of $5 \mathrm{~cm}$; published staghorn linear growth ranges from 3 to 11.5 cm yr ${ }^{-1}$ (Shinn 1966, Gladfelter et al. 1978).

We cap colony length at $100 \mathrm{~cm}$ (at which point colonies begin to interlock at the simulated treatment area and the marginal ecological value of continued growth declines) and cap coverage to $54.31 \%$ of the treatment area, the 95 th percentile estimated from the Miller and Huntington (2015) dataset. Simulated outplants in the baseline scenario experience first and second year mortality of $15 \%$ and $10 \%$, and none thereafter (Schopmeyer et al, 2017).

To derive baseline reef fish biomass and carrying capacity in the study area, we use an observational dataset of reef fish counts and measures inside and outside of notake marine reserves in the FKNMS (SEFSC, 2016). We use the median biomass estimates as parameters representing fishery carrying capacity prior to restocking.

With double log-linear regression we quantify the biophysical relationship between staghorn coral coverage and reef fish biomass using a dataset of reef fish and 
staghorn colony measures and abundance collected between 2012-2014 from underwater visual surveys ( $\mathrm{n}=65$ transects) in the Dry Tortugas National Park, a relatively rich coral reef ecosystem at the western tip of the Florida Keys (Miller and Huntington, 2015)

Using the ex-ante estimates of outplanted staghorn coverage from the coral growth model, reef fish abundance and carrying capacity estimated from the SEFCS (2016) datasets, harvest costs derived from data queried by provided by professionals within the Fisheries Monitoring Branch (FMB) of the Southeast Fisheries Science Center (SEFSC) in Miami, Florida, market fish prices, and fish stock growth from peer reviewed literature (Froese and Pauly, 2018), and estimated diffusion coefficient, the model enables characterization of the linkages between coral abundance, commercial reef fish stocks and optimal sustainable harvest. A detailed solution of the bioeconomic model is contained in Chapter One.

\subsection{Results and discussion}

The monetized value of the subset of ecosystem services affected by restocking and protecting staghorn corals that are examined by this study are shown in Tables 31 and 32. In Table 31, household WTP results are presented for 300,000 $25 \mathrm{~cm}^{2}$ colonies outplanted annually for 30 years. The bioeconomic model annual WTP values were discounted at a 4\% discount rate to arrive at the discounted NPV in Table 31 and reveal the incremental benefit of management alternatives (restocking and protection) over no staghorn restocking. Table 33 presents mean household WTP results for a one-time planting of 50,000 $25 \mathrm{~cm}^{2}$ staghorn colonies under each of the two management alternatives, extrapolated to the mean population of certified open water scuba divers in 
Florida over the past three years. Results confirm that recreational values are dramatically larger than commercial reef fish fishery values.

The adjusted per hectare annual WTP values are presented in Table 34. Because outplanted colonies do not reach their carrying capacity until year 22, adjusted values are less than base values for years 1-22 and reach base values in year 22, at which staghorn coverage reaches its assumed carrying capacity of $54.31 \%$ of the restocked reef (Figure 8). Project net present values for 50,000 staghorn colonies outplanted annually for 30 years are presented in Table 35. Values were derived by extrapolating adjusted WTP values to the various relevant populations and accounting for costs of production, outplanting, and two years of monitoring (Coral Restoration Foundation, personal communication). Corresponding benefit-cost ratios and sensitivity analysis are presented in Table 36. Results suggest project values may be substantial, and benefit-cost ratios may be greater than one, suggesting economic efficiency, depending on the relevant population considered. A description of all the ecosystem services supported by staghorn corals is contained in Table 29. As noted previously, the services valued with this study represent a subsample of those supported by staghorn corals.

\subsection{Management implications and conclusions}

The work presented here is consistent with previous research revealing that rehabilitation and restoration of ecosystems and the goods and services provided can yield significant contributions to society and to economies, and highlights some of the key challenges when attempting to monetize the value of ecosystem services. This study focuses on two of the most important direct use values supported by increased staghorn coral abundance in the Florida Keys, commercial reef fish fishing and recreational diving. 
Because we examine only a subset of the ecosystem services likely to be impacted by the recovery of staghorn populations, the benefits highlighted here represent only a partial accounting of the total economic value of enhancing local populations; The economic value of several key ecosystem goods and services supported by the recovery of staghorn corals off SE Florida remain unexamined. Previous work has reported that non-use values make up a substantial portion of the TEV of coral reefs, suggesting that the values reported here provide only a small fraction of the total value of efforts to recover lost staghorn populations.

Future research examining the impact of staghorn restocking on the recreational fishing industry and the provision of physical coastal protection, for example, could fill some of the remaining gaps in our understanding of the total economic value of coral restoration efforts. More than half of the economy of the Keys is supported by ocean recreation and tourism. Given the strong economic linkages between marine ecosystem health and the rest of the economy, an ex-ante input-output analysis accounting for multiplier effects in the local and regional economies impacted by staghorn restocking may shed more light on the net total economic value of recovering lost staghorn populations as well as contributions to individual sectors of the Florida Keys economy.

Coastal ecosystems provide a substantial proportion of the population of Florida physical protection from the impacts of strong tropical storms. An examination of the contribution of staghorn restocking to the coastal protection value of the FRT can also further our understanding of the TEV of recovering staghorn populations. As sea-level rise continues, the intensity of tropical storms continues to increase with climate change 
(Bender et al., 2010), and the population of SE Florida continues to grow, the coastal protection value of staghorn recovery efforts will likely increase.

Although implementation of a comprehensive regional restocking program and marine reserves to protect staghorn populations are two of the recovery actions identified in the species recovery plan (NMFS, 2015), the management alternatives examined in this study were not based on actual proposals. Our hypothetical scenarios are simply tools to estimate the total value of restocking and protecting staghorn corals. Actual efforts to rehabilitate denuded reefs and implement new marine reserves on a large-scale in the Florida Keys will likely face various obstacles, including major gaps in reef restoration science, and social and institutional inertial resistance to change (Bohnsack, 1999).

Results of our household survey suggest a substantial percentage of the public supports efforts to enhance and protect staghorn coral populations off SE Florida. The perceived benefits of healthier coral reef ecosystems are generally positive and potential dis-benefits from coral gardening and restocking denuded reefs are considered negligible. Even with broad public support for the proposed interventions, however, distributional issues associated with marine reserves will likely result in resistance from special interests (Bohnsack, 1999). For example, extractive users may oppose restrictions prohibiting fishing on restocked reefs over concerns of potential congestion on the remaining fishing grounds, increased fuel costs, or user conflicts. A general distrust of science and management among users has impeded past efforts to establish new areas closed to consumptive activities in SE Florida (Seeteram, et al., submitted for publication) and may inhibit the implementation of new no-take marine reserves for the protection of restocked corals. Although no-take marine reserves have proven effective in 
the Florida Keys in enhancing biomass of harvested species within reserve boundaries, and research suggests diffusion of fish moving out of marine reserves may improve fishing, many would prefer a marine reserve anywhere other than where they traditionally fish. (Seeteram, et al., submitted for publication) found that $66.7 \%$ of surveyed commercial fishermen opposed expansion of no-take zones in the FKNMS due to their perception that proposed changes would hinder their current fishing operations and $23.3 \%$ of those surveyed who opposed expansion did so even if the proposed management action would not hurt their business. These findings suggest the effectiveness of efforts to recover local staghorn populations will likely depend on the ability of managers to influence the perception of local users.

Our baseline model assumption that implementation of a marine reserve would not enhance outplanted survivorship may undervalue marine reserves as a tool for staghorn and fisheries conservation. Research suggests no-take marine reserves protecting corals from damage associated with fishing gear, anchoring and other physical stressors may enhance coral survivorship, recruitment and growth (Mumby et al., 2007), however, the effectiveness of marine reserves in preserving outplanted corals in the Florida Keys has not been established. A global meta-analysis examining the effectiveness of marine reserves in protecting coral reefs found, on average, no change in coral cover on reefs protected by coral cover while reefs outside of marine reserves experienced losses in coral cover, on average (Selig and Bruno, 2010). Mumby, et al (2007) reported denuded coral reefs in the Caribbean recovered four times faster when protected by marine reserves. Variation in recovery times between protected and unprotected reefs examined as part of that study was attributed primarily to reductions in 
macroalgae cover in marine reserves from rebounding stocks of overharvested parrotfish, whereas coral cover loss off SE Florida has been attributed primarily to disease, with which marine reserves will have little to no direct impact.

Our assumptions of linear coral growth and spatial homogeneity across the area rehabilitated through outplanting are not realistic. As thickets develop, there are years of healthy growth or die off, which may be the result of disease, predation, storms, or other environmental factors, for example. Staghorn's primary mode of reproduction is through asexual fragmentation and nursery-reared colonies have been observed reproducing sexually within two years of outplanting. Because the capability to predict the contribution of reproduction to the rate of change in outplanted staghorn cover is limited, and to minimize the likelihood of overestimating changes in staghorn abundance over time in our modeling, we did not account for the contribution of reproduction, either sexual or asexual, in our coral growth model. We assume that any potential overestimation in outplant cover over time resulting from our assumptions of linear growth and spatial homogeneity will be offset by the omission of reproduction from our outplant growth simulation.

Our current capability to reliably value changes in the services and benefits flowing from restocked reefs is limited by major gaps in reef restoration science, including knowledge of critical physical and biological linkages. As our understanding of these linkages improves, our ability to more accurately characterize the relationships between staghorn abundance, the ecological functioning of coral reef ecosystems, and economic systems will also improve. 
Large-scale rehabilitation of denuded coral reef habitats is now widely considered the only hope for recovery of the coastal fisheries, biodiversity, and shoreline protection that only large healthy reefs can provide. This study represents a first step in developing a reliable valuation framework for evaluating two of the most important direct-use values affected by coral reef rehabilitation. As the science of coral reef restoration evolves and more long-term data documenting the outcomes of individual projects becomes available, some of the uncertainty endemic to this study may be reduceable. While focusing on improving our ability to enhance the structure and function of coral reef ecosystems on the FRT, the success of restoration efforts will likely depend on addressing the needs of relevant stakeholders who are often the most direct recipients of ecosystem services. By putting actual estimates of costs and benefits to restoration projects, valuation studies like this one can help inform decisions related to sustainable resource use and management. 
Table 30. Staghorn coral contributions to communities of the Caribbean region

\begin{tabular}{|l|l|}
\hline Direct extractive uses & Direct non-extractive uses \\
\hline $\begin{array}{l}\text { Commercial fishing } \\
\text { Recreational fishing } \\
\text { Aquarium trade }\end{array}$ & $\begin{array}{l}\text { Recreation (i.e., scuba diving, } \\
\text { snorkeling, } \\
\text { boating) }\end{array}$ \\
\hline Indirect uses & Nonuse values \\
\hline $\begin{array}{l}\text { Essential habitat for associated reef } \\
\text { species } \\
\text { Reef building/framework construction } \\
\text { Carbonate deposition } \\
\text { Topographical relief/complexity } \\
\text { Protection from wave action/erosion } \\
\text { Biodiversity } \\
\text { Microhabitat diversity }\end{array}$ & $\begin{array}{l}\text { Aesthetics } \\
\text { Ecientific Value }\end{array}$ \\
\hline
\end{tabular}

Adopted from: (Bruckner, 2002; Principe et al., 2015)

Table 31. HH WTP for alternative programs estimated using rank-ordered logit

\begin{tabular}{lc}
\hline Program & HH WTP \\
\hline Coral & 179.01 \\
Marine reserve & 96.60 \\
Both & 275.61 \\
\hline
\end{tabular}

Table 32. Bioeconomic model results: 5 ha treatment

\begin{tabular}{lll}
\hline Management alternative & $\begin{array}{l}\text { Discounted } \\
\text { revenue stream }\end{array}$ & $\begin{array}{l}\text { Per hectare } \\
\text { value }\end{array}$ \\
\hline No Restocking & $\$ 6,377$ & $\$ 425.13$ \\
Coral Restocking & $\$ 6,509$ & $\$ 433.94$ \\
Combined Program & $\$ 7,788$ & $\$ 519.23$ \\
\hline
\end{tabular}

One-time planting of 50,000 colonies after 30 years, 15 ha fishery 
Table 33. WTP for one-time planting of 50,000 colonies ( 5 ha) extrapolated to certified open water divers in Florida

\begin{tabular}{|c|c|c|}
\hline Year & $\begin{array}{c}\text { Coral } \\
\text { Restocking } \\
\text { Program }\end{array}$ & $\begin{array}{c}\text { Combined } \\
\text { Program }\end{array}$ \\
\hline 1 & $\$ 10,445$ & $\$ 26,971$ \\
\hline 2 & $\$ 13,534$ & $\$ 37,407$ \\
\hline 3 & $\$ 18,763$ & $\$ 51,861$ \\
\hline 4 & $\$ 24,944$ & $\$ 68,945$ \\
\hline 5 & $\$ 32,117$ & $\$ 88,770$ \\
\hline 6 & $\$ 40,324$ & $\$ 111,454$ \\
\hline 7 & $\$ 49,608$ & $\$ 137,115$ \\
\hline 8 & $\$ 60,014$ & $\$ 165,878$ \\
\hline 9 & $\$ 71,588$ & $\$ 197,867$ \\
\hline 10 & $\$ 84,377$ & $\$ 233,215$ \\
\hline 11 & $\$ 98,429$ & $\$ 272,056$ \\
\hline 12 & $\$ 113,795$ & $\$ 314,527$ \\
\hline 13 & $\$ 130,527$ & $\$ 360,772$ \\
\hline 14 & $\$ 148,676$ & $\$ 410,937$ \\
\hline 15 & $\$ 168,299$ & $\$ 465,173$ \\
\hline 16 & $\$ 189,451$ & $\$ 523,635$ \\
\hline 17 & $\$ 202,085$ & $\$ 558,556$ \\
\hline 18 & $\$ 215,067$ & $\$ 594,438$ \\
\hline 19 & $\$ 228,405$ & $\$ 608,483$ \\
\hline 20 & $\$ 242,107$ & $\$ 617,975$ \\
\hline 21 & $\$ 256,181$ & $\$ 627,616$ \\
\hline 22 & $\$ 261,361$ & $\$ 637,406$ \\
\hline 23 & $\$ 265,438$ & $\$ 647,350$ \\
\hline 24 & $\$ 269,579$ & $\$ 657,449$ \\
\hline 25 & $\$ 273,785$ & $\$ 667,705$ \\
\hline 26 & $\$ 278,056$ & $\$ 678,121$ \\
\hline 27 & $\$ 282,393$ & $\$ 688,700$ \\
\hline 28 & $\$ 286,799$ & $\$ 699,443$ \\
\hline 29 & $\$ 291,273$ & $\$ 710,355$ \\
\hline 30 & $\$ 295,816$ & $\$ 721,436$ \\
\hline
\end{tabular}


Table 34. Adjusted and unadjusted annual WTP

\begin{tabular}{|c|c|c|c|}
\hline Year & $\begin{array}{l}\text { Unadjusted } \\
\text { WTP ha }^{-1} \\
(2017 \text { \$) }\end{array}$ & $\begin{array}{l}\text { Coral } \\
\text { Index }\end{array}$ & $\begin{array}{l}\text { Adjusted } \\
\text { WTP ha }^{-1} \\
(2017 \text { \$) }\end{array}$ \\
\hline 0 & & & \\
\hline 1 & 0.17 & 5.53 & 0.01 \\
\hline 2 & 0.18 & 7.06 & 0.01 \\
\hline 3 & 0.18 & 9.63 & 0.02 \\
\hline 4 & 0.18 & 12.61 & 0.02 \\
\hline 5 & 0.18 & 15.99 & 0.03 \\
\hline 6 & 0.19 & 19.76 & 0.04 \\
\hline 7 & 0.19 & 23.94 & 0.05 \\
\hline 8 & 0.19 & 28.52 & 0.05 \\
\hline 9 & 0.20 & 33.50 & 0.07 \\
\hline 10 & 0.20 & 38.87 & 0.08 \\
\hline 11 & 0.20 & 44.65 & 0.09 \\
\hline 12 & 0.20 & 50.83 & 0.10 \\
\hline 13 & 0.21 & 57.41 & 0.12 \\
\hline 14 & 0.21 & 64.38 & 0.14 \\
\hline 15 & 0.21 & 71.76 & 0.15 \\
\hline 16 & 0.22 & 79.54 & 0.17 \\
\hline 17 & 0.22 & 83.54 & 0.18 \\
\hline 18 & 0.22 & 87.54 & 0.20 \\
\hline 19 & 0.23 & 91.54 & 0.21 \\
\hline 20 & 0.23 & 95.55 & 0.22 \\
\hline 21 & 0.24 & 99.55 & 0.23 \\
\hline 22 & 0.24 & 100.00 & 0.24 \\
\hline 23 & 0.24 & 100.00 & 0.24 \\
\hline 24 & 0.25 & 100.00 & 0.25 \\
\hline 25 & 0.25 & 100.00 & 0.25 \\
\hline 26 & 0.25 & 100.00 & 0.25 \\
\hline 27 & 0.26 & 100.00 & 0.26 \\
\hline 28 & 0.26 & 100.00 & 0.26 \\
\hline 29 & 0.27 & 100.00 & 0.27 \\
\hline 30 & 0.27 & 100.00 & 0.27 \\
\hline
\end{tabular}




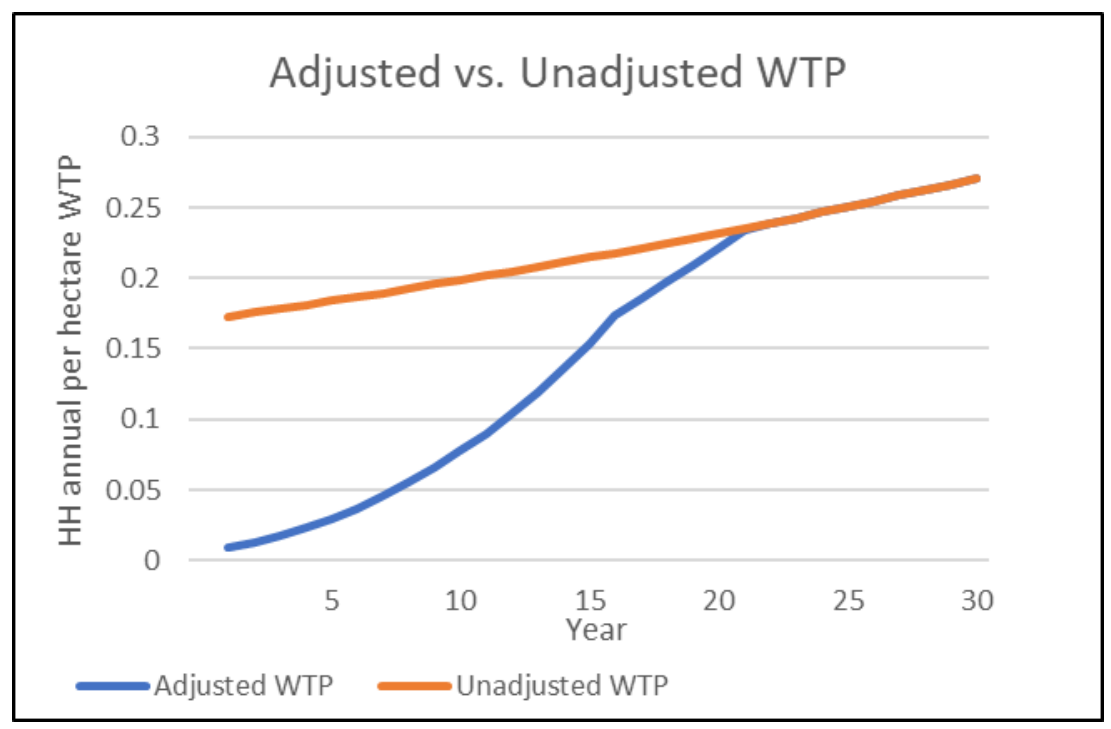

Figure 8. Adjusted. vs. unadjusted WTP

Table 35. Discounted NPV for 5 hectares annually for 30 years aggregated to various populations

\begin{tabular}{llllll}
\hline Program & $\begin{array}{l}\text { Certified } \\
\text { Florida } \\
\text { divers }\end{array}$ & $\begin{array}{l}\text { South FL } \\
\text { HH }\end{array}$ & Florida HH & SE US HH & $\begin{array}{l}\text { South FL } \\
\text { coral users }\end{array}$ \\
\hline Restocking & $2,247,091$ & $22,550,093$ & $65,165,430$ & $124,695,951$ & $10,551,742$ \\
Combined & $5,845,497$ & $58,660,947$ & $169,518,852$ & $324,379,268$ & $27,448,896$ \\
\hline
\end{tabular}

Table 36. Benefit-cost ratios: 5 hectares annually for 30 years

\begin{tabular}{lccccc}
\hline Scenario & $\begin{array}{c}\text { Florida } \\
\text { divers }\end{array}$ & $\begin{array}{c}\text { South FL } \\
\text { HH }\end{array}$ & $\begin{array}{c}\text { Florida } \\
\text { HH }\end{array}$ & $\begin{array}{c}\text { SE US } \\
\text { HH }\end{array}$ & $\begin{array}{c}\text { South } \\
\text { Florida } \\
\text { Coral }\end{array}$ \\
\hline Restocking & 0.66 & 6.66 & 19.25 & 36.84 & 3.12 \\
$\begin{array}{l}100 \% \text { increase in } \\
\text { restoration costs }\end{array}$ & 0.33 & 3.33 & 9.63 & 18.42 & 1.56 \\
$\begin{array}{l}100 \% \text { increase in } r \\
\text { Combined }\end{array}$ & 0.34 & 3.44 & 9.94 & 19.01 & 1.61 \\
\hline
\end{tabular}




\section{References}

Adey, W.H., 1978, Coral Reef Morphogenesis: A Multidimensional Model. Science 202:831-837.

Adey, W. H., Burke, R. B., 1977. Holocene Bioherms of Lesser Antilles - Geologic Control of Development. In: Frost, S. H., Weiss, M. P., Saunders, J. B. (eds.) Reefs and Related Carbonates. American Association. Petroleum Geologists. Tulsa, Oklahoma, pp. 67-81.

Ault, J.S., Bohnsack, J.A., Meester, G., 1998. A retrospective (1979-1995) multispecies assessment of coral reef fish stocks in the Florida Keys. Fish. Bull. 96(3): 395-414.

Bender, M. A., Knutson, T. R., Tuleya, R. E., Sirutis, J. J., Vecchi, G. A., Garner, S. T., Held, I. M. 2010: Modeled Impact of Anthropogenic Warming on the Frequency of Intense Atlantic Hurricanes. Science. 327, 454-458, doi:10.1126/science.1180568.

Bhat, M., 2002. Application of Non-Market Valuation to the Florida Keys Marine Reserve Management. Journal of Environmental Management. 67, 315-325.

Bohnsack, J.A. 1999. Incorporating no-take marine reserves into precautionary management and stock assessment. In: Providing Scientific Advice to Implement the Precautionary Approach Under the Magnuson-Stevens Fishery Conservation and Management Act. Restrepo, V.R. (Editor). NOAA Technical Memorandum NMFSF/SPO-40. Pp. 8-16.

Conrad, J., 1999. The Bioeconomics of Marine Sanctuaries. Journal of Bioeconomics. 1, 205- 217.

Cooper, T.F., Gilmour, J.P., Fabricius, K.E., 2009. Bioindicators of Changes in Water Quality on

Coral Reefs: Review and Recommendations for Monitoring Programmes. Coral Reefs. 28:3, 589-606.

Farrow, S., Toman, M., 1999. Using Benefit-Cost Analysis to Improve Environmental Regulations. Environment. 41:2.

Goreau, T.F., 1959. The Physiology of Skeleton Formation in Corals I. A Method for Measuring the Rate of Calcium Deposition by Corals under Different Conditions. The Biological Bulletin.

116, 59-75.

Geister, J., 1977 The Influence of Wave Exposure on the Ecological Zonation of Caribbean Coral Reefs. Proceedings of the 3rd International Coral Reef Symposium. 1, 23-29. 
Huntington, B.E., Miller, M.W., 2013. Location-Specific Metrics for Rapidly Estimating the Abundance and Condition of the Threatened Coral Acropora Cervicornis. Restoration Ecology. doi:10.1111/rec.12057.

Jackson, J.B.C., 1992, Pleistocene perspectives on coral reef community structure: American Zoologist, v. 32, p. 719-731.

Kiel, C., Huntington, B.E., Miller, M.W., 2012. Tractable Field Metrics for Restoration and Recovery Monitoring of Staghorn Coral Acropora cervicornis. Endangered Species Research. 19, 171-76. doi: 10.3354/esr00474.

Leeworthy, V.R., Bowker, J. M., 1997. Nonmarket Economic User Values of the Florida Keys/Key West. Silver Spring, MD: National Oceanic and Atmospheric Administration, Strategic Environmental Assessments Division. 41 p.

Millennium Ecosystem Assessment. 2005. Ecosystems and Human Well-Being. Washington, DC: Island Press. Available from http://www.millenniumassessment.org/documents/document.356.aspx.pdf.

Miller, S., Chiappone, M., Rutten, L.M., Swanson, D.W., 2008. Population Status of Acropora Corals in the Florida Keys. Marine \& Environmental Sciences Faculty Proceedings, Presentations, Speeches, Lectures. 486. https://nsuworks.nova.edu/occ_facpresentations/486

Mumby, P.J., Harborne, A.R., Williams, J., Kappel, C.V., Brumbaugh, D.R., Micheli, F., Holmes, K.E., Dahlgren, C.P., Paris, C.B., Blackwell, P.G., 2007. Trophic Cascade Facilitates Coral Recruitment in a Marine Reserve. Proceedings of the National Academy of Sciences 104:20 8362-8367. www.pnas.orgcgidoi10.1073pnas.0702602104.

NMFS (National Marine Fisheries Service). 2015. Recovery Plan for Elkhorn (Acropora palmata) and Staghorn (A. cervicornis) Corals. Prepared by the Acropora Recovery Team for the National Marine Fisheries Service, Silver Spring, Maryland.

Pandolfi, J. M., 2002. Coral Community Dynamics at Multiple Scales. Coral Reefs. 21, 13-23.

Pandolfi, J.M., Jackson, J.B.C., 2006. Ecological Persistence Interrupted in Caribbean Coral Reefs. Ecological Letters. 9, 818-826.

Principe, P. P., Bradley, P., Yee, S. H., Fisher, W. S., Johnson, E. D., Allen, P. Campbell, D. E., 2012. Quantifying Coral Reef Ecosystem Services. U.S. Environmental Protection Agency, Washington, DC, EPA/600/R-11/206.

Rogers, A., Blanchard, J.L., Mumby, P.J., 2014. Vulnerability of Coral Reef Fisheries to a Loss of Structural Complexity. Current Biology. 24, 1000-1005. 
Schopmeyer, S.A., Lirman, D., Bartels, E., Gilliam, D.S., Goergen, E.A., Griffin, S.P., Johnson, M.E., Lustic, C., Maxwell, K.E., Walter, C.S. 2017. Regional Restoration Benchmarks for Acropora cervicornis.” Coral Reefs 36 (2017): 1047-1057.

Selig, E.R., Bruno, J.F., 2010. A Global Analysis of the Effectiveness of Marine Protected Areas in Preventing Coral Loss. PLoS ONE 5(2): e9278.

https://doi.org/10.1371/journal.pone.0009278.

Seeteram, N., Bhat, M., Pierce, B., Cavasos, K., Die, D., Reconciling Economic Reality and Stakeholder Perception: A Management Challenge in Florida Gulf Coast Fisheries. Submitted for publication.

Southeast Fisheries Science Center (SEFSC). 2016. National Centers for Coastal Ocean Science (NCCOS). 2016. National Coral Reef Monitoring Program: Assessment of Coral Reef Fish Communities in the Florida Reef Tract. NOAA National Centers for Environmental Information. Dataset. [Accessed April 2017]

Selig ER, Bruno JF (2010) A Global Analysis of the Effectiveness of Marine Protected Areas in Preventing Coral Loss. PLoS ONE 5(2): e9278.

https://doi.org/10.1371/journal.pone.0009278

Waite, R., Burke, L., Gray, E., van Beukering, P., Brander, L., McKenzie, E., Pendleton, L., Schuhmann, P., Tompkins, E. 2014. Coastal Capital: Ecosystem Valuation for Decision Making in the Caribbean. Washington, DC: World Resources Institute. Accessible at:

〈http://www.wri.org/coastal-capital $>$. 
VITA

\section{KEVIN CAVASOS}

Born, Frankfurt, Germany

1991-1995

B.S., Finance (High Honors)

University of Florida

Gainesville, Florida

2012-2014

M.S., Agricultural and Resource Economics

University of Tennessee

Knoxville, Tennessee

2014-2019

Doctoral Candidate, Teaching Assistant

Florida International University

Miami, Florida

\section{PUBLICATIONS AND PRESENTATIONS}

Lambert, D.M., K. Cavasos, B.C. English, B. Wilson, C.D. Clark. 2016. Projected

Changes in Stream System Nitrogen Runoff Associated with a Mature Cellulosic Ethanol Industry in the Southeastern United States. Land Use Policy 56: 291-302.

"Bioeconomic Evaluation of Marine Reserve Size: Protecting Restored Coral Reefs While Maximizing Fishery Value", International Coral Reef Symposium, Honolulu, HI, 2016

"Cellulosic Biofuel Facility Locations: Location Decisions and Impacts on Surface Water Quality in the Southeastern United States", Annual Watershed Symposium, Knoxville, TN, 2014 